\title{
WHOI-86-3
}

\section{A Miniature Deep Sea Temperature Data Recorder: Design, Construction, and Use}

\author{
by
}

R. Koehler and R. P. von Herzen

\begin{abstract}
Woods Hole Oceanographic Institution
Woods Hole, Massachusetts 02543
\end{abstract}
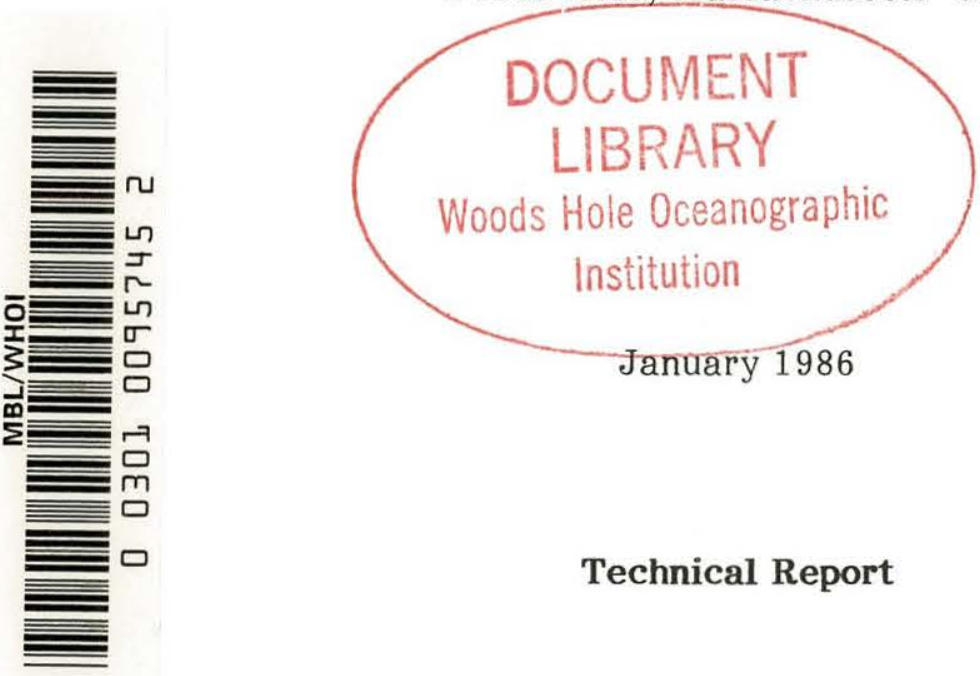

\section{Technical Report}

Funding was provided by the National Science Foundation under grant Nos. OCE 82-14658 and OCE 83-00073. Additional support was provided by U.S. Geological Survey of Woods Hole to begin development of instrumentation; and to the Ocean Industry Program of the

Woods Hole Oceanographic Institution to complete the development.

Reproduction in whole or in part is permitted for any purpose of the United States Government. This report should be cited as:

Woods Hole Oceanog. Inst. Tech. Rept. WHOI-86-3.

Approved for publication; distribution unlimited.

\section{Approved for Distribution:}

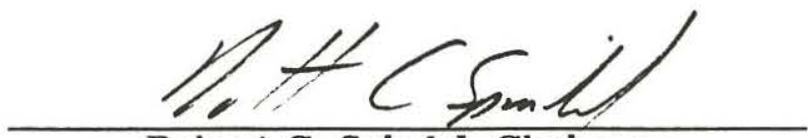

Robert C. Spindel, Chairman Department of Ocean Engineering 


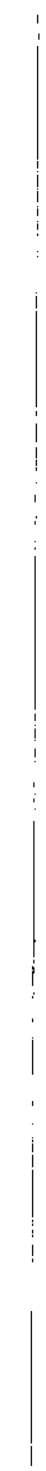




\section{LIST OF FIGURES}

\section{ABSTRACT}

I. INTRODUCTION

II. DESIGN CONSIDERATIONS 2

III. THE INSTRUMENT $\quad 4$

A. DESCRIPTION 4

B. DESIGN 4

C. CONSTRUCTION 8

D. PRINTED CIRCUIT LAYOUT 9

E. PLOTTING 11

F. BATTERIES 14

IV. CALIBRATION $\quad 15$

A. TEMPERATURE CALIBRATION

1. TEMPERATURE BATH TECHNIQUE $\quad 15$

2. LINEARITY AND SENSITIVITY 15

B. THERMISTOR CURVE FITTING TO THERMISTOR CALIBRATIONS

C. THERMAL RESPONSE TESTS OF SPECIAL HPC CORING SHOE (DSDP) 17

V. PROGRAM LOADING AND DATA HANDLING 20

A. INTERFACE BOX 20

B. DESCRIPTION OF COMPUTER PROGRAMS

VI. PERFORMANCE 23

A. EXPERIENCE IN USING THE HPC TEMPERATURE INSTRUMENT

B. EXTRAPOLATION TO EQUILIBRIUM TEMPERATURES 23

C. TEMPERATURE CALIBRATION STABILITY 31

VII. FUTURE $\quad 33$

VIII. ACKNOWLEDGEMENTS $\quad 35$

$\begin{array}{ll}\text { REFERENCES } & 36\end{array}$

APPENDIX A. CAVITY STRENGTH CALCULATIONS A-1

1. KIDNEY SHAPED CAVITY (CURRENTLY USED) A-T

2. ANNULAR CAVITY A-2

APPENDIX B. DETAILED DESCRIPTION OF THE ELECTRONICS · B-1

1. DESCRIPTION OF BLOCK DIAGRAM $B-1$

2. DETAILED DESCRIPTION OF THE SCHEMATIC (FIG. B-1) B-1 
APPENDIX C. DETAILED LIST OF INPUT/OUTPUT INSTRUCTIONS C-1

APPENDIX D. BRIDGE CIRCUIT EQUATIONS D-1

APPENDIX E. CURVE FITTING TO THERMISTOR EQUATIONS E-1

APPENDIX F. PROGRAM LISTINGS FOR THE TEMPERATURE RECORDER F-1

1. INSTRUCTIONS FOR TREC F-1

2. SOURCE CODE FOR TEMPERATURE RECORDER F-7

a. TREC $\mathrm{F}-7$

b. PLYBK F-27

c. ADTEST F-31

d. MEMTEST2 F-32

3. MACHINE CODE FOR TEMPERATURE RECORDER F-34 ( $X X X . B A S$ FILES)
a. TREC.BAS
b. AVERG.BAS
$\mathrm{F}-34$
c. PLYBK.BAS
$F-35$
d. ADTEST.BAS
$F-36$
e. MEMTS2.BAS
$F-36$
$F-36$

APPENDIX G. PRO-350 PROGRAMS G-1

1. PROBASIC.BAS G-1

2. MENU.BAS G-1

3. LOADER.BAS G-2

4. LOADI.BAS G-3

5. LOAD2.BAS G-4

6. LOAD3.BAS G-5

7. LOAD3A.BAS _. : G-6

8. LOAD4.BAS : .. : G-7

APPENDIX $H . \quad$ COMPUTER PROGRAMS TO REDUCE HPC TEMPERATURE DATA 
Figure 1. Schematic configuration of dril1 ship deploying HPC during coring operations

Figure 2. Photograph of temperature recorder and battery.

The body of the recorder is $12 \mathrm{~cm}$ long.

Figure 3. Photograph of instrumentation and battery pack outside of special hydraulic piston coring (HPC) cutting shoe (2 pieces) designed to contain them.

Figure 4. Block diagram of HPC temperature recorder.

Figure 5. Configuration of printed circuit board and components used in HPC temperature instrumentation.

Figure 6. Sectional drawing of temperature instrumentation deployed in slot in wall of HPC. Dimensions given in inches.

Figure 7. Thermistor bridge divider ratio and sensitivity vs. temperature.

Figure 8. Thermal response of the instrumentation within the HPC shoe in laboratory tests with different types of materials.

Figure 9. In-situ temperature measurement on Leg 86 , site 576 , core 6 . Note small oscillations of temperature after penetration.

Figure 10. In-situ temperature measurements on Leg 86 , site 578 , core 14. Note relatively smooth thermal decay after penetration. Outlined portion of record expanded in Fig. 13 .

Figure 11. In-situ temperature measurements on Leg 86 , site $577 \mathrm{~A}$, core 6 . Note relatively disturbed record over about 2 min. after penetration then a smooth decay.

Figure 12. In-situ temperature measurements on Leg 86 , site 577 , core 8 . Note sequential decrease, then a gradual increase, of temperatures after penetration.

Figure 13. Thermal decay of HPC during core 14, hole 578, Leg 86 (see Fig. 9). Solid dots are data points fit on the theoretical curve shown.

Figure 14. Comparison of temperature calibrations of 4 instruments before and after deployment and use at sea, over dates as indicated. Differences are calculated as the later calibration subtracted from the earlier. 
Figure A-1. Flat plate model used for cavity strength calculations. A-1

Figure A-2. Cross section view of the hollow annulus. A-3

Figure A-3. Buckling pressure vs. length of cylinder, for various numbers of buckling lobes.

Figure B-1. Schematic of the temperature recorder. $\mathrm{B}-2$

Figure D-1. Thermistor bridge circuit. D-2 


\section{ABSTRACT}

A miniature temperature recorder has been developed to be used with the hydraulic piston sediment corer (HPC) on the Deep Sea Drilling Project (DSDP). The instrumentation fits into pressure-sealed slots in the wall of the HPC, allowing temperature measurements to be made simultaneously with coring operations. Temperatures from -2 to $70^{\circ} \mathrm{C}$ are measured to a resolution of about $0.01^{\circ} \mathrm{C}$. Up to 1300 13-bit measurements are recorded in random access memory (RAM), at a sampling rate ranging between $0.1 \mathrm{~s}$ to over 100 min., as specified by the operator in a program loaded into a microprocessor of the instrument. During recording the instrumentation uses about 3.5 mamp at 7.5 volts, which can be supplied for about 20 hours of operation by a custom-made pack of silver-oxide batteries. The corer is normally left motionless in the sediment for about $10 \mathrm{~min}$. to allow extrapolation of the measured temperatures to equilibrium in-situ temperature. Examples of data from DSDP Leg 86 are given. 


\section{INTRODUCTION}

Marine geothermal measurements require that the vertical temperature gradients in sediments be determined accurately. This is usually accomplished by instrumentation lowered to the sea floor from an oceanographic ship or drilling platform. Probes and cores used with oceanographic vessels are typically designed to penetrate the bottom from 1 to $10 \mathrm{~m}$, with the gradient measured by 4-7 thermal probes rigidly attached along the probe. In deep-sea drilling, instrumentation has been used to measure temperatures at intervals during drilling frequently to depths of 200-300 m (Erickson et al., 1975; Yokota et al., 1980), and occasionally to $600 \mathrm{~m}$ below the sea floor (Erickson and Von Herzen, 1978).

The much greater penetration achieved by drilling techniques provide the opportunity to investigate variability of heat flow with depth. Although many results indicate relatively constant heat flow with depth (Erickson et al., 1975; Hyndman et al., 1985), as expected for steady-state conductive thermal transfer, oceanographic studies suggest that some regions may have more complicated thermal signatures. On or near continental margins, processes such as rapid sedimentation or slumping, or bottom water temperature variations, may produce more complex or disturbed thermal profiles. Hydrothermal circulation in ocean crust is a process which dominates heat transfer over much of the youngest sea floor, and extends to sea floor as old as $80 \mathrm{~m} . \mathrm{y}$. in some ocean basins (Anderson et al., 1977). Recently it has been found that this mechanism may involve slow fluid transfer through the overlying sediments (Anderson et al., 1979; Von Herzen et al., 1982; Becker and Von Herzen, 1982). The vertical component of interstitial fluid flow will produce a distinctive temperature profile with depth different from conductive profiles, essentially a exponential curve with a depth scale which depends primarily on the rate of vertical flow. Even extremely slow rates of pore fluid flow $\left.\left(\sim 10^{-8} \mathrm{~cm} \mathrm{sec}\right)^{-1}=0.3 \mathrm{~cm} / \mathrm{yr}\right)$ have important ramifications for schemes to dispose of wastes in the sea floor, esp. radioactive wastes which must be isolated for $10^{5}$ yrs or more.

Successful in-situ measurements of temperature in Deep Sea Drilling Project (DSDP) holes began with Leg 5 in 1969. Over the past decade, measurements have been obtained at only a few depths downhole in a small fraction of the total number of holes drilled by DSDP, due to several factors:

1) Drilling objectives did not justify the additional time required by such measurements.

2) The harsh environment of the drilling operations, primarily large shocks and accelerations, rendered downhole instrumentation inoperative (this factor has been substantially reduced by development of all solid-state instrumentation (e.g. Yokota et al., 1980)).

3) Sediment physical properties did not allow measurement of equilibrium temperatures (either too soft to hold the measurement probe steady, or too hard to penetrate).

4) Sediments are thermally disturbed due to drilling. 
The successful development of a DSDP hydraulic piston corer (HPC) has allowed retrieval of remarkably undisturbed sediment cores to depths of 200 to $300 \mathrm{~m}$ beneath the sea floor. The HPC is a nearly ideal vehicle for an in-situ temperature sensor because it deploys well below (up to $10 \mathrm{~m}$ ) the drilled and thermally disturbed hole for core retrieval (Fig. 1). Furthermore, its almost continuous deployment for the upper several hundred meters of sediments on many DSDP holes provides the opportunity to obtain detailed depth profiles of temperature with little or no cost in additional ship time.

Here we describe, in detail, instrumentation developed to obtain in-situ temperature during deployments of the HPC, along with examples of data. The instrumentation was first used on DSDP Leg 86 in 1982 (Horai and Von Herzen, 1985) and extended through the drilling program carried out on D/V GLOMAR CHALLENGER. Its use presently (January 1986) continues with the Ocean Drilling Program from D/V JOIDES RESOLUTION.

\section{DESIGN CONSIDERATIONS}

The HPC (hydraulic piston corer) is up to $10 \mathrm{~m}$ long and about $9 \mathrm{~cm}$ diameter (Anonymous, 1984). The most useful location of the temperature sensor is in the cutting shoe (the tip of the coring tool) where it is farthest from the temperature disturbances of the drill bit. Also, the tip of the coring tool is thinner than the rest of the core barrel, which suggests that it takes less time to reach equilibrium temperature with the sediment. The temperature recorder electronics could be anywhere, as long as it did not impede the operation of the coring tool.

Initially, we considered putting the electronics in a hollow (doughnut shaped) cylinder at the top of the coring tool, and running the sensor wires down the length of the coring tool. Although the users were willing to give up $15 \mathrm{~cm}$ of coring length for the electronics at the top of the core barrel, we could not determine how to run the sensor wires past the threaded sections of the coring tool to the sensor in the tip.

The cutting shoe has a $1.43 \mathrm{~cm}$ thick wall. If a portion of that wall could be hollowed out to make room for the electronics, then the sensor wires could be connected directly to the temperature recorder. If the electronics were contained on a hybrid circuit, they could be put into a space no larger than an ordinary large integrated circuit package. The $\$ 8000$ for the hybrid circuit layout and masks plus $\$ 1800$ for each unit produced were reasonable costs.

Engineers at DSDP designed as large a cavity as possible in the coring shoe to hold a very small electronics package and withstand the 10,000 psi pressure at the bottom of the 21,000 ft drill string. The modified coring shoe evolved in steps. Initially, the cavity was to be covered by a lid on the outside of the coring tool, but the possibility existed for loosening of the cap and jamming inside the drill string. The second version had the top and the bottom of the coring shoe separate, exposing the cavity for the electronics. The two sections were bolted together and 0-ring seals kept the water and pressure out of the cavity. The strength of the bolts was 


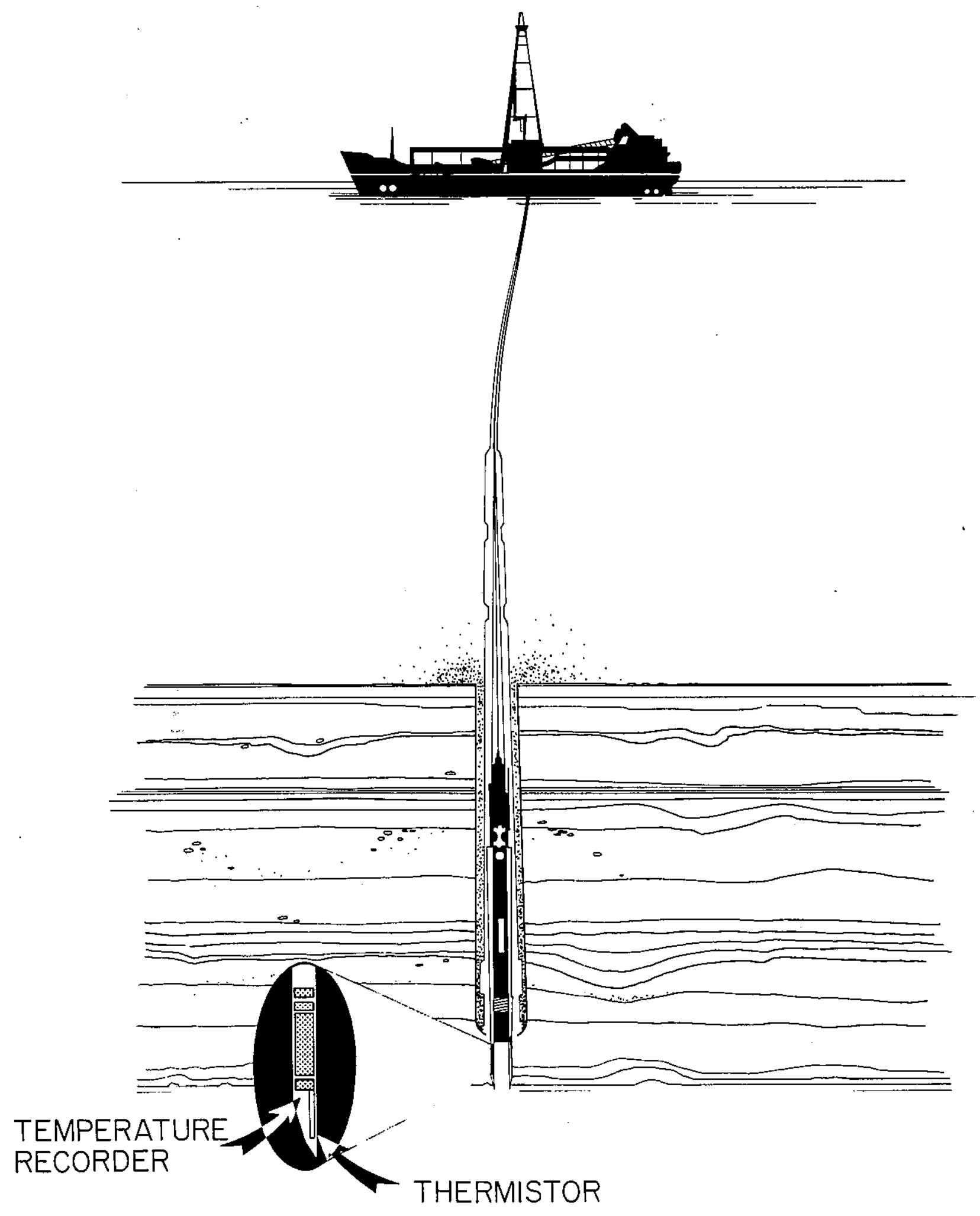

Figure 1. Schematic configuration of drill ship deploying HPC during coring operations 
determined as insufficient to withstand the side forces the coring shoe could encounter. The third version replaced the bolted fastening with a threaded section. The strongest heat treatable steel available was used for the shoe, so that the cavity could be as wide as possible. (See Appendix A for the calculation of the strength of the cavity walls.)

The instrumentation was designed to record temperatures up to $70^{\circ} \mathrm{C}$. It also had to survive the shocks encountered during the traverses of the drill string at high speed $(200 \mathrm{~m} / \mathrm{min})$, which we estimated at approximately $5000 \mathrm{~g}$ (equivalent to a free-fall of $5 \mathrm{ft}$. stopped in $0.01 \mathrm{in.}$ ). The hybrid could withstand these shocks, and the rest of the printed circuit board was potted to keep the parts from moving and breaking off the printed circuit board.

\section{THE INSTRUMENT}

\section{A. DESCRIPTION}

The temperature recorder can make and store 1300 temperature measurements and occupies $16 \mathrm{~cm}^{3}\left(1 \mathrm{in}^{3}{ }^{3}\right)$. The battery was designed to last from 35 to 50 hours (active, the lesser amount when cold) to 400 hours (data stored mode). It occupies only $10 \mathrm{~cm}^{3}\left(0.6 \mathrm{in.}^{3}\right.$ ) (see Fig. 2). Initially, the recorder is coupled to a small computer and its program is loaded each time before use. Up to 8 time delays and recording rates can be inserted, although only one is normally used.

After the program is loaded, and the recording parameters selected, the two halves of the coring shoe are screwed together (Fig. 3). The electronics and battery package are sealed from ocean pressures and water by 0 -ring seals. The coring shoe is taken to the drilling platform where it is attached to the bottom of the hydraulically driven piston corer. A tilt switch within the battery package activates the timing of the recorder when the shoe and coring tool are lifted to vertical (with the cutting edge pointing down).

The corer is lowered to the bottom of the drill string, driven into the sediment, and held there for about 5 to 10 minutes. The corer is pulled to the top of the drill string and the core and core shoe are removed. In the lab the coring shoe is opened, and a plug from the computer connected to the temperature recorder. The data are read into the computer over an RS-232C (teletype) line. The computer stores the 1300 temperature points on tape or a disk. The data, which are in raw form, can be converted to actual temperatures and stored or plotted. Also, an algorithm to determine the in situ bottom core temperature can be applied, by extrapolating the asymptotic behavior of the temperature measurements. A personal computer used to communicate with the temperature recorder is less expensive than constructing a special unit to store and process the data.

\section{B. DESIGN}

The temperature recorder block diagram is shown in Figure 4 . A thermistor in a wheatstone bridge provides voltage for an analog-to-digital 


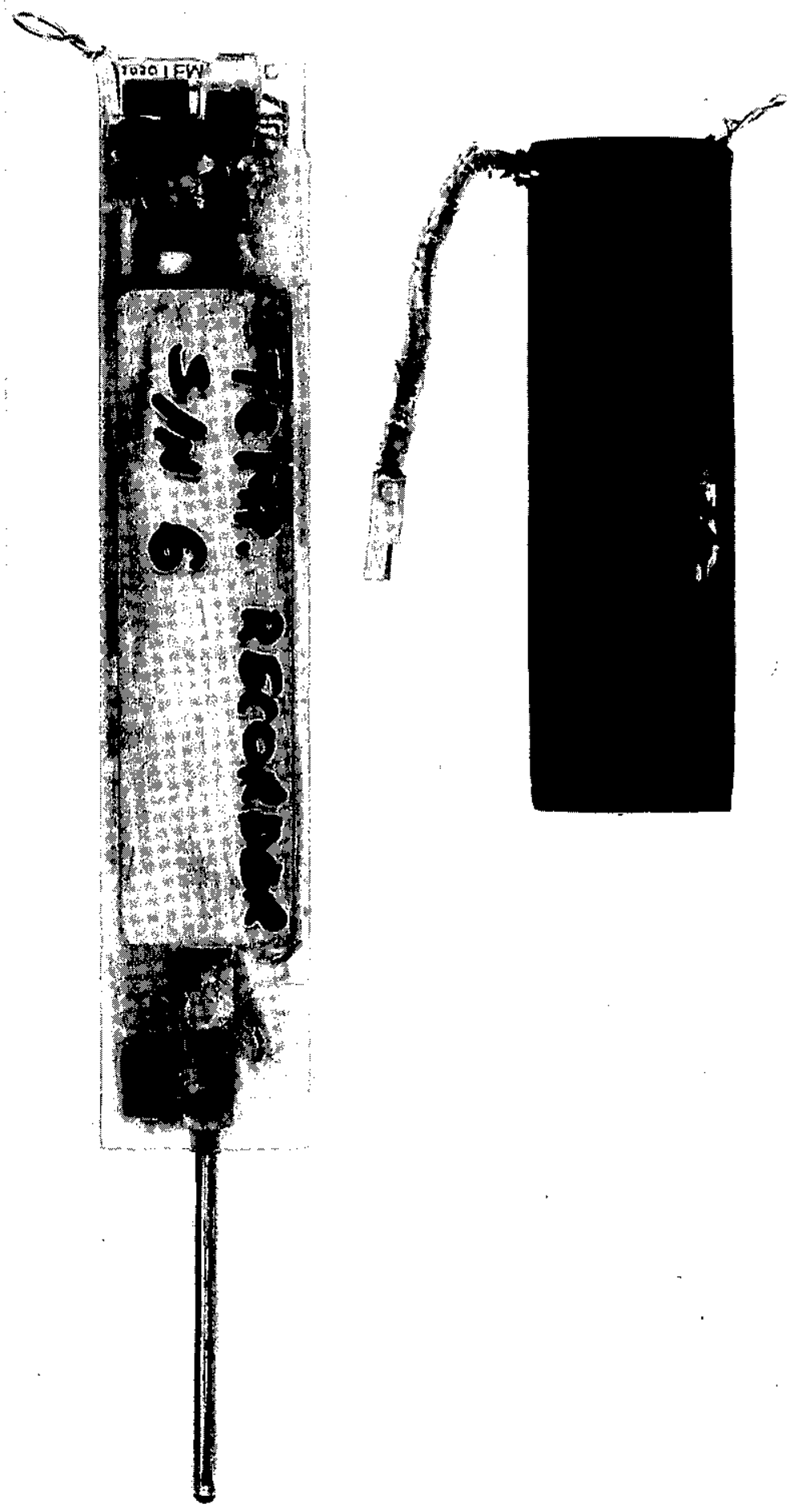

Figure 2. Photograph of temperature recorder and battery. The body of the recorder is $12 \mathrm{~cm}$ long. 


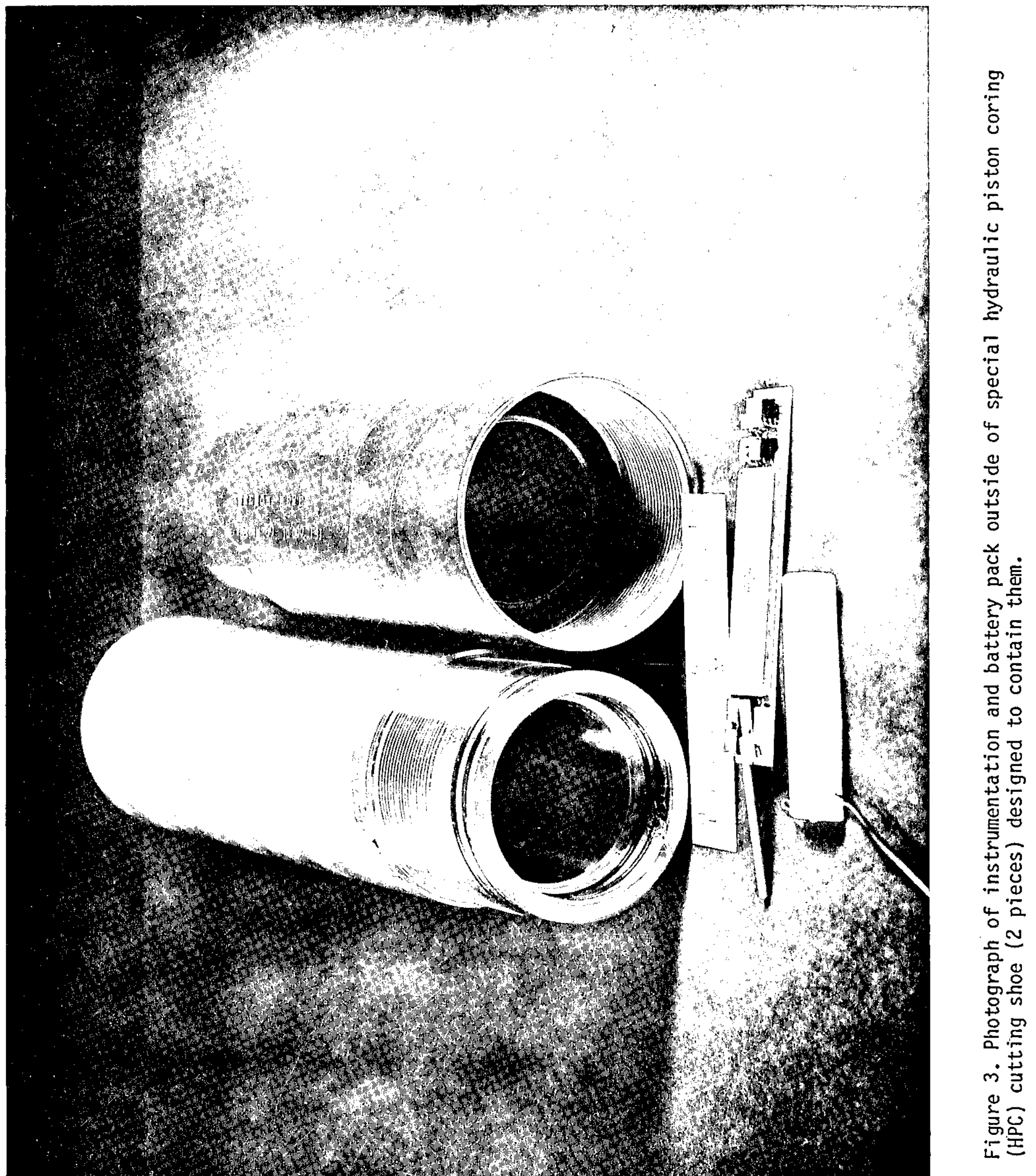




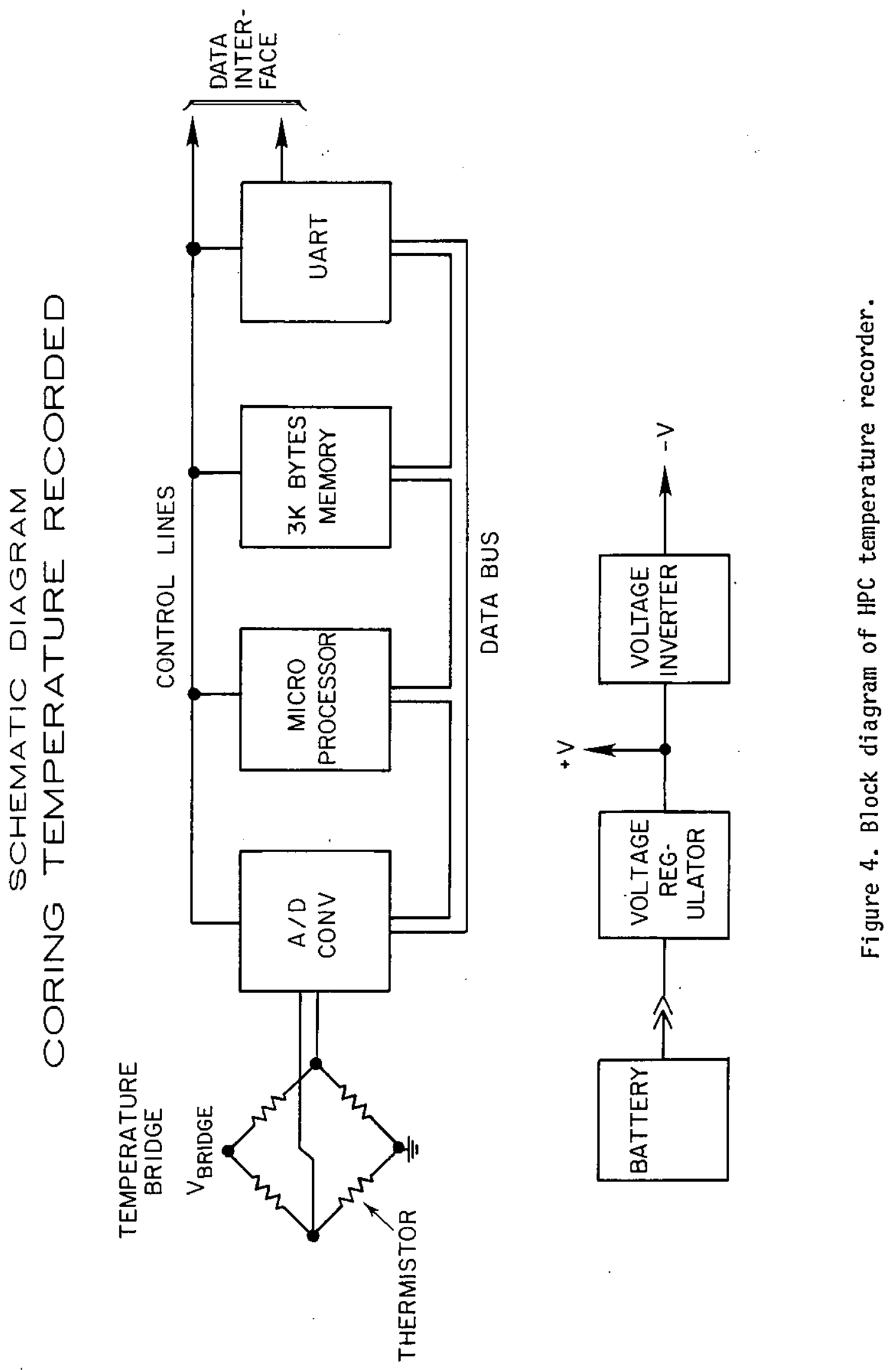


(A/D) converter. An RCA 1802 microprocessor is used to couple the output of the A/D converter to random access memory (RAM). The microprocessor also controls when the A/D converter takes a measurement. There are $3 \mathrm{~K}$ bytes of memory; about $0.5 \mathrm{k}$ are used for the program and the rest is used to store data. A universal asynchronous receiver transmitter (UART) is used to couple the computer to a teletype type output and input.

The input instructions are transferred through the UART to the computer. The program and answer to inquiries are transferred from the computer through the UART to the microprocessor and its memory.

A voltage regulator provides the +5 volts for the digital and analog circuitry. A voltage inverter provides -5 volts used only by the A/D converter. Five silver oxide hearing aid batteries provide 8 volts to the voltage regulator. To save energy, the voltage to the A/D converter is switched on only when it is being used. To save additional energy, when the data memory is filled, the voltage is dropped to 4 volts, and the microprocessor halts.

After the recorder is brought back to the surface, the coring shoe is opened up in the lab to gain access to the recorder electronics. The recorder is plugged into the on-deck computer, the recorder voltage is raised to 5 volts and the microprocessor on the recorder is started up again. The internal program then dumps the data out, stops the microprocessor and lowers the recorder voltage to 4 volts when completed. Because of the low standby power drain, the battery does not have to be disconnected. In operation at sea, the entire unit has to be removed each time so that the o-ring seals and the threaded opening to the electronics can be cleaned of mud, grease, and any dirt which may have accumulated during the deployment.

\section{CONSTRUCTION}

The circuitry had to be made quite small in order to fit into the small space available. A hybrid circuit is very small in size, and can be made relatively economically in small quantities. The first question for a hybrid circuit is determining whether it will be a thick or thin film hybrid. All hybrids are made on a ceramic substrate, typically .025 in. thick. A thin film hybrid is a single layer of gold lines placed on the ceramic through a mask. Since such a technique does not allow for wiring crossovers, the circuit cannot be very complex. A thick film hybrid consists of alternate layers of gold lines and glass insulator on a ceramic substrate. Each layer is silk screened on and the pattern is fired before the next layer is applied. Interconnections between the wires on different layers are made through holes ("vias") in the insulating layers. Because of the multiple layers, multiple cross-overs are possible to accommodate a more complex circuit. The complexity of this circuit, which used 20 integrated circuits, required a thick film hybrid circuit.

The second problem was finding a hybrid manufacturer who was willing to manufacture only a few (5-10) units. There was a fairly large engineering effort in laying out the circuit, and sources for just a few of each type of integrated circuit had to be found. Larger hybrid companies preferred to use 
their limited engineering expertise on products with a larger production. Even the smaller company we found (Transistor Specialities, Inc, Danvers, Mass.) accepted the job with reluctance, but then was determined to do the job, even though it was more complicated ( 5 metalization layers) than his colleagues in other companies thought prudent.

The design at first incorported two 40-pin packages (0.6 in. spacing between pin rows, 2 in. long) to hold the circuitry. Later the package manufacturer came out with a 3 -in.-long package with pins on 0.6 in. spacing. It was long enough to hold the whole circuit, except, for certain large parts. This simplified the printed circuit, since no connections would now be needed between two hybrid packages. We were fortunate that someone else underwrote the tooling for this larger package, as a die designed for a new package costs around $\$ 14 K$. Additional costs would be incurred for the lid die and the solder preform die.

The circuit had to be designed for integrated circuits that are available in dice form. Not only does the manufacturer need to have them available in dice form, but the dice distributer must be willing to stock the part. They are not very interested if the part is not in great enough use to allow them to sell the minimum order from the manufacturer. For RCA this minimum is one wafer of dice. For others it might be 100 pieces, even though the piece costs $\$ 100$ each. Japanese manufacturers did not seem to be interested in selling dice at all. Buying small numbers of dice is a problem. The designer must consider what is available in small numbers, or be willing to purchase more dice than needed. We even designed for one part that later was discontinued at the time of purchase. Fortunately, the hybrid had been inadvertently layed out for a larger equivalent part that was still available. Also, lead times were long, and slower moving items are not manufactured frequently.

After the hybrid is manufactured, it must be tested without physically disturbing the circuit very much. A single bond wire can be gently raised from the substrate with only a modest chance of ruining the $I C$; the entire IC can be replaced with a greater chance of ruining the whole hybrid. Generally only the hybrid manufacturer can electrically probe the hybrid. It was not difficult to determine if the circuit was working incorrectly. Ingenuity was required to devise tests to determine what part was at fault, without removing any of the parts.

Ultimately, we solved all the problems, but it was considerably more difficult than working with a printed circuit. The circuit should be designed so that faults can be isolated. The most difficult problem is designing a technique for determining which of the several ICs fastened to the same lead is at fault.

\section{PRINTED CIRCUIT LAYOUT}

We wanted to put all the components inside the hybrid in order to minimize the size of the package. However, a few parts were left out of the hybrid either because they were too large to fit, there was insufficient space in the hybrid package for them, or we wanted to be able to change them 


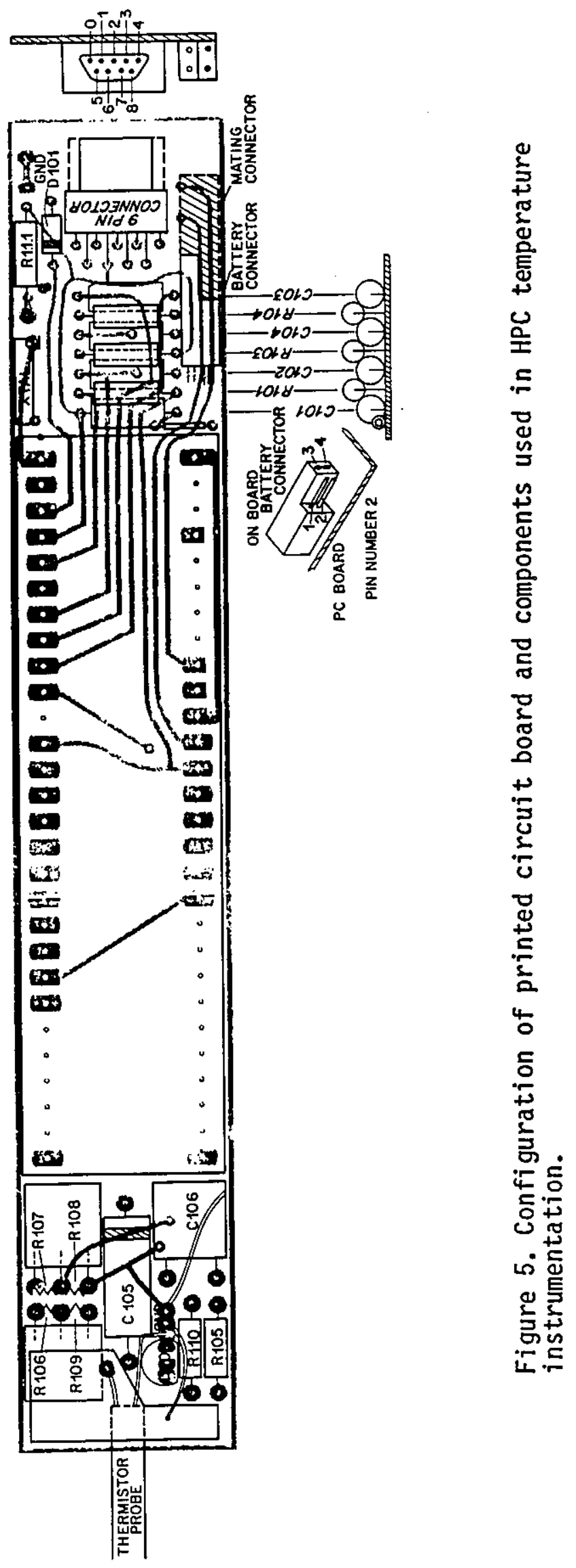


after the hybrid was built. Means were needed to connect the hybrid pins to these parts, to the temperature sensor and to the connectors for power and communication. The usual method for interconnecting parts, a printed circuit, was used (Fig. 5). It was unusual in that it was very thin, only 1/64 in. thick, in order to use as little space as possible.

The bridge components and the $A / D$ integrating and zero offset capacitors were placed at one end of the printed circuit. The hybrid package was placed in the middle. A thin (.008 in.) insulating sheet of fiberglass-epoxy board was placed between the metal hybrid package and the printed circuit. On the other end were the tantalum bypass capacitors, crystal; voltage regulator resistors, A/D frequency resistor, the data/control connector, and the battery connector.

Initially, the circuit runs were wide (0.32 in.) and the spaces between them thin (.010 in.), with the idea that the lines could be robust and the spaces between the lines did not have to be very strong. This spacing proved to be too close. The etching was not complete in several places, and fine hairs of solder from the edges of the traces could easily bridge the gaps between the lines. After an initial run of several instruments, the circuit board was layed out again to accommodate some changes, and the opportunity was used to make the traces and spaces between them equal. The board was changed to accomodate some smaller packaged bridge resistors (two to a package instead of one), an external voltage regulator for the bridge, and centering of both the large integrating capacitor and the communication connector. The centering made use of the larger clearance available in the center of the kidney-shaped hole into which the package was placed (Fig. 6). Initially, it was supposed that the thin board would bend, and the mold would force the taller components at the edge of the board inside the confines of the space available. The narrow board was quite stiff, and would not bend much. This stiffness was actually a blessing, because this board was all that really provided any stiffness to the package. This stiff board made an especially good method to secure the connector to the rest of the circuitry without flexing its soldered connections.

All parts leads were bent over parallel to the board to maximize packing efficiency. Even so, some of the leads were .025 in. thick, about $10 \%$ of the available height. The bending of leads also provided for a stronger connection, since the board was so very thin.

\section{E. POTTING}

Very large shocks to the electronics package were anticipated as it travelled down the drill pipe. Similar problems had been solved by enclosing everything in a semi-rigid potting material. The rigidity of the potting material kept the parts from being ripped from place by their own inertia during shock. Some flexibility is desirable to prevent the parts from being broken or leads sheared from the slight differences in thermal expansion between the potting material and the items being potted. A reported high failure rate of hermetically sealed tantalum capacitors of the 1500 series caused us to examine more closely several of these capacitors. 


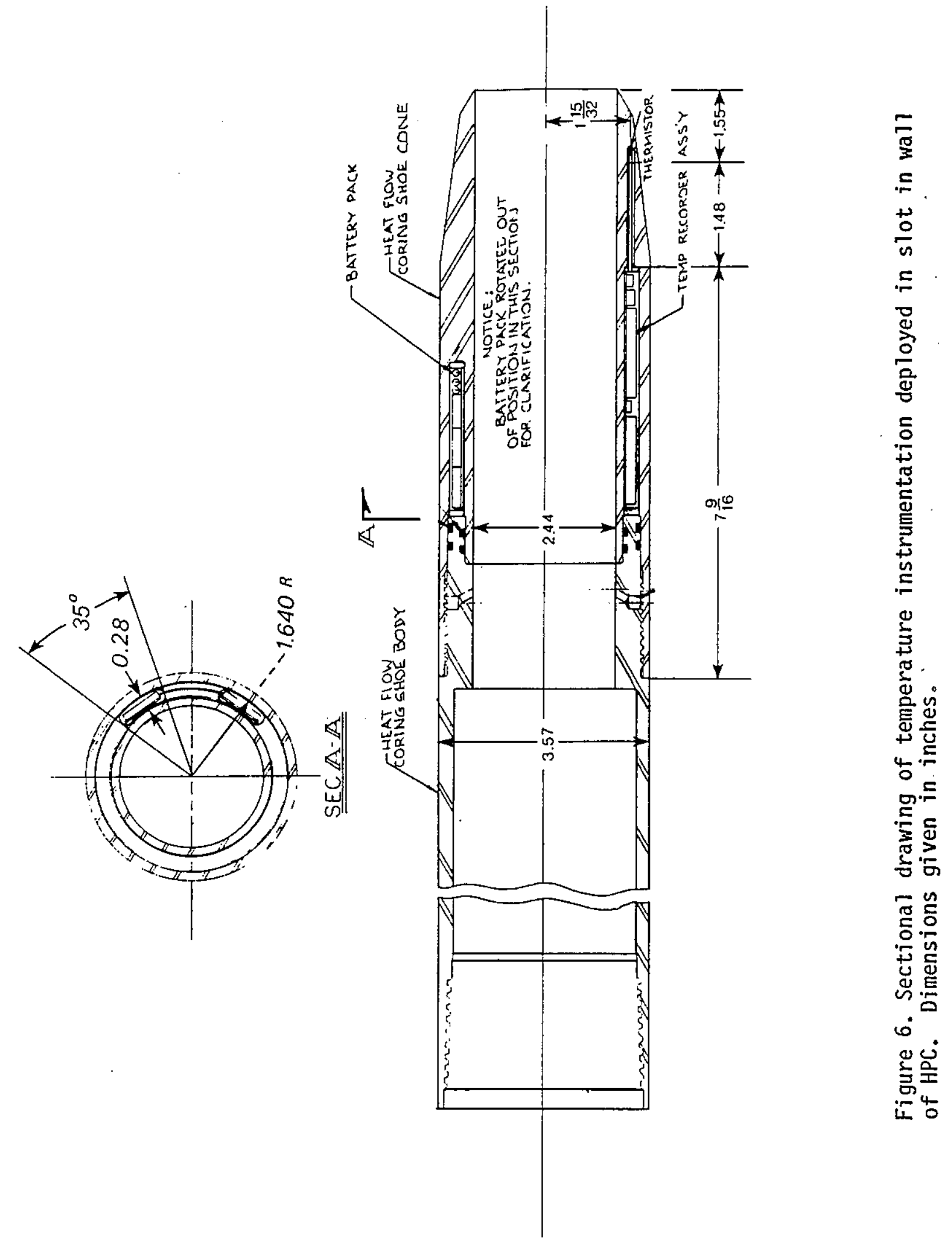


They appeared fragile with a gossamer appearance, so solid tantalum capacitors potted in epoxy were used.

Several potting materials were tried. A very hard epoxy chipped and flaked off in the thin sections, although it proved satisfactory for the battery packs, where the epoxy sections were thicker. All the slightly flexible epoxies and polyurethanes became softer and much more flexible at $70^{\circ} \mathrm{C}$. A polyurethane from CONAP (0lean, N.Y.), EN-9, was selected for this service. It too became quite flexible at $70^{\circ} \mathrm{C}$, but it remained tough.

Creating a suitable mold was one of the most difficult tasks. In an attempt to save money, we tried to take an impression of the cavity into which the electronics were to fit. We got a rubber impression, but it was flexible. Eventualiy, we got a hard epoxy impression, from which a hard polyurethane mold was made. Several electronic packages were cast which had to be sanded and filed to enable them to fit into the cavity.

Later, we received a sample cavity made of steel from the DSDP in which our molded units could be tested for fit. This test fixture was converted into a two-piece mold by cutting it in half, and replacing all but .010 inches of the cut with a shim. This solved our molding problems. A hard mold made by a mold-making shop would have cost $\$ 1,200$, which in retrospect would have been less expensive than our mistakes.

The instrument casting was made by filling the mold from the bottom, with the mold in a vertical position, which reduced the possibility of entrapped air. Because of the thin covering and bubble-prone potting techniques, the whole circuit was thinly coated with a polyurethane material (Laminar X500; Midland Div., The Dexter Corp., Hayward, CA) designed for that purpose. This would keep the circuit dry, protecting it from condensation as the package cooled off, and from accidental sea water exposure while opening up the package to read out the data. Another problem was solvent evaporating from the circuit board coating. The drying time recommended by the manufacturer of the printed circuit board coating was long enough for the coating to harden, but not long enough for all the solvent to have evaporated. The first board coating that we used worked, but we changed in mid-stream to a second type, which had the extra solvent.

The thermistor used to measure temperatures is Part No. GB42JM63 (Fenwall Electronics, Framingham, MA) with a nominal resistance of $15 \mathrm{k}$ ohms at $25^{\circ} \mathrm{C}$. It is potted within a small (0.120 in. 0.D.) tube with a high thermal conductivity silicone rubber (Eccosil 4952, Emerson and Cumming, Canton, MA). This probe is then potted in proper position with the electronics package to comprise a rigid unit.

The battery potting is done with a hard epoxy, (Stycast 2651-MM, Emerson and Cumming Co., Canton, MA), as the batteries could withstand the shrinkage forces of the setting epoxy. We first used a fairly hard rubber mold, filled from the top. A short cable with a small connector on it is used to power the electronics module. The main problem is keeping the epoxy from running out along the cable, making it stiff. The cable is given an accordian fold, to accomodate slight differences in cable length. The lack 
of stiffness in the mold was compensated for by making the package slightly thinner than the cavity. Thus clearance could exist where the battery protruded slightly into the rubber mold. Later, the steel mold for the electronics was plugged to a length of $3 \mathrm{in.}$, and used to mold the batteries.

\section{F. BATTERIES}

A cavity for the batteries in the coring shoe was placed circumferentially, rather than axially, adjacent to the electronics cavity, to minimize the length of the coring shoe. The corer takes a $10 \mathrm{~m}$ long (maximum) core and we did not want to use any more space than necessary. A cavity with the same cross section as for the electronics was used for the battery, even though it could have been a little narrower. The 3 in. length accomodated the 5 button cells. The Eveready S76E silver oxide button cell for hearing aids was chosen for the largest cell that would fit into the space available. The cell is $0.455 \mathrm{in}$. dia. $x 0.211 \mathrm{in}$. thick. A battery assembly company (Brentronics, Commack, NY) welded 5 of these together for us, with the cells side by side.

The cells have 190 mamp-hr capacity at $25^{\circ} \mathrm{C}$, and can operate at $70^{\circ} \mathrm{C}$ if not held at that temperature for too long. The electronics uses only 3.5 mamp maximum when the A/D converter is running, which should give 50 hours of life. This is more than sufficient for perhaps 20 each or more deployments to the bottom for coring and return (average time 2 hrs. each). The electronics package is opened up each time, and the battery pack can be easily replaced at the end of its life. Even longer life is achieved in the "computer running only" state with a current drain of 1.3 mamp for 140 hours (about 6 days), or in the standby mode (memory retained, computer idling) with a current of 0.4 mamp for a 475 hour life (20 days).

The operating time with the $A / D$ running, based on a 190 mamp-hr battery capacity at $25^{\circ} \mathrm{C}$, is reduced to about $35 \mathrm{hrs}\left(70 \%\right.$ capacity) at $0^{\circ} \mathrm{C}$. However, the battery pack was exhausted after only 20 hours at $0^{\circ} \mathrm{C}$, with a recorder current measured at 3.5 mamp. This was verified in the laboratory by connecting a resistor to the battery pack which would draw 3.5 mamp at 7.5 volts (the nominal battery voltage, which is nearly constant during discharge). The additional reduction to 20 hours is unexplained. It could be caused by old batteries, which have reduced life, or by the heat from welding tabs to such small cells. Fortunately, 20 hours is still sufficient for 8 to 10 measurements.

The battery pack includes an inexpensive tilt sensor which commences timing when the corer is lifted to the vertical position. Originally it had been placed in the electronics package, but there was insufficient space for it, and it had to be put into the battery pack.

A small 4-pin connector was used to connect the battery pack to the electronics. The cable part was fastened to the disposable battery, to eliminate any cable fatigue in the permanent electronics. 
IV. CALIBRATION

\section{A. TEMPERATURE CALIBRATION}

The temperature recorders are calibrated in a stable temperature controlled bath from 0 to $60^{\circ} \mathrm{C}$ at each $10^{\circ} \mathrm{C}$ intervals. The bath temperature is measured with a platinum resistance thermometer and bridge while the temperature recorder output is monitored with a computer. The resistance of the thermistor in the temperature recorder at each temperature point is calculated and used to fit to the thermistor equation (see below). The parameters of the thermistor equation for a particular recorder are used for calibration of the data acquired by that particular temperature recorder.

\section{TEMPERATURE BATH TECHNIQUE}

A stable temperature bath is used to control the temperature of the temperature recorders. We used a Tronac (Orem, Utah) bath, with a stability of about $2 \mathrm{~m}^{\circ} \mathrm{C}$ or better. Each temperature recorder is put into the finger of a waterproof surgeons glove and connected to a cable for plugging into the interface box. The glove and recorders are taped to a rigid plastic bar and inserted as far into the bath as the top of the glove will safely allow. A plastic bar is used because of its low heat conductivity and heat capacity. A separate ground wire is placed in the bath and connected to the ground connection (black binding post) on the interface box. This shorts out the 50 volts ac that would otherwise be in the bath and couple noise into the recorder. We calibrate all the recorders that are on hand at one time, to save the time it takes to run through the temperature range with the bath. Each recorder cable is plugged into the interface box at each temperature. Although we have not used it, a switch box would be desirable.

We started at the lowest temperature $\left(0^{\circ} \mathrm{C}\right)$ and worked up, because the bath can be heated more quickly than it can be cooled. The bath temperature was measured with a laboratory standard platinum resistance thermometer and a precision resistance bridge. Calibration of the platinum resistance thermometer is maintained in the usual way with a triple point of water cell at $0.010^{\circ} \mathrm{C}$. The two 10 turn potentiometers (coarse and fine) used to set the bath temperature on the controller have been replaced with a stable resistance box, to enable return to a given temperature setting.

The interface box was connected to an HP 85 desktop computer which both down-loaded the RCA 1802 A/D Read program into the recorder and read the recorder output and listed it on the screen. The HP 85 program, which read the recorder output, also had an option to average 50 readings, to get a better estimate of the measurement, which usually jumped between 2 and occasionally 3 least significant bits. The output of the interface box is in hexadecimal numbers in ASCII on an RS232-C line, so that any computer can be used.

\section{LINEARITY AND SENSITIVITY}

The readings from the recorder are used to determine the resistance of the thermistor at each temperature calibration point by using the 


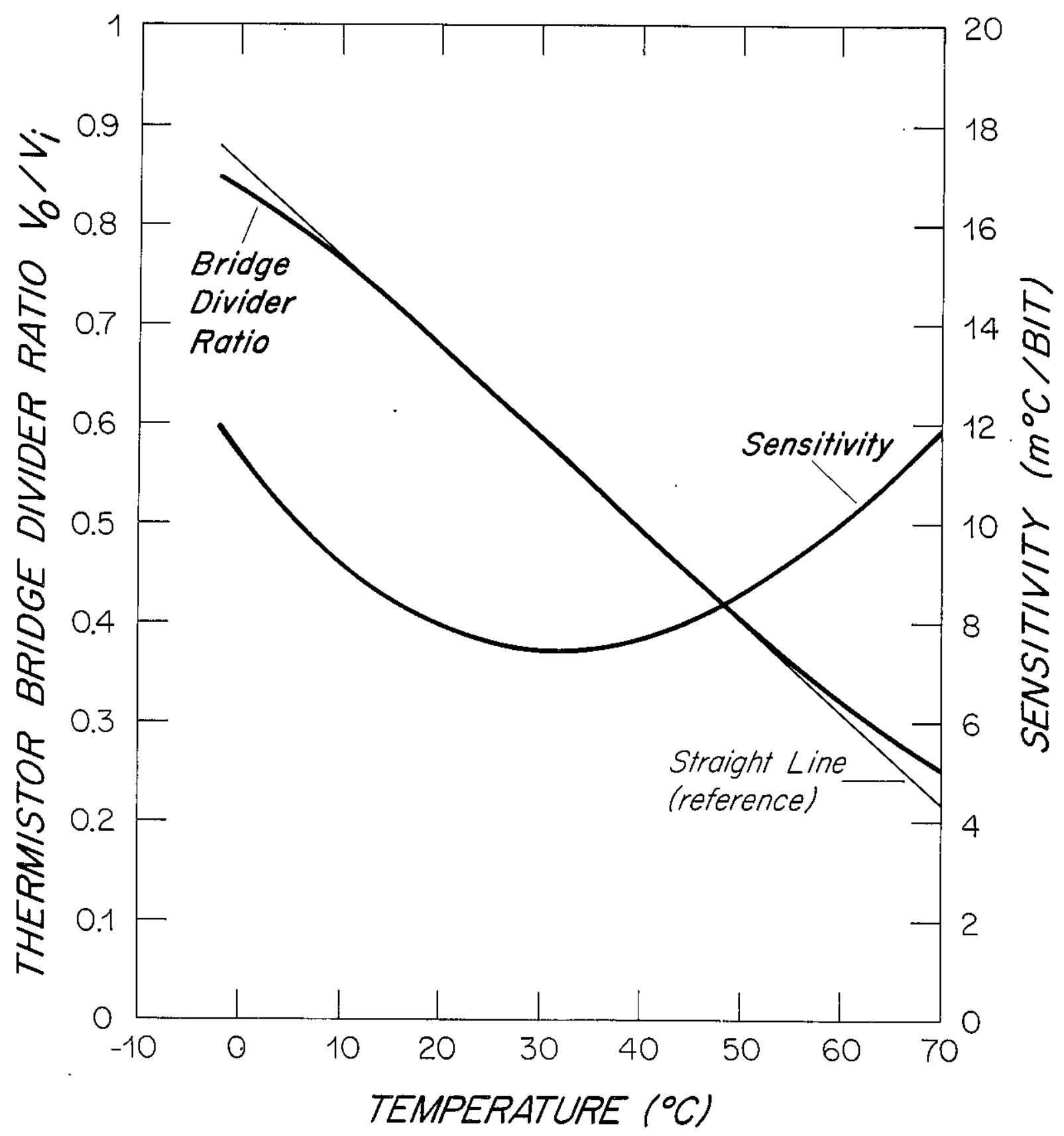

Figure 7. Thermistor bridge divider ratio and sensitivity vs. temperature. 
parameters of the $.01 \%$ accuracy resistors used in the bridge circuit for the thermistor (Fig. D-1, Appendix D). The output of a resistance bridge with a thermistor in one leg is fairly linear in temperature (see Fig. 7). This linearity keeps the sensitivity fairly uniform over the range, varying from 8 to $11 \mathrm{~m}^{\circ} \mathrm{C} / \mathrm{bit}$ for this recorder range of -2 to $70^{\circ} \mathrm{C}$. These resistance values vs. temperature are used in a least squares best fit to the steinhart and Hart equation for thermistors. The parameters of this thermistor equation are then used to convert the raw data measured by the recorder into temperature. The thermistors used in the recorders are matched to within $0.25^{\circ} \mathrm{C}$ over the 0 to $70^{\circ} \mathrm{C}$ temperature range. To optimize temperature accuracy, the thermistor calibration coefficients for each individual recorder must be used in data conversion.

The temperature recorders should be recalibrated of ten enough to keep any changes from affecting the measurements. Some calibration shifts of up to $50 \mathrm{~m}^{\circ} \mathrm{C}$ were found in 2 instruments after one year (see below). The problem was that we do not know when the calibration changed, so we do not know which data were affected. Hence, a method to check the calibration at sea is desirable. In these cases, only the calibration offset changed, not the slope, so perhaps a single point calibration would be sufficient while at sea to assure the validity of the data.

\section{B. THERMISTOR CURVE FITTING TO THERMISTOR CALIBRATIONS}

We have found that the thermistor calibrations are fit very well (to better than a few millidegrees over a $60^{\circ}$ range) by a 3 parameter equation (Steinhart and Hart, 1968)

$$
T^{-1}=A+B \ln R+C(\ln R)^{3}
$$

where $T=$ temperature $(K)$

$$
R=\text { thermistor resistance (ohms) }
$$

$A, B, C$ are constants, different for each thermistor. The constants $A, B, C$ are determined from a least squares best fit to thermistor calibration data as explained in greater detail in Appendix $E$.

\section{THERMAL RESPONSE TESTS OF SPECIAL HPC CORING SHOE (DSDP)}

The following describe tests of the thermal response of the shoe, as made in the laboratory at WHOI (January 1982) using various materials and procedures. A calibrated thermistor was placed in a $1 / 8$ in. outer-diam. steel tube, which was in turn inserted in the mating hole in the shoe designed to contain the temperature sensor. The thermistor was located about 1-1/2 in. from the cutting edge (we did not attempt to vary this distance during these tests). The thermistor was connected to a signal processor and data logger (actually a breadboard of the circuitry employed in the in-situ recording system). 
Thermal responses were obtained in 3 different materials:

1) in a well-stirred water bath

2) in gelatin

3) in clay (potter's clay).

All of these tests were carried out in a bucket of the respective materials about 10 in. diam. $x 12$ in. deep. The shoe was inserted into the middle of the materials starting at time $t=0$. The results in Fig. 8 shows the fraction $(F)$ remaining of the total temperature change for each experiment, which is calculated as $F=\frac{T_{\infty}-T(t)}{T_{\infty}-T_{0}}$

where To $=$ HPC shoe temperature before starting test

$\mathrm{T}_{\infty}=\begin{gathered}\text { temperature of medium (or bath) in which HPC shoe is } \\ \text { inserted }\end{gathered}$

$T(t)=H P C$ shoe temperature at time $t$ after start of test.

The curves in Fig. 8 show that the HPC shoe will decay to about $20-25 \%$ of its initial temperature anomaly 5 minutes after penetration. An exact determination of in-situ temperatures requires fitting of the thermal response curve to a theoretical (numerical) model (see Sec. VI.). The thermal response curves have some peculiarities which may be explained by the experimental conditions:

1. The thermal decay curve in the well-stirred water bath has an inflection between 20-30 sec when plotted on a logarithmic time scale. This may represent the thermal response of the shoe geometry. On the other hand, it may be the effect of the test conditions. The water outside of the HPC cutter is well-stirred whereas the water inside the shoe was mixed only by raising and lowering the shoe a few times during the test. This was probably first done at about $20-30 \mathrm{sec}$. after beginning this test:

2. The thermal response of the HPC in gelatin appears slightly faster than in clay, whereas the thermal conductivity of the gelatin ( 1.48 $\mathrm{mcal}{ }^{\circ} \mathrm{C}^{-1} \mathrm{~cm}^{-1} \mathrm{sec}^{-1}$, or TCU) is less than half that of the clay $(3.65$ TCU). We surmise that there may have been a thin layer of air between the HPC cutter and the clay, caused by the way in which the shoe was forced into the clay. The relatively high shear strength of the clay caused the level of clay inside the shoe to be much less than the level outside $(3-7 / 8$ in. vs. $7-3 / 4$ in., respectively, from the shoe cutting edge) during the test, whereas these level differences during the tests with gelatin were observed to be much less. (This problem would not be expected during normal use of the HPC in-situ due to the high hydrostatic pressure.)

Another possibility is that $T_{\infty}$ in the gelatin $\left(18.8^{\circ} \mathrm{C}\right)$ was measured incorrectly. It was significantly lower than that of the clay even though all tests were done in the same laboratory. It was noted after the tests that the gelatin rapidly disappeared as a result of dehydration (evaporation), perhaps causing the surface of the gelatin to have a lower temperature than the interior of the bucket used in the tests. 


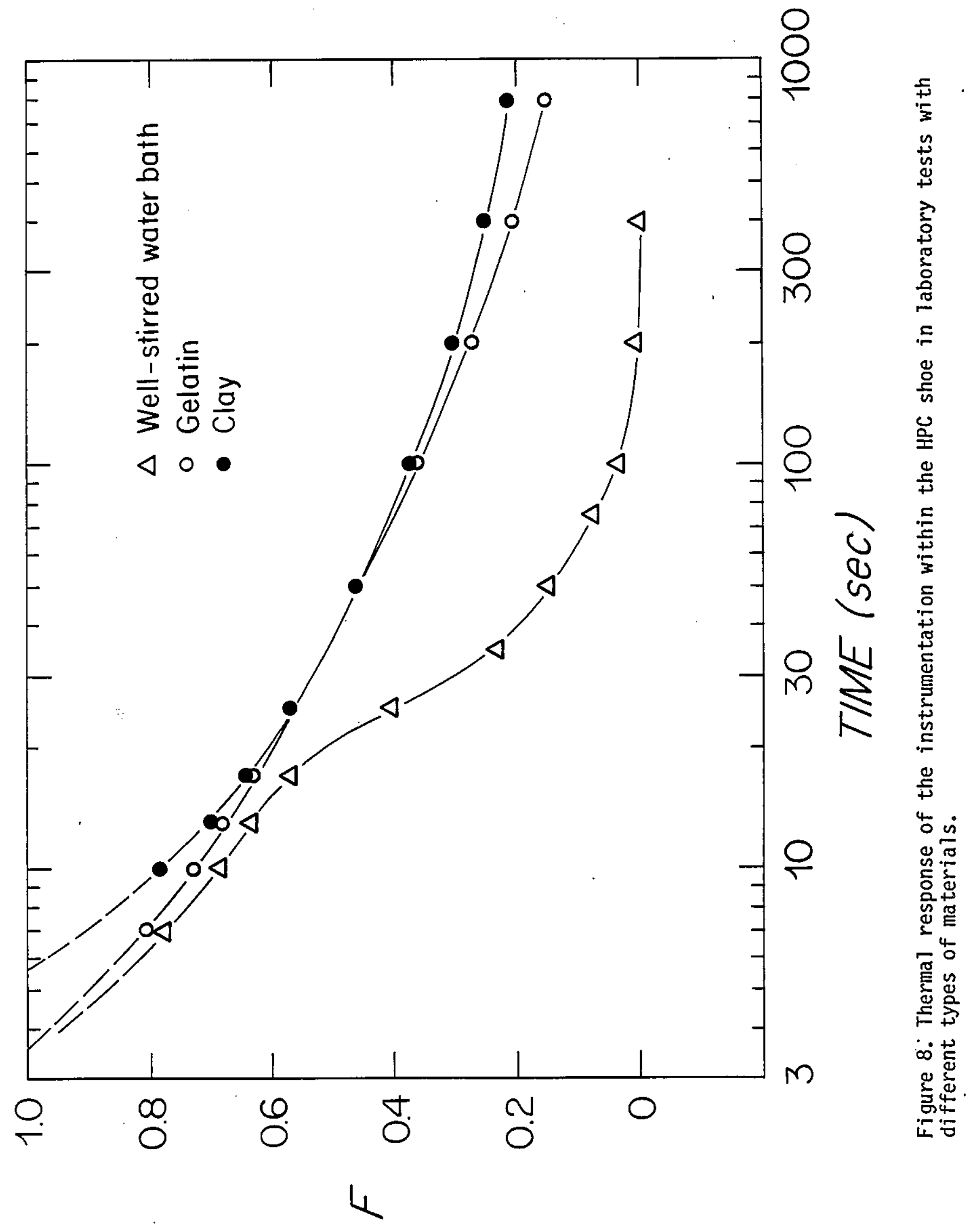




\section{PROGRAM LOADING AND DATA HANDLING}

The temperature recorder, contained within the wall of the coring shoe, can make up to about 1300 temperature measurements during coring operations, consisting of: 1) the descent of the coring tool to the bottom of the drill hole, 2) the insertion of the coring tool in the sediment (the temperature measurements that we want), and 3 ) the ascent of the coring tool to the surface. Temperature can be measured over the range from $-2^{\circ} \mathrm{C}$ to $+70^{\circ} \mathrm{C}$, with an average resolution of $9 \mathrm{~m}^{\circ} \mathrm{C}$. A time delay can be set so that the temperature recorder is near the bottom of the drill string before recording begins. The sample interval is used to spread out the 1300 measurements to bracket the time that the coring tool is in the sediment. If necessary, more than one sample interval can be used, with the faster rate in the center of the expected time in the sediment and slower rates before and after, in case the center time does not coincide with the time in the sediment. However, there is no time recorded, so that the timing of data acquisition rate changes must be deduced from the programming and accurate counting of the data.

\section{A. INTERFACE BOX}

The temperature recorder communicates through its UART with a desktop computer interfaced through the computer's RS-232 communication port. However, the UART voltages from the temperature recorder and the RS-232 voltages from the computer are different. So an interface box was designed to change the voltage levels between the temperature recorder and the interface box. The box and its cables also provide a means to connect from the subminiature 9 pin connector on the temperature recorder to the larger 25 pin RS-232 connector on the computer.

The interface box also has a manually controlled RUN/RESET/LOAD function, which controls the program load operation from the computer to the temperature recorder. The RUN function is used to communicate with the temperature recorder. The RESET function resets the microprocessor in the recorder, and resets its program counter to 0 . The LOAD function enables the recorder to load successive bytes into its memory from the RS-232 1 ine of the desktop computer. This is how the program is loaded into the temperature recorder. When the program has run and data is to be read out, the RESET function is used to set the program counter to 0 , and the data is transmitted when returned to the RUN function. This data is read by the desktop computer.

Either the PRO-350 or HP-85 computers can be selected. An HP-85 computer was used during instrument development because it was available. The HP-85 has program control of several other 1 ines in the RS-232 connector, and these lines were programmed to control the load and reset functions that have to be operated manually with the PRO-350. Therefore, there are level changing circuits in the interface box for the reset, load, and power down/ power up lines.

The circuitry of the interface box changes the +12 volts and -12 volts signals on the RS-232 line from the computer to the +5 volts and 0 volts signals of the UART in the temperature recorder. The table below describes the signals. 
Table 1. RS-232 Interface Box Connections

SIGNAL

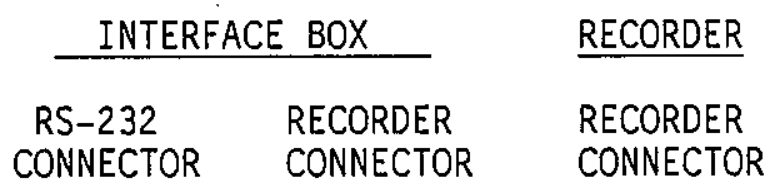

Data from desktop computer to

temperature recorder

Data from temperature recorder to desktop computer

Signal ground

+5 volts from temperature recorder

+Battery

Reset temp. recorder computer

Load temp. recorder computer

Power up (same signal as reset)

Power down
3

2

7

$-$

$-$

5

8 *

5 *

6 *
2

1

0

6

5

7

8

4

3

* Connected only when the HP-85 is selected.

The data rate is 1200 baud, determined by the temperature recorder. The RS-232 data lines use negative true logic, whereas the control lines use positive true. The recorder uses positive true logic for both data and control lines.

\section{B. DESCRIPTION OF COMPUTER PROGRAMS.}

There are two types of computer programs. One type (suffix .ASC) is run by the temperature recorder, and controls the A/D converter, sample interval, storage of data, and reading data out. These programs are written in assembly language for the RCA $1802 \mathrm{microprocessor}$ in the temperature recorder.

The other type of programs (suffix .BAS) are run by the DEC PRO-350, to load the 1802 programs into the temperature recorder, provide a terminal to interact with the temperature recorder's request for data collection parameters, and read the data from the temperature recorder, and convert the raw data to temperature. These programs can be run on other small computers by making suitable changes in the programs to accomodate the pecularities of the particular computer. The programs are written in BASIC for the DEC PRO-350. 
The PRO-350 must load the program into the recorder each time the recorder is used. The recorder has only RAM (no ROM), so the program disappears each time the power is disconnected from it. Also, part of the recording program is written over by data, when that part of the program is no longer needed, to make room for more data.

The PRO-350 programs are listed first, along with the corresponding menu item that selects them. All the programs are provided on a floppy disk, but are run from the hard disk because they need it to run during their "interim storage" phase, which is used to make room for storage of data from the recorder.

PRO 350 PROGRAMS

PROBASIC.BAS

MENU.BAS

LOADER.BAS

LOADI . BAS

LOAD2. BAS

LOAD3. BAS

LOAD3A.BAS

LOAD4.BAS
CORING TOOL TEMPERATURE

RECORDER (MENU)

program.

PROBASIC.BAS - A short instruction program for running the MENU

MENU.BAS - A program to select thermal conductivity, downhole instrument operations, or exit.

LOADER.BAS - The main operating program for downhole operations. It contains the operation menu which has 7 entries (the menu is called CORING TOOL TEMPERATURE RECORDER). The load program sub-menu and program for loading the $x x x x$.ASC programs into the temperature recorder is the first item in the menu.

Menu items 2 through 6 call the sub-programs LOADI.BAS through LOAD4.BAS respectively and menu item 7 returns to the MENU.BAS program. The following sub-programs return to LOADER.BAS when finished.

LOADI.BAS - to load operational parameters into the temperature recorder and start it running.

LOAD2.BAS - dumps data from the temperature recorder into the computer, display it to the screen, and store data to disk.

LOAD3.BAS - displays raw data for screening.

LOAD3A.BAS - prints raw data on a printer for hard copy. 
LOAD4.BAS - converts raw data files to resistance and temperature files $(x x x x . T X T)$. This program includes all the temperature recorder calibration data. The program converts the raw data, saves results to disk, and provides a hard copy on the printer.

The temperature recorder (1802) programs are loaded into the recorder by selecting item 1, LOAD PROGRAM, from the CORING TOOL TEMPERATURE RECORDER menu. The programs that can be loaded, with their corresponding menu selection and a brief description are listed below.

$\begin{array}{ll}\text { RECORDER PROGRAMS } & \text { LOAD PROGRAM (MENU) } \\ \text { MEMTS2.ASC } & \text { 1. LOAD MEMORY TEST } \\ \text { TREC.ASC } & \text { 2. LOAD MAIN PROGRAM } \\ \text { ADTEST.ASC } & \text { 3. LOAD A/D TEST } \\ \text { AVERG.ASC } & \text { 4. LOAD AVERAGING PROGRAM } \\ \text { PLYBK.ASC } & \text { 5. LOAD PLAYBACK PROGRAM }\end{array}$

MEMTS2.ASC - Used to test memory of the temperature recorder. recorder.

TREC.ASC - The main program for data acquisition by the temperature

ADTEST.ASC - This program makes A/D readings of the temperature bridge and transmits them through the UART to the desk top computer several times a second.

AVERG.ASC - A version of TREC2. ASC which averages 8 temperature measurements by the $A / D$ and stores the average.

PLYBK.ASC - This program is used to read out data from the recorder when the readout procedure built into TREC2. ASC fails.

The use of these programs is described in the "Temperature Recorder Operating Manual".

\section{PERFORMANCE}

\section{A. EXPERIENCE IN USING THE HPC TEMPERATURE INSTRUMENT}

The first and most extensive field use of the HPC instrument to date (Jan. 1986) in the Deep Sea Drilling Project was on Leg 86 in the Western Pacific (Horai and Von Herzen, 1985). The relatively large data recovery from that leg, approximately 40 downhole measurements at six different sites, was primarily due to the dedication of $K$. Horai and the DSDP staff. After the first one or two sites, during which experience was being accumulated, one person ( $K$. Horai) could maintain the instrumentation and process the data at a rate of one measurement on every other core (approximately one measurement each 3 to 4 hours). K. Horai (pers. comm., 1984) indicates that under normal operating conditions, with at least two instruments available for alternate use and preparation, one person per watch dedicated to the 
program could probably obtain measurements on every core (each $1-1 / 2$ to 2 hours) during continuous operations.

Some problems were encountered on the initial use of the instrument. The difficulties with potting materials and techniques described above led to the instruments on Leg 86 being successfully potted only immediately before they were taken to sea. These potted units did not quite fit into the slots in the core nose for which they were made, so that $K$. Horai spent several hours on each unit to trim (sand) them down to size. We are not certain why these potted units did not fit with the same mold which was successfully used to pot trial units in the laboratory. One possibility is that inclusion of the instrument within the potting reduces the amount of shrinkage because there was less potting material to shrink compared to the trial units.

Another problem on Leg 86 was that the programming of a delay time in the instruments before taking data never appeared to perform properly. Apparently ( $K$. Horai, pers. comm., 1984) the setting of a time delay in the program TREC (see appendix) resulted in arbitrary start times of the instrument, different than set up in the program. All of the successful runs on Leg 86 were made with the delay time set equal to zero, a condition which always started data acquisition soon after picking up the core barrel and initiation by the tilt switch. The failure with start times other than zero may be a software fault or operational confusion, as instruments tested in the laboratory appeared to perform properly.

During measurements at the first site of Leg 86 (site 576), it was noted that small oscillations of temperature over the period of HPC extension (approximately 5 to 10 minutes) were observed, apparently due to vertical heave oscillations of the ship (Fig. 9). It was observed that release of tension in the cable used to lower the HPC, as well as lowering the drill string 1-2 $\mathrm{m}$, resulted in much smoother thermal decay curves (Fig. 10). Apparently the cable tension is responsible for transmitting motion to the HPC when it is extended into the bottom. Also, some data appeared to be repeated over short intervals (3-4 data points), most likely a software fault in the processing of data. This problem occurred less frequently at subsequent sites.

Other characteristics of the measurements important for obtaining accurate in-situ values were observed on Leg 86 operations as well as subsequent legs. Although, in some cases, the measurement was disturbed after the initial penetration, probably as a result of drill ship motion, sometimes a good thermal decay was observed after a few minutes of disturbance (Fig. 11). It appears that the smooth thermal decay after the disturbances can be used to obtain accurate in-situ values, using numerical methods described below. Another type of measurement is illustrated in Figure 12. Here the temperature appears to decay smoothly after the initial frictional penetration pulse, but subsequently increases irregularly thereafter. This behavior typically occurred for measurements attempted in the shallower portions of holes $(\leq 100 \mathrm{~m})$, and it seems probable that the irregular temperature increases are caused by slow settling of the corer and drill string in the soft sediments. If a sufficiently long $(\geq 2 \mathrm{~min})$ undisturbed record of the thermal decay exists after penetration, reasonably accurate in-situ temperature may be obtained. 


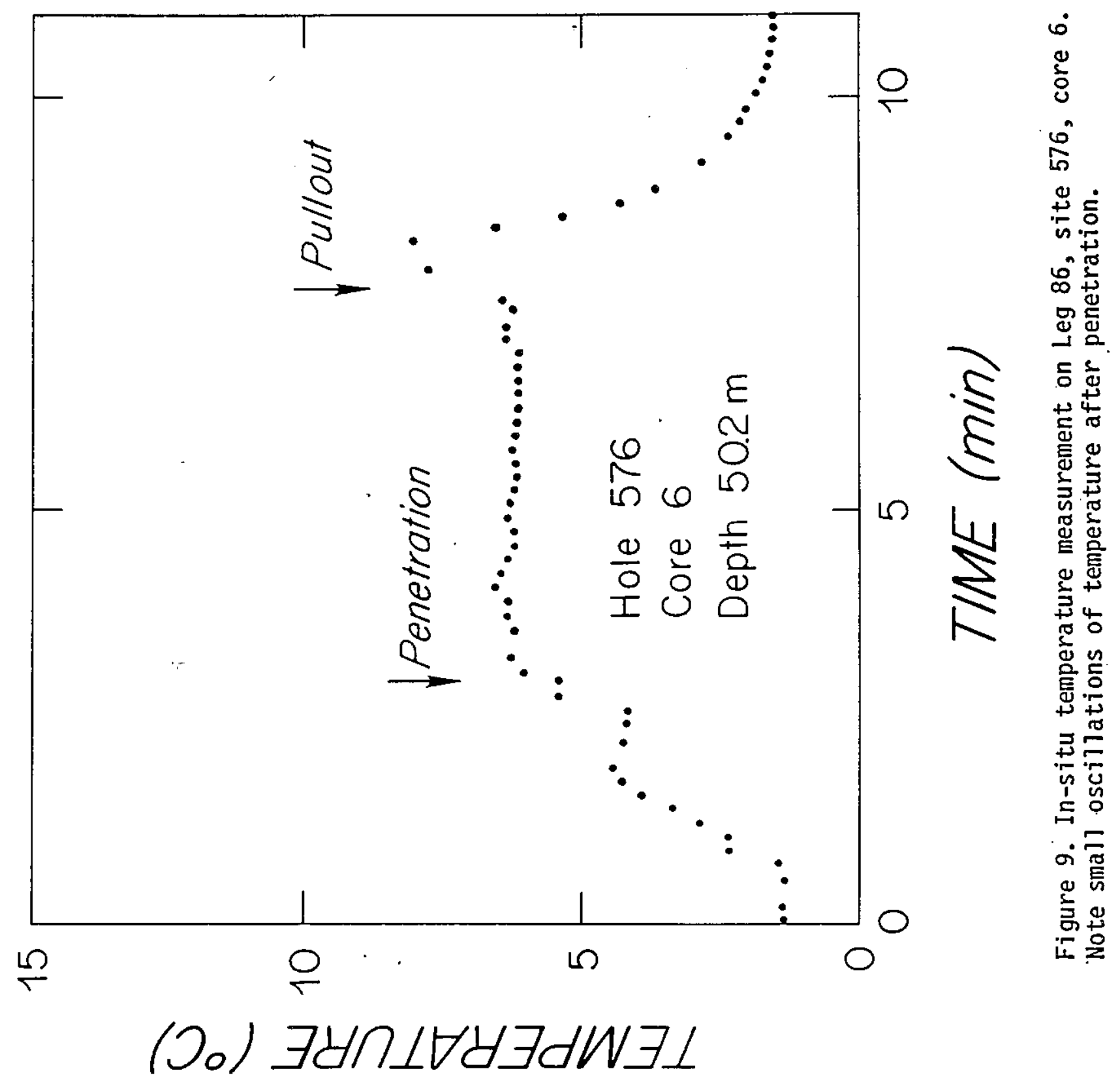




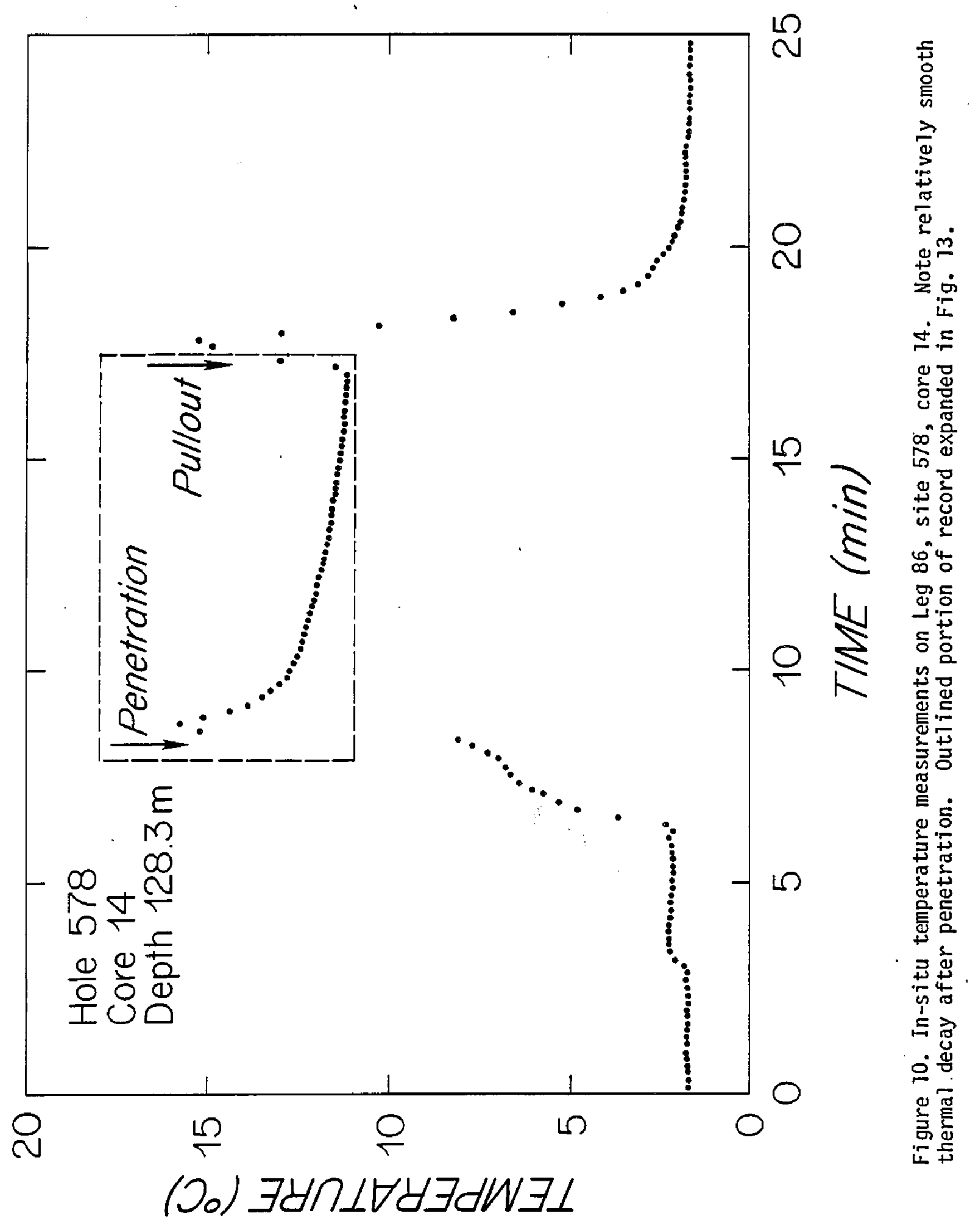




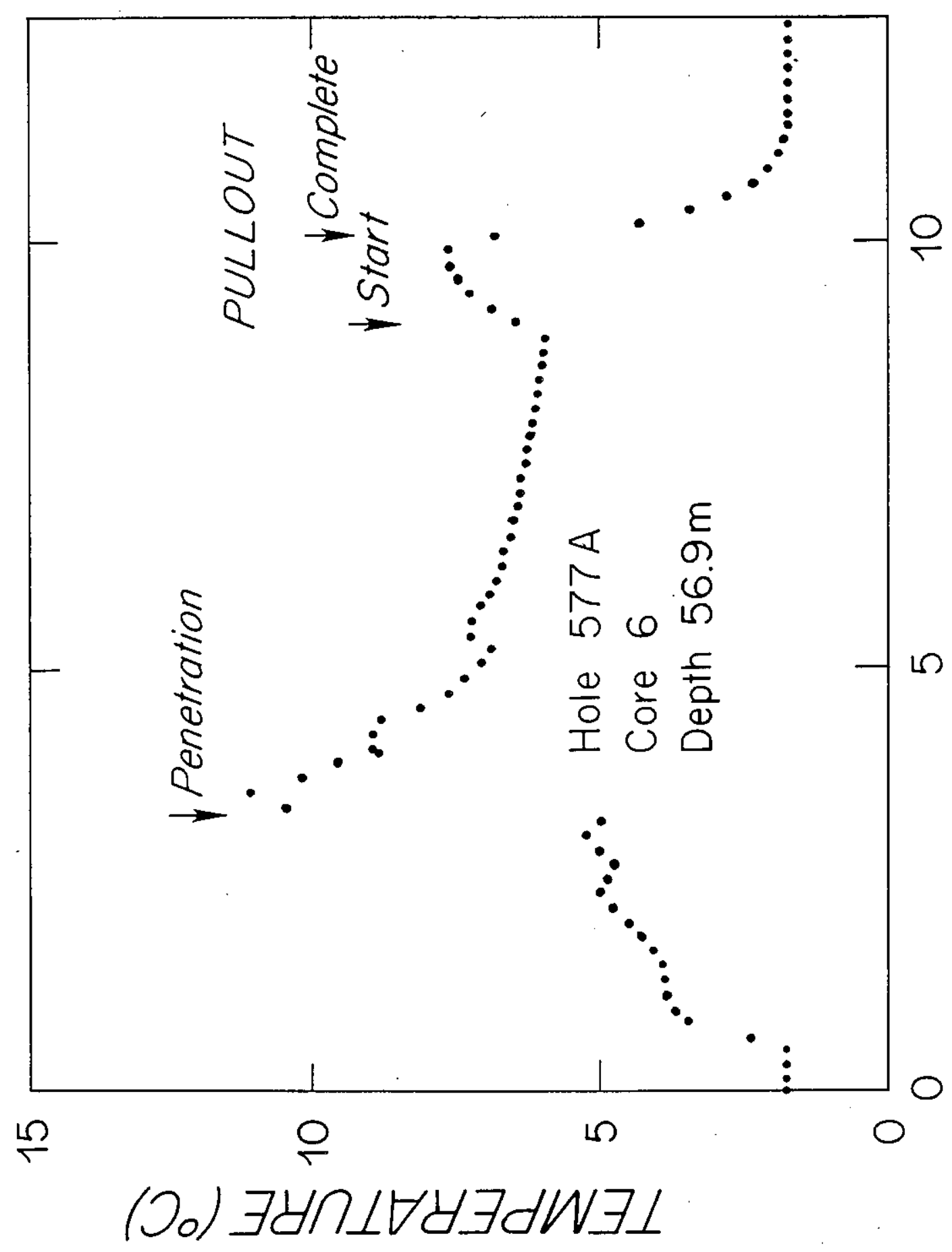

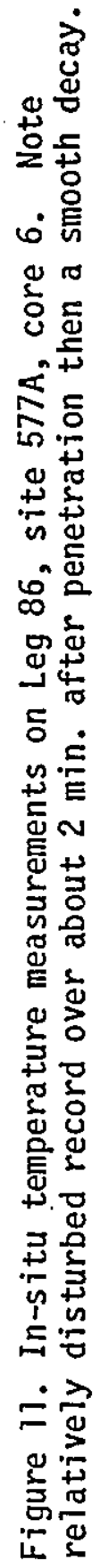




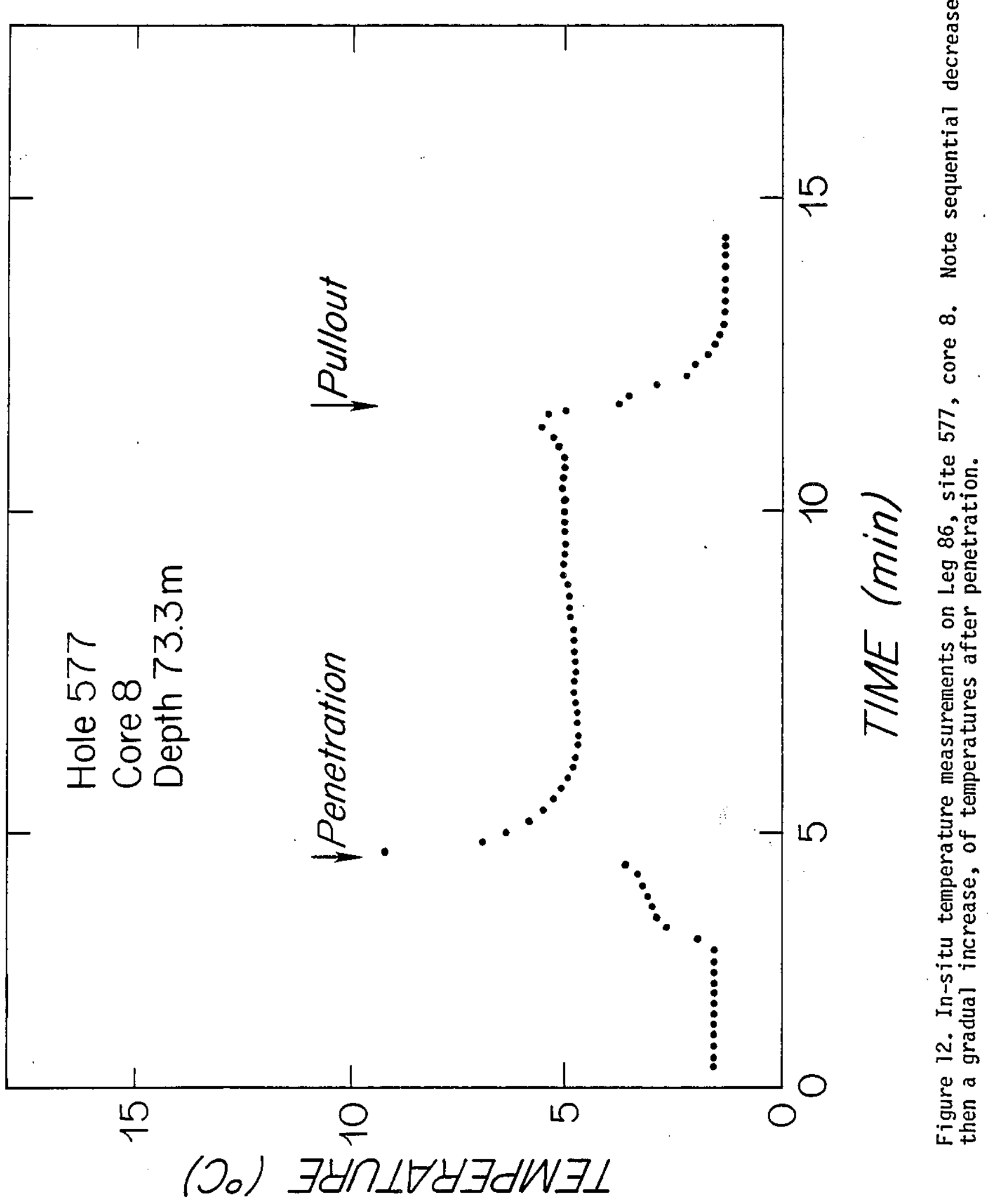


The HPC temperature instrumentation was also used on several legs subsequent to leg 86 , but not as extensively. Unfortunately, three sets of instrumentation were lost on subsequent legs $(87,89$ and 90), which significantly limited the amount of data obtained. According to DSDP engineers (Dave Huey, pers. comm., 1984) these losses were caused by failure of the HPC hardware, and had little to do with the operation of the instrumentation itself. Although measurements had been planned for Leg 96, none were attempted because of the unstable sediments and the fear that the leaving the HPC in the bottom without circulation, even for a few minutes, might stick the drill pipe (W. Bryant, pers. comm.). Water circulation is accomplished by pumping seawater through the drill pipe from the ship, allowing it to flow out the drill bit and up around the annulus between the drill pipe and the hole walls. This cannot be accomplished with the HPC extending out the bit. A useful development would allow seawater circulation through ports in the drill string above the drill bit after extension of the HPC. This might allow the HPC to remain extended at the same time that circulation above the HPC would prevent any cave-in or packing of sediments around the drill string.

Overall, it seems that the primary factor limiting use of the HPC is the lack of interest or motivation of shipboard scientists to obtain data. Otherwise there is little reason why such measurements could not be made an almost routine part of HPC operations.

\section{B. EXTRAPOLATION TO EQUILIBRIUM TEMPERATURES}

During the time the HPC is in the bottom, the frictional heat generated by the penetration is conducted away to the surrounding sediments (Fig. 10). The two-dimensional radial conduction theory for the physical configuration of the HPC has been solved numerically by $K$. Horai (pers. comm., 1984). Both the theory and experimental field data show that the excess temperature of the HPC over in-situ values is reduced to about $15-20 \%$ of its initial value after about 10 minutes in the sediment. It is not practical to leave the extended core barrel in the sediment much longer than this, so that an accurate extrapolation of the frictional heating pulse is necessary.

A comparison between the theory of Horai and an actual measurement is shown in Figure 13. The agreement between theory and practice is extremely close after the first few data points $(40-60 \mathrm{sec}$.$) . The lack of agreement$ during the first few data points occurs when the temperature distribution in the HPC wall is probably not uniform. A small remaining problem seems to be that the theoretical temperatures fall slightly below the temperatures measured near the end of the thermal decay. This may be due to the fact that the anomalous heat in the HPC is being conducted axially, as well as radial1y. The excess heat in the HPC is conducted preferentially toward the thin end of the wedge shaped cutting shoe, where the thermistor is located (Fig. 6). This would tend to cool the HPC more rapidly than if the HPC were infinitely extended along its axis, as assumed in the two-dimensional theory.

Therefore, in the measurements for Leg 86, Horai and Von Herzen (1985) assume that the true in-situ equilibrium temperature lies between the last measured point during the HPC penetration, and the theoretical 


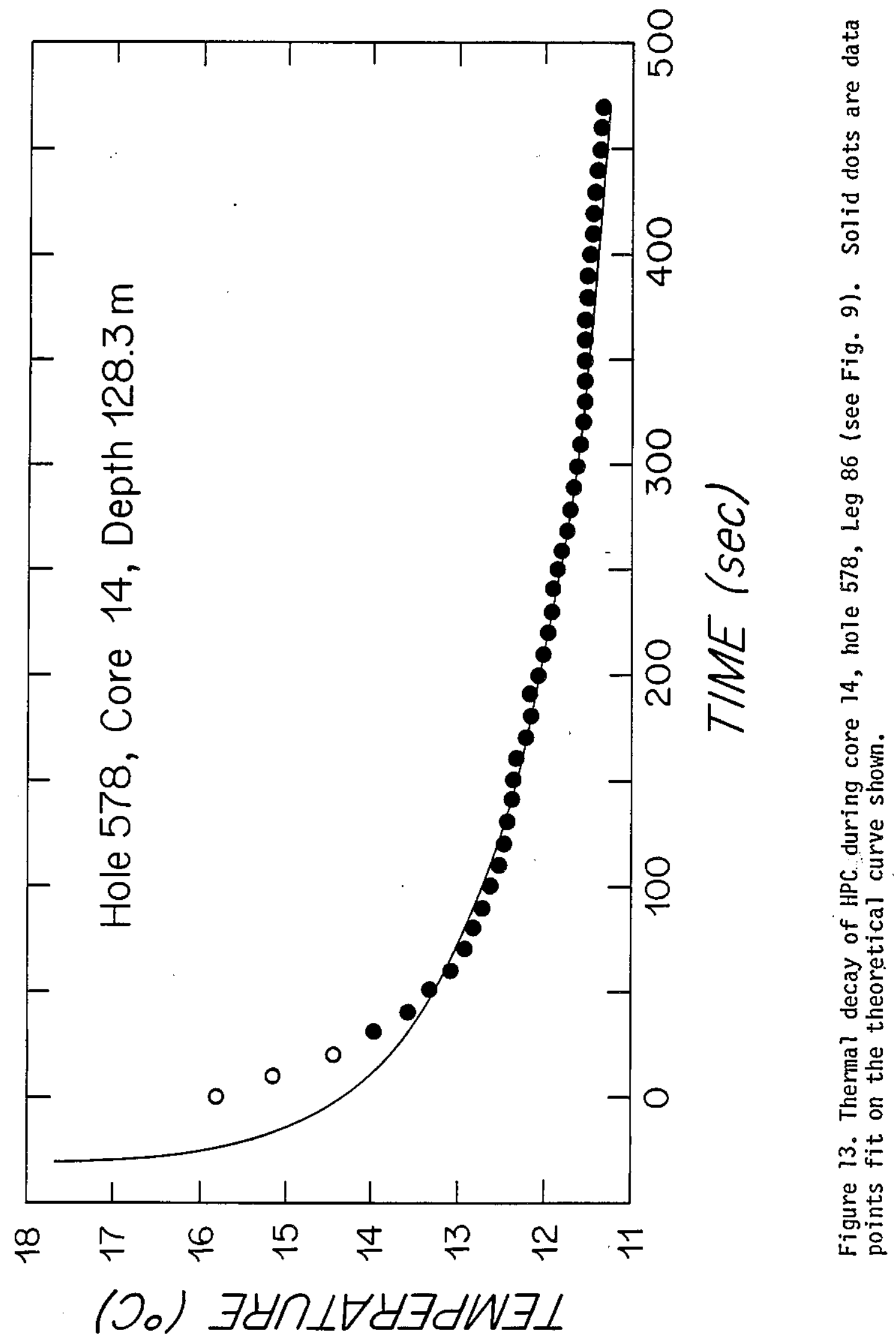


extrapolated value. Probably the true in-situ temperature is much closer to the value extrapolated using the two-dimensional theory, as seems to be the case from the comparison of the curves (Fig. 13). This should be tested by attempting to leave the HPC in the bottom as long as possible so that the data may be compared with the theoretical extrapolation.

Another useful set of data is the temperature of the near-bottom water measured by the HPC during its passage through the drill pipe. The temperature of the water in the drill pipe is usually close to that of the surrounding sea water, so that a calibration of the instrumentation can be obtained for each measurement. This is particularly useful if different sets of instrumentation are used for measurements in the same hole. It provides a useful check on the accuracy of the data obtained, and also provides another temperature data point at the sea floor.

\section{TEMPERATURE CALIBRATION STABILITY.}

We have some limited data on the temperature stability of some units, based on accurate repeated calibrations. Altogether 10 hybrid electronic units were constructed. One was not calibrated, because it was left as a hybrid that could be adapted to fit the annular cavity of the new cutting shoe, with the possible addition of acoustic communication. Three others were lost during operations at sea shortly after they were constructed and calibrated; hence, no history of stability over time exists for these units. Of the six other units, four (units Nos. 5, 6, 7, and 8) were calibrated in the laboratory two or more times, which provides evidence of temperature stability.

Calibrations were performed with the entire unit immersed in a stable water bath, at 7 temperatures uniformily distributed at about $10^{\circ} \mathrm{C}$ intervals over the range 0 to $60^{\circ} \mathrm{C}$, as described above. The differences between calibrations in 1983, over a period of about 11 months for units Nos. 5 and 6 , and about 7 months for units Nos. 7 and 8 , are shown in Fig. 14a. Similarly, the differences over about 11 months in 1984 for al1 4 units are illustrated in Fig. 14b.

The equivalent temperature shifts shown by the 1984 calibrations are within $.01-.02^{\circ} \mathrm{C}$ over the entire temperature range for all units, and for 2 of the units (Nos. 7, 8) in the 1983 calibrations. These are probably within the resolution of measurement for these units. The larger shifts $\left(.05-.07^{\circ} \mathrm{C}\right)$ for units Nos. 5 and 6 in 1983 may correspond with the ir use on Leg 92 and subsequent legs. The shifts are fairly uniform over the entire temperature range, suggesting that the thermistor sensor (most likely) or a bridge resistor may have changed as a result of physical shocks associated with the measurements. (Note that units Nos. 5 and 6 shifted in the opposite sense from each other.) Unfortunately, the units used extensively on Leg 86 were lost in operations on subsequent legs before they could be recalibrated. 


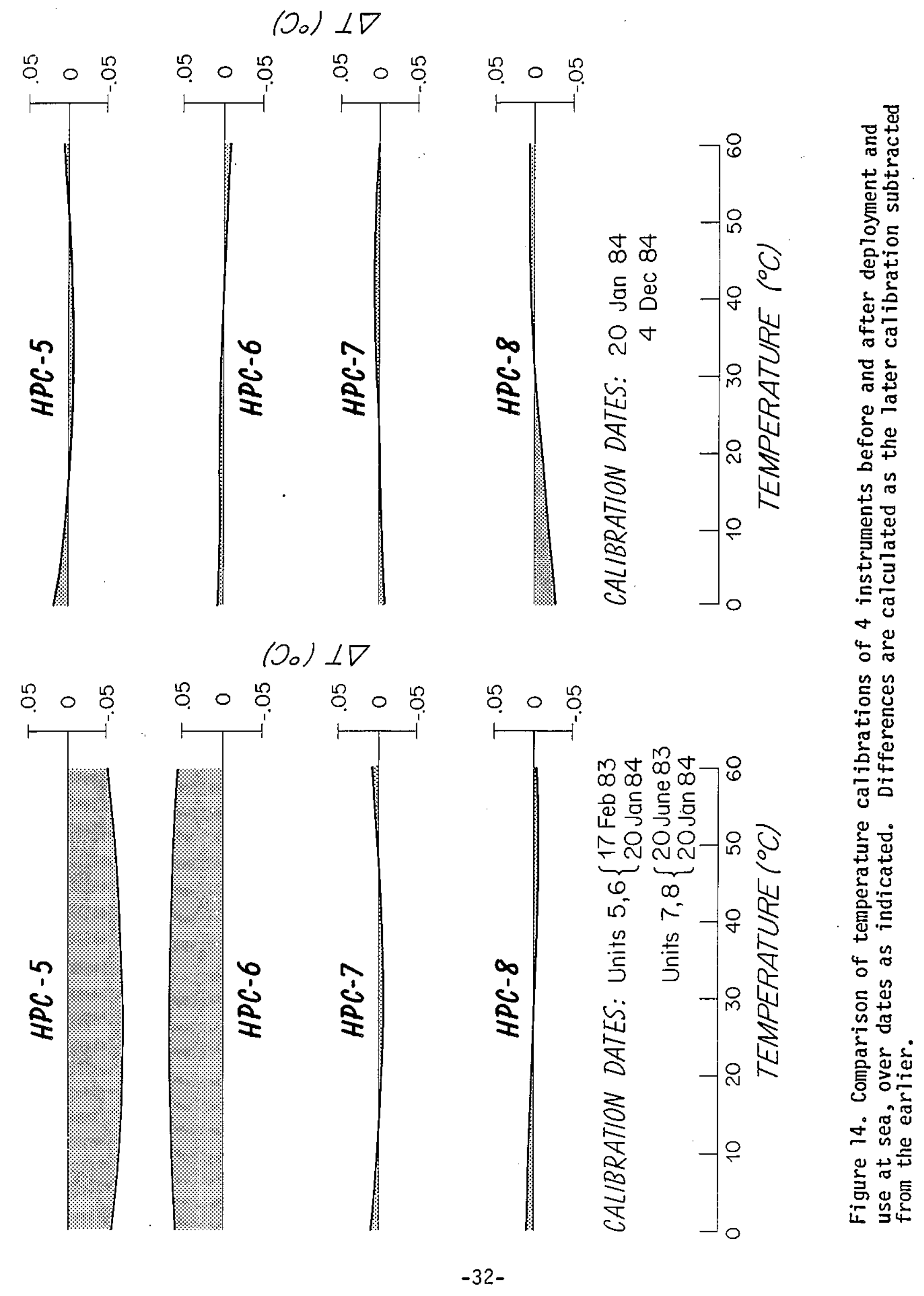


VII. FUTURE

The current software for the temperature recorder provides a sampling interval in the range of 0.1 to $6553.5 \mathrm{sec}$. The $0.1 \mathrm{sec}$ sampling interval corresponds to an upper frequency limit of $5 \mathrm{~Hz}$ (the Nyquist sampling rate) or $2 \mathrm{~Hz}$ (if you want to preserve the waveform). This rate would fill the memory in 130 seconds. The longest sampling interval of $6553.5 \mathrm{sec}$ corresponds to a minimum period of $1.82 \mathrm{hr}$ (at the Nyquist rate), or $4.55 \mathrm{hr}$ (for waveform preservation). This slowest rate would take $2366 \mathrm{hr}$ to fill the memory, which far exceeds the battery life (approximately 20 hrs.).

Other applications are possible for the temperature recorder. The input is an A/D converter, so it could be adapted to measure any voltage or resistance bridge measurement. A possible application is to measure the output of a strain gage type pressure transducer, or the voltage output of any sensor that has a voltage output. The A/D converter can sample up to 25 times per second, if the integrating capacitor is changed and the software modified. This implies an upper frequency 1 imit of $12 \mathrm{~Hz}$ (the Nyquist rate) or $5 \mathrm{~Hz}$ (waveform preservation). The lowest frequency is limited by the memory size and the sampling rate. At 25 samples per second, the memory would be filled in 52 seconds. At the other extreme, data rates may be as long as desired to fill the memory (currently 1300 2-byte words), limited only by battery life.

The present coring shoe cavity has been enlarged in a new design, which has the same diameter as the original cavity, but it extends completely around the coring tool to form an annulus. It is $0.28 \mathrm{in}$. thick and $5 \mathrm{in}$. long. This larger cavity, if layed out flat, would be 10 in. long, by 5 in. wide, by $0.28 \mathrm{in}$. thick. It was possible because the strength of a shell (the cylinder) is much stronger than a flat plate. Actually, the small cavity is probably stronger that we calculated (see Appendix A), but we conservatively used the formula for a flat plate. This new cavity was made by welding the outer wall to the piece containing the cutting edge and the inner wall. It was no more expensive than the previous design, because no EDM (electro discharge machining) was necessary. It was designed at the DSDP at Scripps. There is some question about the strength of the cylinder wall under impact, but that can be tested. If it would fail under severe impact, you could take your chances, and accept a loss if it does fail. However you would not want it to be damaged, then deform under pressure and get stuck in the drill string.

The whole diameter of the coring tool can be used for instrumentation where only drilling and logging is being done and the material being drilled is too hard for HPC coring. This increases the space available for additional instrumentation.

Each time data is read from the temperature recorder, the coring shoe has to be opened up to enable connection to the instrument, and cleaned and closed up for the next use. This is troublesome, as well as risky by exposing the electronics to possible damage from salt water, or the chance of losing data by inadvertently disconnecting the battery. 
The temperature recorder could use acoustic communication through the wall of the cavity in the coring shoe. A small transducer about the size of a dime could transmit using a $1 \mathrm{MHz}$ carrier, using frequency shift keying. It could also receive instructions. With the large annular cavity, there would be plenty of room for batteries, certainly enough to last one leg (2 months), or possibly even for a year. So the instrument would not have to be opened up during use, or possibly not at sea. It could be sent back to the lab for new batteries.

At one time flexible printed circuits were considered as an alternative to the hybrid. A flexible circuit was tried in a rolled up circuit for another instrument, and it was discovered that the traces break where they are soldered to the integrated circuit packages. The flexible board industry laminates rigid boards to the flexible circuit in the regions where there are electronic parts, and uses the flexible part only to interconnect the rigid boards. If such a structure were used in the hollow annulus, it would take up most of the space. The resistance to physical shock is problematical. However, the hybrid is difficult and somewhat expensive to produce in small quantities, which might be alleviated with a more spacious layout using small outline package IC's on boards with flexible interconnections. Another possibility is combining multiple hybrids on separate hard boards, with flexible interconnections.

There has been a desire expressed to reach higher temperatures, perhaps $200^{\circ} \mathrm{C}$. The present design has a nominal 1 imitation of $75^{\circ} \mathrm{C}$, determined by the temperature rating of the A/D converter. All other parts are rated to $125^{\circ} \mathrm{C}$. The batteries can last a short time at $70^{\circ} \mathrm{C}$. Eutectic solder $(63 \%$ tin, $37 \%$ lead) melts at $183^{\circ} \mathrm{C}$, and other ratios get mushy at this temperature.

To reach $200^{\circ} \mathrm{C}$, the entire electronics circuitry and power supply would have to be redesigned with higher temperature parts. Such high temperatures would normally be encountered at depths or in regions (e.g., ridge crests) where the materials are too hard to use the HPC. If the entire diameter of the coring tool could be used for instrumentation, then existing higher temperature batteries ( 0.55 in. diameter) could be considered. Hybrid circuits at $200^{\circ} \mathrm{C}$ could probably be fitted into the 0.28 in thick space inside the wall of a coring tool. The thermometer would be a platinim resistance thermometer of some type of rugged construction. Absolute accuracy of $0.5^{\circ} \mathrm{C}$ seems possible at the higher temperatures. 


\section{ACKNOWLEDGEMENTS}

Several persons have contributed significantly to this project. Ed Mellinger wrote the assembly language programs for the recorder and participated in the design of the electronics and construction of the breadboard. Skip Pelletier wrote the programs for the personal computers (Apple and Pro-350) for controlling the temperature recorder, and processing the recorder data. Dave Huey and Mike Storms (DSDP) designed and arranged for construction of the special coring shoe, Don Bellows (DSDP) did the same for the new annular cavity coring shoe. Charlie Yiakas and Dave Vacca (TSI) were always helpful and patient in consultation and for construction of the hybrid circuit. Ki-iti Horai gave the recorder its first extensive field tests on Leg 86 of the DSDP, and developed the theory to obtain equilibrium temperatures from transient thermal decay of the corer.

We are grateful for the financial support provided for various phases of this project:

1. USGS (Woods Hole) for the initial support to begin development of instrumentation (Project No. 17-18920.22); to the Ocean Industry Program, WHOI (Project No. 4471) to complete the development.

2. NSF, Grants OCE82-14658 and OCE83-00073 to enable construction of additional units for field measurements and for data analysis. 


\section{REFERENCES}

Anonymous, Design and operation of an advanced hydrautic piston core, Tech. Rept. 21, Deep Sea Drilling Project, University of California, 269 pp., July 1984 .

Anderson, R.N., M.A. Hobart, and M.G. Langseth, Geothermal convection through oceanic crust and sediments in the Indian Ocean, Science, 204, 828, 1979.

Anderson, R.N., M.G. Langseth, and J.G. Sclater, Mechanisms of heat transfer through the floor of the Indian Ocean, J. Geoph. Res., 82, 3391-3409, 1977.

Becker, K., and R.P. Von Herzen, Heat transfer through the sediments of the mounds hydrothermal area, Galapagos spreading center at $86^{\circ} \mathrm{W}, \mathrm{J}$. Geoph. Res., 88, 995-1008, 1983.

Erickson, A.J., and R.P. Von Herzen, Downhole temperature measurements and heat flow data in the Black Sea - DSDP Leg 42B, in: Initial Reports Deep Sea Drilling Project, vol. 42, part 2, by D.A. Ross, Y.P. Neprochnov, et a1. (U.S. Govt. Printing Office), 1085-1103, 1978.

Erickson, A.J., R.P. Von Herzen, J.G. Sclater, R.W. Girdler, B.V. Marshall and R. Hyndman, Geothermal measurements in deep-sea drill holes, $J$. Geoph., Res., 80, 2515, 1975.

Horai, K. and R.P. Von Herzen, Measurement of heat flow on Leg 86 of DSDP, in Initial Reports of DSDP, vol. 86, Washington (U.S. Government Printing Office), 759-777, 1985.

Roark, R.J. and W.C. Young, Formulas for Stress and Strain, Fifth edition, McGraw-Hi11, New York, 1975.

Steinhart, J.S., and S.R. Hart, Calibration curves for thermistors, Deep Sea Research, 15, 497-503, 1968.

Von Herzen, R.P., Geothermal measurements, Leg 21, in: Initial Reports Deep Sea Drilling Project vol. 21, by R.E. Burns, J.E. Andrews, et al. (U.S. Govt. Printing Office), 443-457, 1973.

Von Herzen, R.P., J. Crowe, and K.E. Green, The eastern equatorial Pacific ocean heat flow low: evidence of hydrothermal circulation, ms. in preparation.

Yokota, T., H. Kinoshita, and S. Uyeda, New DSDP downhole temperature probe utilizing IC RAM elements, Bull. Earthquake Res. Inst., 55, 75, 1980. 


\section{APPENDIX A. CAVITY STRENGTH CALCULATIONS}

\section{Kidney shaped cavity (currently used).}

The cavity had to fit into the $9 / 16$ in. thick wall of the coring shoe, and operate at 21,000 ft. deep (10 kpsi) with some margin of safety. A very strong heat treatable stainless stee1, Nimark 250, from Carpenter Technology, Carpenter Steel Division, Reading, PA, with a typical yield strength of $250 \mathrm{kpsi}$, was used for the portion of the coring shoe containing the cavity.

We selected a hybrid package to fit in the cavity. We made the width just large enough to accomodate the hybrid package $(0.80 \mathrm{in}$.$) and then$ made the cavity as high as possible. The actual cavity walls are curved (Fig. 6), so although the height of the cavity is $0.28 \mathrm{in.}$, the height of a rectangular hybrid package inscribed in the curved cavity is less. The length of the cavity is 5 in. to accomodate the combined package of hybrid and printed circuit board. A cylindrical hole 0.125 in. in diameter extends beyond the end of the cavity to accomodate the thermistor probe.

A flat plate approximation was used for the curved walls of the cavity. This approximation is conservative, in that the curved shape should be stronger. The width of the cavity used for the flat plate approximation is the portion of the arc of the outer wall that has uniform wall thickness, measured along the outside surface of the coring tool. The equation below is derived from formulas for flat plates with straight boundaries and constant thickness (Roark and Young, 1975, p. 386, Table 26).

The rectangular plate, shown in Figure $A-1$, has three edges fixed and one edge simply supported. The force is uniform over the entire plate. Using Table 26, Case 9 (Roark and Young, 1975, p. 394), the general form for the stress is:

$$
s=\frac{B q b^{2}}{t^{2}}
$$

where $a, b=$ the dimensions of the plate; $t=$ thickness of the plate; $q=$ unit force on the plate; and $B$ is a variable which depends on the ratio $a / b$ and the direction and location of the stress. B is taken from a table in the above reference which had to be extended to $a / b=0.16$ (vs, $a$ minimum of 0125 in the table) by graphical extrapolation on log-log graph paper.

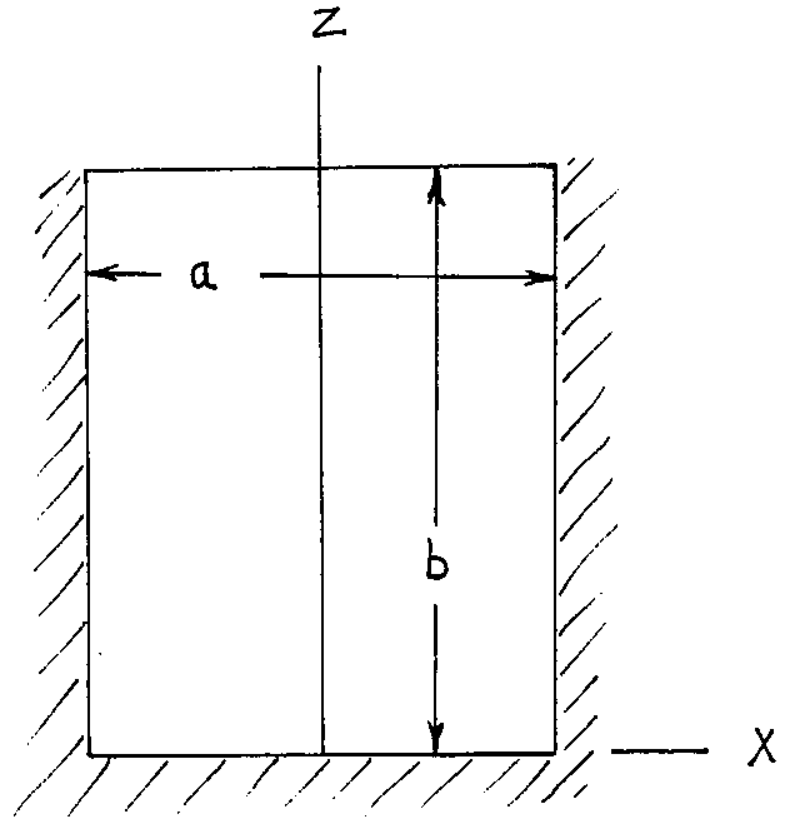

Figure A-1. Flat plate model used for cavity strength calculations. 
For $q=10,000$ psi, $a=0.800, b=5.00, t=0.145$, the maximum stress in the a direction (circumferentialiy) occurs at $x= \pm a / 2, z=$ $0.6 \mathrm{~b}$, for which $B=0.0133$,

$$
S_{a}=\frac{(0.0133)\left(10^{4}\right)(5)^{2}}{(0.145)^{2}}=158,200 \mathrm{psi}
$$

The maximum stress in the $b$ direction (axially) occurs at $x=0, z=0$, for which $B=0.0083$,

$$
s_{b}=\frac{(0.0083)\left(10^{4}\right)(5)^{2}}{(0.145)^{2}}=98,690 \mathrm{psi}
$$

The largest stress is $158 \mathrm{kpsi}$ in the outer wall, which is about $70 \%$ of the minimum yield strength ( $230 \mathrm{kpsi}$ ) of the material. The curvature of the plate serves to strengthen the plate further, but is not included in the calculation. The coring shoe was tested at and survived $10 \mathrm{kpsi}$, the working pressure. It was not tested at a higher pressure for fear of collapsing the cavity. However, we infer from the calculations for the. strength of an annular cavity (see following) that the actual strength of this cavity design may be considerably stronger.

The cavity for the battery was made the same size as the electronics, except for length. It is 3 in. long, while the cavity for the electronics is 5 in. long.

An annular cavity, the same thickness as the electronics cavity and 0.25 in. deep, provides space for compression of the air when the two parts of the coring shoe are screwed together. Without this space, the air compressed in the cavity would bend the top of the lid of the hybrid package and short out the hybrid circuitry.

\section{Annular Cavity.}

A much larger space for the electronics can be achieved if an annulus were hollowed out of the interior of the coring shoe. A cylinder is stronger than a flat plate. A short cylinder is stronger than a long cylinder because the support from the ends has more influence on a short cylinder. The cylinder can fail either in collapse or in buckling. Different equations are used for each case, and the lowest pressure at which the cylinder fails is the one that is used. A number of lobes are formed by the tube in buckling. The buckling pressure for each lobe number is calculated and the lowest buckling pressure is the one used.

The dimensions of the original coring shoe (Fig. 6) were used, which would make the same thickness available for the electronics. First the collapse equations are used, which result in a collapse pressure of 25,350 psi for the inner cylinder and 17,925 psi for the outer cylinder. Then the pressure for buckling the cylinder for a given number of lobes is calculated versus the cylinder length. Plots were made of pressure vs. length for each 
number of lobes. Then, using the minimum buckling pressure of all the curves, length or pressure can be chosen. We chose $5 \mathrm{in.}$ long, which gave a buckling pressure of 18,000 psi, with 3 lobes.

\section{Cylinder collapse strength.}

The walls of the annulus are concentric cylinders, each considered as a short supported tube (Fig. A-2). The cylinders are fixed at one end and simply supported at the other.

The material used is Nimark 250 , with the following characteristics:

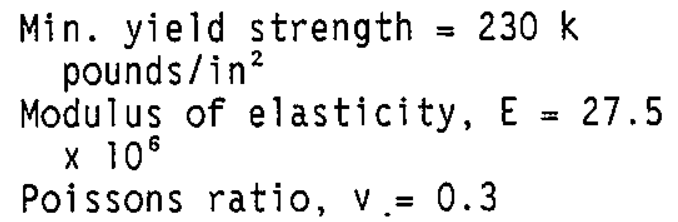

The equations below are from Table 32 (Roark and Young, p. 504): Formulas for a thick walled vessel under internal and external loading. Notation: $a=$ outer radius; $b=$ the inner radius; $s_{2}=$ normal stress in the circumferential direction; $v=$ Poissons ratio.

The inner cylinder has uniform internal pressure, $q 1 \mathrm{~b} / \mathrm{in}^{2}$, in all directions; ends capped. Using Table

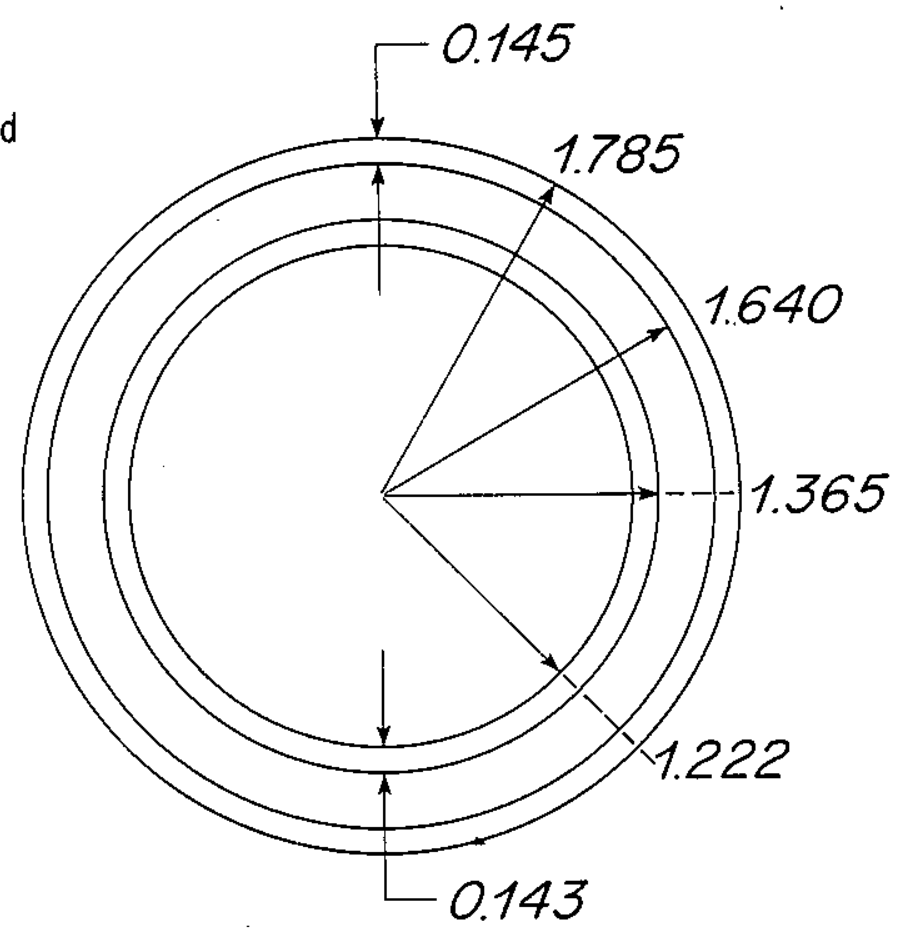
32. Case lb (Roark and Young, p 504),

Figure A-2. Cross section view of the hollow annulus.

$\max s_{2}=a \frac{a^{2}+b^{2}}{a^{2}-b^{2}}$ at $r=b$

For

$$
\begin{aligned}
& a=1.365 \\
& b=1.222
\end{aligned}
$$

$\max s_{2}=\left(10^{4}\right) \frac{(1.365)^{2}+(1.222)^{2}}{(1.365)^{2}-(1.222)^{2}}=25,350 \mathrm{psi}$

The outer cylinder has uniform external pressure, $q 1 \mathrm{~b} / \mathrm{in}^{2}$, in all directions; ends capped. Using Table 32, Case 1d (Roark and Young, p. 504),

$$
\max s_{2}=\frac{2 q a^{2}}{a^{2}+b^{2}} \text { at } r=b
$$


For $a=1.785$
$b=1.640$

$\max s_{2}=\frac{2\left(10^{4}\right)(1.785)^{2}}{(1.785)^{2}-(1.640)^{2}}=17,925$ psi

\section{Elastic instability calculations.}

The outer cylinder is subject to elastic instability because it has external pressure. A cylinder with supported ends has a higher pressure for elastic instability, as it becomes shorter.

The equation below is from Table 35, Formulas for elastic stability of plates and shells (Roark and Young, p. 556). Notation: $E=$ modulus of elasticity; $v=$ Poisson's ratio; and $t$ = thickness for plates and shells.

The thin tube has closed ends under uniform external pressure, lateral and longitudinal (length of tube $=\ell$; radius of tube $=r$ ). The ends are held circular. Using Table 35, Case 20 (Roark and Young, p. 556), where $q^{\prime}=$ external pressure at which elastic buckling occurs:

$q^{\prime}=\frac{E\left(\frac{t}{r}\right)}{1+\frac{1}{2}\left(\frac{\pi r}{n \ell}\right)^{2}}\left\{\frac{1}{n^{2}\left[1+\left(\frac{n \ell}{\pi r}\right)^{2}\right]^{2}}+\frac{n^{2} t^{2}}{12 r^{2}\left(1-v^{2}\right)}\left[1+\left(\frac{\pi r}{n \ell}\right)^{2}\right]^{2}\right\}$

here $n=$ number of lobes formed by the tube in buckling. As described by Roark and Young, to determine $q^{\prime}$ for tubes of a given $t / r$, a group of curves is plotted for each integral value of $n$ of 2 or more, with $\ell / r$ as ordinate and $q^{\prime}$ as abscissa; that curve of the group which gives the least value of $q^{\prime}$ is then used to find the $q^{\prime}$ corresponding to a given $\ell / r$.

Plots of this equation are shown in Fig. A-3, where pressure is plotted vs. length of the cylinder, for $r=1.785 \mathrm{in}$. and $t=0.145 \mathrm{in}$.

The buckling pressure is $18 \mathrm{kpsi}$, for a length of $5 \mathrm{in.}$, which is nearly the same as the collapse pressure for this shape. Thus, the walls of the 5 in. long cylindrical annulus are more than strong enough to withstand $12 \mathrm{kpsi}$ at the bottom of the drill string. 


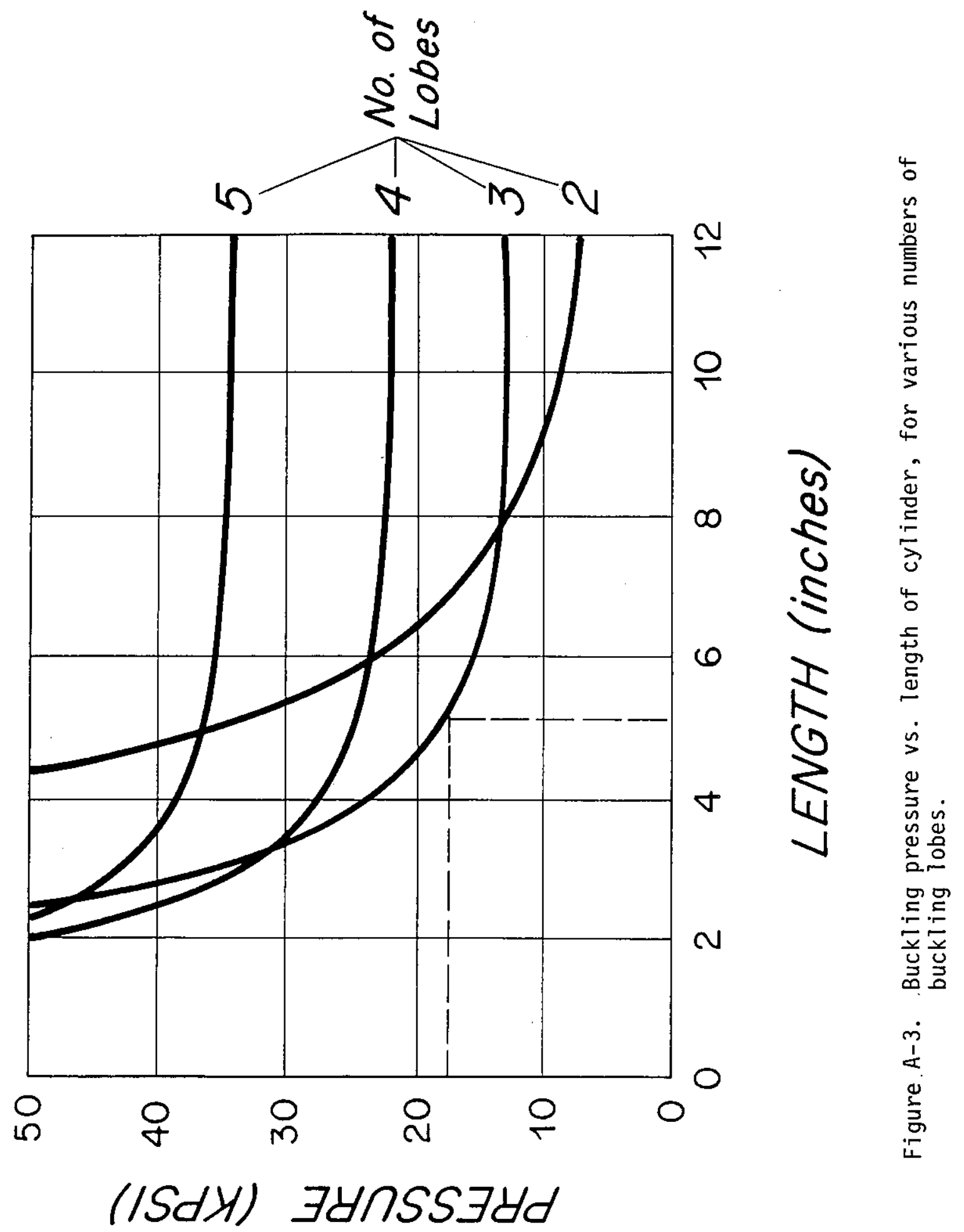




\section{APPENDIX B. DETAILED DESCRIPTION OF ELECTRONICS}

\section{Description of Block Diagram.}

The block diagram (Fig. 4) corresponds very closely in structure to the actual schematic. The temperature recorder consists of 7 blocks plus battery: the microprocessor, RAM, UART, A/O converter, thermistor bridge, power supply, and battery. The measurement begins with the thermistor bridge, with a voltage nearly linear with temperature. The A/D converter digitizes this voltage with 13 bit resolution. The microprocessor instructs the $A / D$ converter when to convert and stores the measurement in memory. The UART is used to send the stored data serially to an awaiting external device (a computer). The UART is also used to load the program into RAM for 2-way communication with the computer.

A voltage regulator provides 5 volts to the electronics from an 8 volts battery. A 4 volts mode is available to reduce power consumption. The power switch controls the 5 volts to the A/D converter, so that it may be shut down when not being used, in order to save power. The voltage inverter converts some of the 5 volts to -5 volts for the A/D converter.

\section{Detailed Description of the Schematic (Fig. B-1).}

The 1802 microprocessor controls all the rest of the elements of the temperature recorder. A crystal of $38.4 \mathrm{kHz}$ runs with the internal oscillator of the microprocessor to provide the computer clock. A low frequency was chosen to save power, since the microprocessor does not have to work very fast. The clock frequency was chosen so that a binary divider chain can provide the UART clock input, which is $16 \mathrm{x}$ the UART baud rate.

There are 3 kbytes of RAM, controlled thru the 1866 memory selector, by the address lines of the microprocessor. The 8 address lines are multiplexed. The high order byte comes out first and the low 4 bits are stored in the 1866. Two bits drive the RAMs directly and two are decoded to select the RAMs. The low order byte comes out second and drives the address lines of the RAMs directly. The RAMs are $1 \mathrm{k} \times 4$ bits, so 2 RAMs are used simultaneously: one for the upper four bits of data, and one for the lower 4 bits of data. $A$ write enable line from the computer is active when writing to memory. The address lines and the inhibit for the 1866 selector come outside the hybrid so it can be tested, more memory added or other memory substituted for the internal memory.

The UART runs at 1200 baud, and provides 2-way communication thru the 9 pin recorder connector. The clock for the UART is $19.2 \mathrm{kHz}$, which is $16 \mathrm{x}$ the 1200 baud rate, derived from a binary divider on the computer clock. The baud rate can be changed on the printed circuit board.

The UART 8 bit data busses for transmitting and receiving are connected to the microprocessor data bus. The transmit buffer is loaded by I/O line 5 , and the receiver buffer is read by $1 / 01$ ine 4 . These 1 ines come from the $1853 \mathrm{~N}$ line decoder. When data has been transmitted, the transmit buffer 


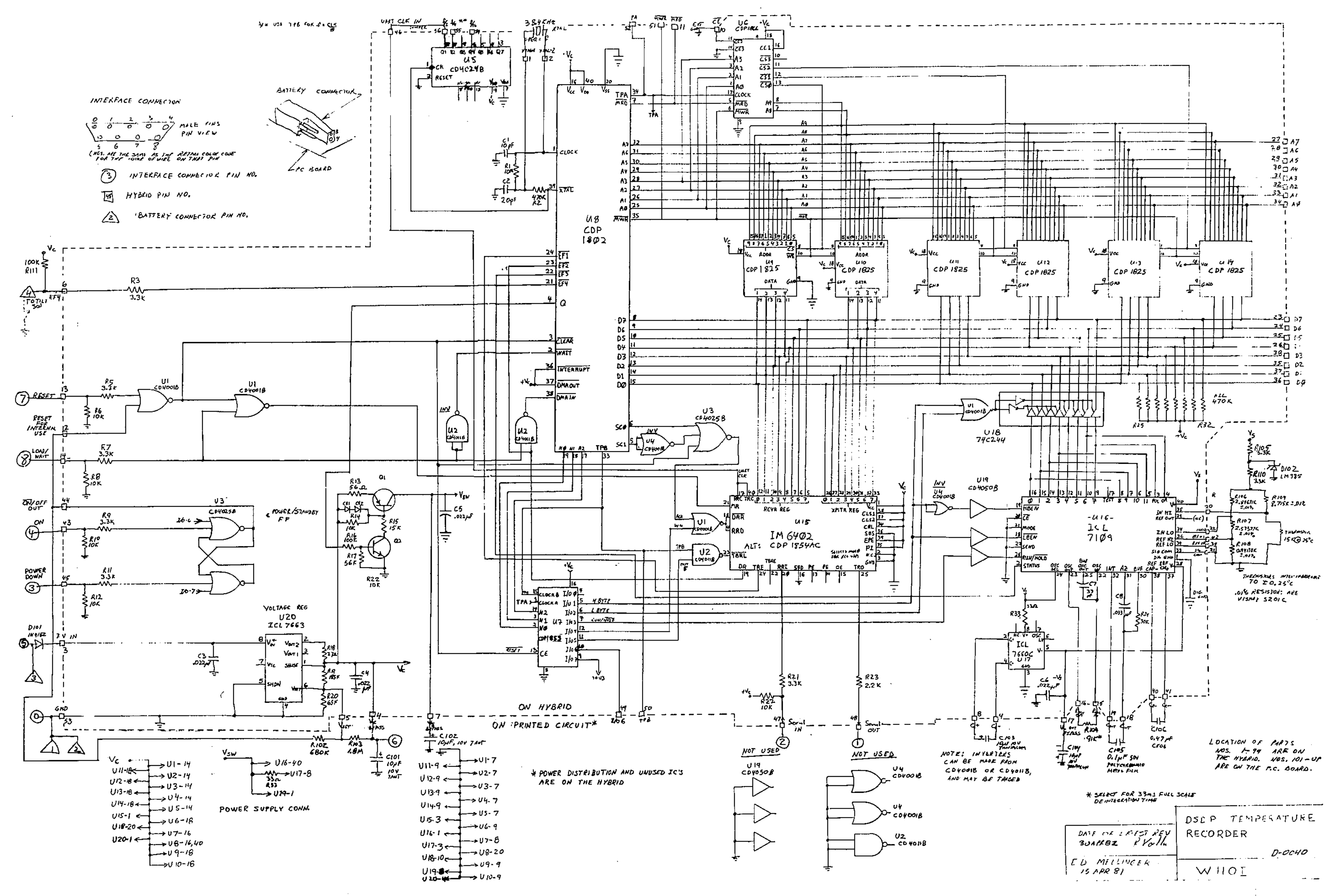

Figure B-1. Schematic of the temperature recorder. 
empty line raises (to inverted logic 0 ) the external flag 1 input (EFI-bar) of the microprocessor. When the receive buffer is full, the data ready line raises the external flag 2 input (EF2-bar) to the microprocessor. The microprocessor has to test these flags to determine the state of the UART.

A dual slope type $A / D$ converter is used to measure the bridge output. Its integration period is set to $1 / 60$ second to average out $60 \mathrm{~Hz}$ pick-up while making lab measurements. The A/D converter averages out noise over the integration period, which means it is less sensitive to noise.

The run/hold line for the A/D is controlled by I/O line 3 . This line, as well as the high byte enable and low byte enable for data output are driven by buffers that get their power from the A/D power, but do not load the driving source when the A/D power is switched off.

The reading of the high byte out of the $A / D$ is enabled by $I / O$ line 1 , and the low byte by $1 / 0$ line 2. A tri-state buffer is used between the A/D data output and the data bus so the A/D converter can be turned off without pulling the data bus down.

The bridge circuit for the thermistor is made of Vishay (Malvern, PA) resistors, which are very stable and temperature insensitive $\left(\left\langle 1 \mathrm{ppm} /{ }^{\circ} \mathrm{C}\right)\right.$. The bridge runs at a low voltage so that only about $10 \mathrm{~m}^{\circ} \mathrm{C}$ self heating of the thermistor occurs. The self heating, which varies about $30 \%$ over the temperature range, is included in the temperature calibration. A zener-like voltage regulator provides 2.5 volts to the bridge to keep the small fluctuations ( 25 $\mathrm{mV}$ ) in the 5 volts line from changing the voltage to the bridge during conversion.

The inactive leg of the bridge also provides the reference voltage for the $A / D$ converter, which is set to about $200 \mathrm{mV}$. A ratiometric measurement is made from the bridge voltage, so the exact voltages are not important. A convenient feature of this $A / D$ converter is the Input Lo terminal, a floating high impedance input, which allows us to center its operating range in the middle of the bridge output swing. Thus we can use both the positive and negative range of the 12 bit plus sign $A / D$ converter to obtain a 13 bit conversion.

An I/O instruction has numbers 1 thru 7 , which is encoded into 3 bits on the NO, N1, and $\mathrm{N} 2$ lines. The $1853 \mathrm{~N}$ line decoder decodes these 3 bits into 8 lines for operating various I/O devices. These are:

1. IN 1 - high byte enable on $A / D$.

2. IN 2 - low byte enable on $A / D$.

3. OUT 3 - Run/Hold on A/D.

4. IN 4 - read UART receive buffer.

5. OUT 5 - load UART transmit buffer.

6 . OUT 6 - raise power supply voltage to 5 volts (also available as an output pin for control of an external device).

7. OUT 7 - lower power supply voltage to 4 volts. 
Although these lines can be programmed to be inputs or outputs, they are wired to do only one or the other (except for the potential use of I/O line 6).

A very low power voltage regulator supplies a regulated 5 volts to the electronics, when the computer is running normally. It can be switched by I/O line 7 to regulate at 4 volts for standby to hold the data at about $1 / 2$ the current (about 0.5 mamp) as at 5 volts. Under program control the voltage is switched to 4 volts after the data has been acquired. The computer seems to run at 4 volts, but proper operation of the computer and memory is not guaranteed below 4.5 volts. The power can be raised to 5 volts with I/0 line 6 .

To further save power after the data has been acquired, an Idle instruction stops the microprocessor, while the clock continues to run. This chops the current by another factor of 2 to about 0.25 mamp when the supply voltage is 4 volts. As it is wired up (no interrupts), the microprocessor cannot get out of the idle condition by itself, but must be reset externally.

A power switch, controlled by the $Q$ line of the microprocessor, switches the +5 volts for the A/D converter. A 7660 voltage inverter, powered by this switched +5 volts, generates the -5 volts for the A/D converter. The A/D converter consumes about 2.5 mamp when on, so considerable power is saved when it is turned off.

The 1802 has a convenient Load mode, using the DMA IN input. Data from the UART is read into the memory, starting at address $0000_{H}$, when in load mode and the DMA IN line is low. The Data Ready line of the UART controls the DMA IN line (via a gate) when in the Load mode. The load mode is entered by raising the reset and the load line in that order. 
APPENDIX C. DETAILED LIST OF INPUT/OUTPUT INSTRUCTIONS

Details on the Temperature Recorder Computer Instructions.

Below are instructions specific to this particular computer. See the RCA 1802 programming manual for the general programming of the 1802.

The memory is 3 kbytes $(3 \times 1024)$, which is addressed sequentially from $0000_{H}$ through $0 \mathrm{BFF}_{\mathrm{H}}\left(3071_{0}\right)$. The same memory is addressed each 4 kbytes up to 64 kbytes, because the address decoder does not look at the upper 4 bits.

\section{Input/Output Instructions}

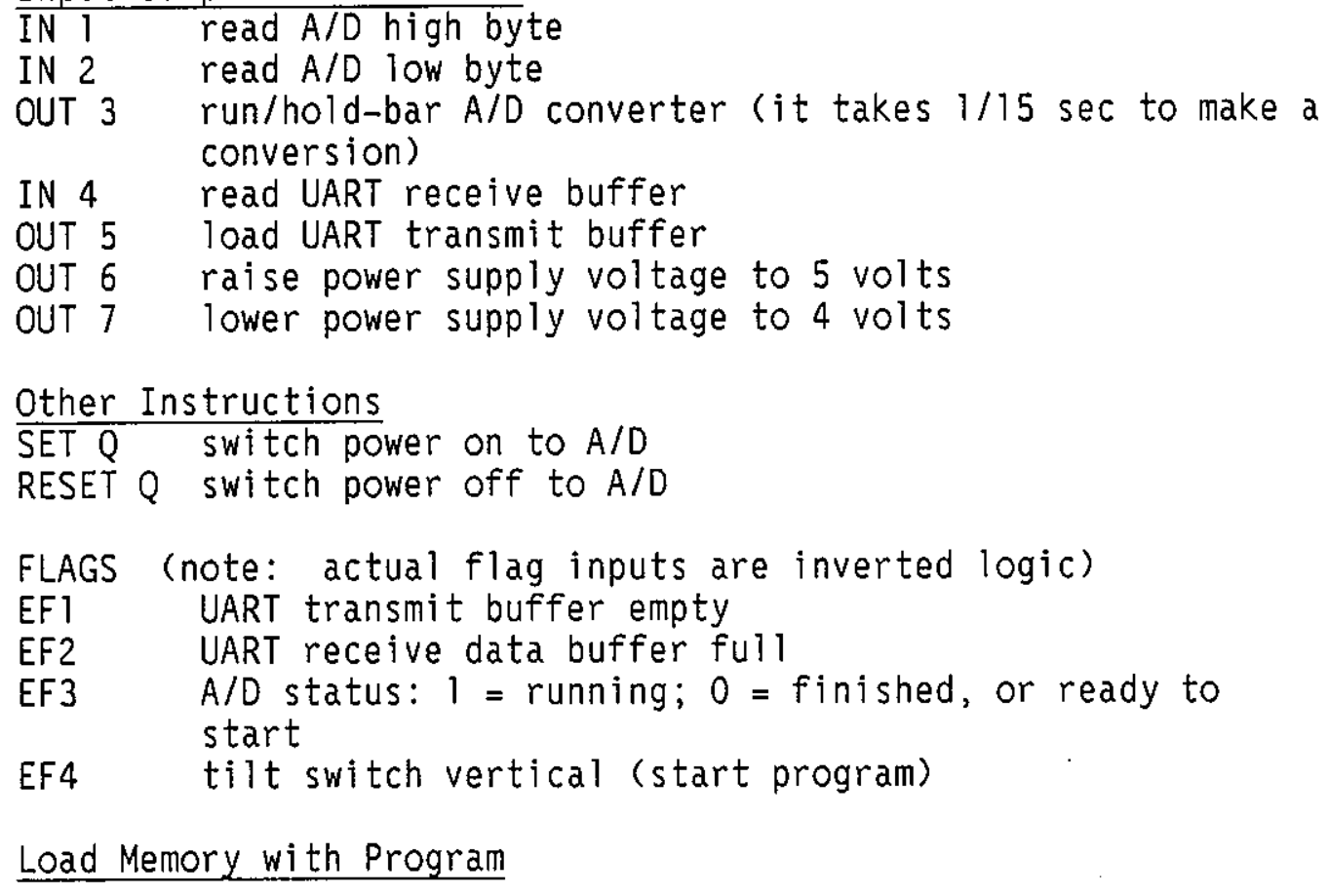

To terminate load, lower the load line to 0 volts, then lower the reset line to 0 volts.

Now the program will start at location 0000.

$\underline{\text { UART }}$

The UART runs at 1200 baud, 8 bits, no parity. $1=5$ volts, $0=0$ volts. 


\section{APPENDIX D. BRIDGE CIRCUIT EQUATIONS}

The bridge circuit for the thermistor is shown in Fig. D-1.

$E_{1}$ is the input voltage to the bridge.

$E_{I N}$ is the voltage into the $A / D$ converter. The negative input to the $A / D$ converter is derived from the inactive leg of the bridge, and is at the center of the bridge excursion.

$E_{R \varepsilon F}$ is the reference voltage into the $A / D$ converter. The reference voltage is $1 / 2$ the full scale input to the $A / D$ converter. This reference voltage is derived from the inactive leg of the bridge, instead of from a separate divider.

The A/D converter is ratiometric, that is, measures $E_{I N} / E_{R E F}$.

Therefore, the value of $E_{1}$ is not important, as long as it is stable shortly before and during a measurement.

The circuit can easily be solved for $R_{2}$, the thermistor resistance, as follows:

$$
R_{2}=\frac{R_{1}\left(\frac{R_{4}}{R_{5}}+1+\frac{E_{t n}}{E_{r e f}}\right)}{\left(\frac{R_{3}}{R_{5}}-\frac{E_{i n}}{E_{r e f}}\right)}
$$

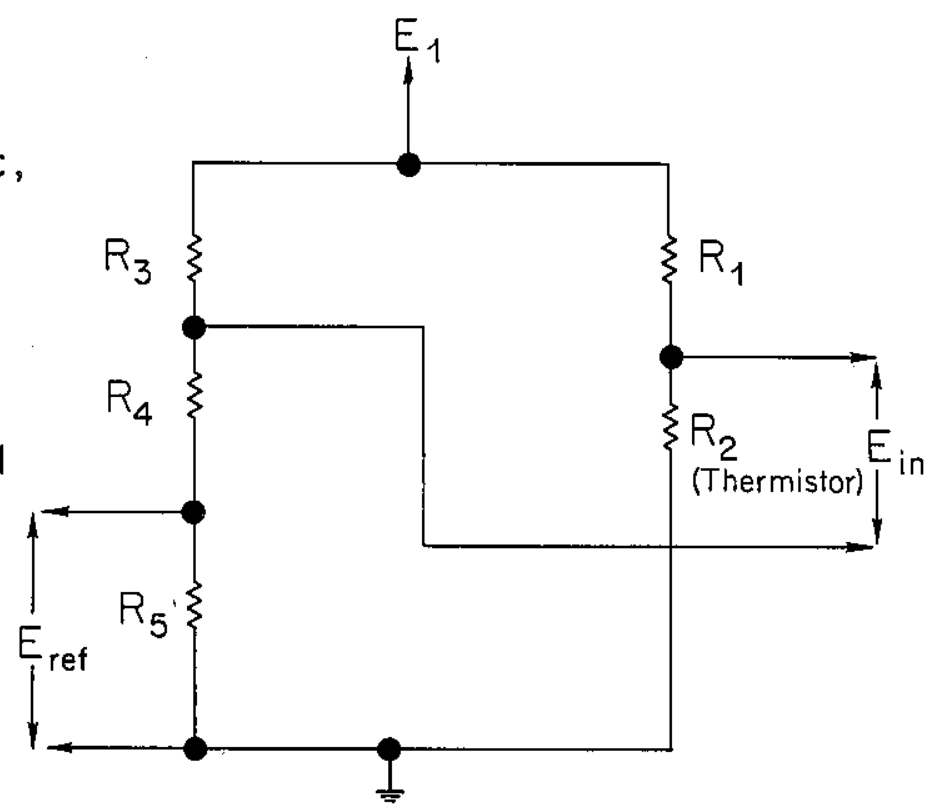

Figure D-1. Thermistor bridge circuit.

or $\quad R_{2}=8.715\left[\frac{\left(3.734039+\frac{\text { count }}{2048}\right)}{\left(3.023975-\frac{\text { count }}{2048}\right)}\right]$

with the following circuit values (Fig. D-1):

$$
\begin{aligned}
R_{1} & =8.715 \mathrm{~K} \\
R_{2} & =\text { thermistor resistance } \\
R_{3} & =2.84671 \mathrm{~K} \\
R_{4} & =2.57377 \mathrm{~K} \\
R_{5} & =0.94135 \mathrm{~K} \\
\frac{E_{1 n}}{E_{\text {ref }}} & =\frac{\text { count from A/D }}{2048}
\end{aligned}
$$


APPENDIX E. CURVE FITTING TO THERMISTOR CALIBRATIONS

We have found that the thermistor calibrations are fit very well (to better than a few millidegrees over a $60^{\circ}$ range) by a 3-parameter equation (Steinhart and Hart, 1968)

$$
\begin{aligned}
T^{-1} & =A+B \ln R+C(\ln R)^{3} \\
\text { where } T & =\text { temperature }(K) \\
R & =\text { thermistor resistance (ohms) }
\end{aligned}
$$

$A, B, C$ are constants to be determined for each thermistor. Obviously, at least 3 calibration values are needed to determine the 3 constants in the equation, but usually we have an overdetermined problem of finding the best solution for more than 3 values. This solution is found by the usual leastsquares method. Notice that the squared term of the power series is absent, so the usual curve fitting routines for a power series are not used. The least-squares method for this equation, assuming equal weighting of calibration values, is derived as follows:

We simplify the notation by solving for the equation

$$
x=A+B y+C y^{3}
$$

where we have substituted $x$ for $T^{-1}$, and $y$ for $\ln R$. Then we want to determine the constants $A, B$, and $C$ such that $\sum^{n}\left(A+B y+C y^{3}-x\right)^{2}=$ minimum for $n$ calibration values. This condition is met by differentiating this expression with respect to each of the constants and setting equal to zero:

$$
\begin{aligned}
& \frac{\partial}{\partial A}=2 \sum\left(A+B y+C y^{3}-x\right)=0 \\
& \frac{\partial}{\partial B}=2 \sum\left(A+B y+C y^{3}-x\right) y=0 \\
& \frac{\partial}{\partial C}=2 \sum\left(A+B y+C y^{3}-x\right) y^{3}=0 \\
& \text { where the summation over } n \text { is assumed }
\end{aligned}
$$

or:

$$
\begin{aligned}
& \sum\left(A+B y+C y^{3}-x\right)=0 \\
& \sum\left(A y+B y^{2}+C y^{4}-y x\right)=0 \\
& \sum\left(A y^{3}+B y^{4}+C y^{6}-y^{3} x\right)=0
\end{aligned}
$$


Re-arranging terms:

$$
\begin{aligned}
& A n+B \sum y+C \sum y^{3}-\sum x=0 \\
& A \sum y+B \sum y^{2}+C \sum y^{4}-\sum y x=0 \\
& A \sum y^{3}+B \sum y^{4}+C \sum y^{6}-\sum y^{3} x=0
\end{aligned}
$$

Rewriting in matrix format:

$$
\left[\begin{array}{lll}
n & \sum y & \sum y^{3} \\
\sum y & \sum y^{2} & \sum y^{4} \\
\sum y^{3} & \sum y^{4} & \sum y^{6}
\end{array}\right] \cdot\left[\begin{array}{l}
A \\
B \\
C
\end{array}\right]=\left[\begin{array}{l}
\sum x \\
\sum y x \\
\sum y^{3} x
\end{array}\right]
$$

or:

$$
\left[D_{i j}\right] \cdot\left[B_{1}\right]=\left[E_{i}\right]
$$

The desired solution is therefore:

$$
\left[B_{1}\right]=\left[D_{i j}\right]^{-1} \cdot\left[E_{1}\right]
$$


APFENOIX F. PROIGRAM LISTINGS FOR THE TEMPERATURE RECORDER

1. INSTRUCTI ONS FOR TREC:

NAME: TREC/AVRG

PURPOSE: To control operation of DSDP Coring Tool Temperature Recorder

MACHINE: 1802 COSMAC

SOURCE LANGUAGE: RCA CSDP Assembler

DESCRIPTION :

The Coring Tool Temperature Recorder is a miniature data aquisition system packaged in a custom hybrid integrated circuit. It was developed at WHOI for the purpose of measuring in situ temperature of deep ocean sediments, from the cutting shoe (tip) of a Hydraulic Piston Coring (HPC) too1. The recorder contains an 1802 microprocessor, 3k bytes of static RAM, a serial I/O port, and an A/D converter on a substrate approximately $0.55^{\prime \prime} \times 2.7^{\prime \prime}$. An external sensor (nominally a thermistor bridge) and battery pack complete the recorder, which has the capability to aquire 1200 to 1500 fourteen bit data points at intervals of 0.2 seconds to several hours.

TREC is an operating program designed to drive this recorder. During initialization it allows the user to interactively specify one to eight sets of data samples to be aquired by the recorder, with independent turn on delay, sample interval, and sample count for each sample set. After initialization the sample parameters are echoed back to the user for verification, and the recorder's program memory is checksummed. Upon user command TREC enters aquisition mode, and each sample set is aquired using the specified delay, sample count, and sample interval parameters. TREC terminates aquisition and places the recorder in a low power idle mode after all specified sample sets have been aquired, or when the available data memory becomes full. After recovery of the recorder, the recorder $C P U$ is reset and TREC outputs the stored data values to an external data storage device.

OPERATION:

LOADING

1. Place the recorder in Load mode and load the TREC binary code file into the recorder from the support computer. Detailed instructions for this proceedure will be provided for each type of support computer which is used.

2. Reset the recorder CPU to begin execution of TREC. Again, instructions will vary depending upon the support computer provided.

\section{INITIALIZATION}

3. TREC will prompt the user for three parameters for each sample set: the number of samples, the sample interval, and the delay period prior to sampling. Each parameter is input as a $0-4$ digit hex number followed by a carriage return, as further specified in the "Input" section below. These sample parameters are stored in the recorder memory and later used to control operation of the recorder during data aquisition. The sample parameter prompts are: 
\# SAMPLES ? Input the desired hex number of samples for this sample set. The sum of samples for all sample sets should be less than 1380 decimal ( 564 hex). Entering a value of zero samples terminates the initialization proceedure and causes verification to begin.

INTERVAL ? Input the desired hex sample interval for this sample set, in tenths of seconds, from a minimum of 2 up to a maximum of 65535 decimal (2-FFFF hex). Note: a specified interval of, 1 ( $0.1 \mathrm{sec}$ ) will result in an actual value of 65536 $(6553.6 \mathrm{sec})$.

DELAY ? Input the desired hex value of turn on delay prior to this sample set, in seconds, from 0 to 65536. Turn on delay is the delay before aquiring the samples specified by \#⿰ SAMPLES and INTERVAL.

\section{VERIFICATION :}

When a value of zero samples is input during initialization, input stops and verification begins. Each of the sets of sample parameters is read from memory and output for inspection by the user. A simple checksum is computed over program memory and output also. The user is then prompted for further action. A typical verification output would be:

$\begin{array}{lll}\text { \#SAMPLES }=0080 & \text { INTERVAL }=0064 & \text { DELAY }=1 \text { C02 } \\ \text { \#SAMPLES }=0400 & \text { INTERVAL }=000 \mathrm{~A} & \text { DELAY }=0000 \\ \text { \#SAMPLES }=00 \mathrm{D} 4 & \text { INTERVAL }=0032 & \text { DELAY }=0000 \\ & & \\ \text { CHECKSUM }=0058 & \text { ACTION ? }\end{array}$

(This would specify an inital delay of 120 minutes followed by 128 samples at 10 second intervals, 1024 samples at 1 second intervals, and 228 samples at 5 second intervals, followed by power down.)

Examine each displayed parameter to be sure it is correct, and compare the checksum to the correct value for the TREC version in use. If all information is correct, typing a capital " $G$ " in response to the "ACTION ?" prompt will cause TREC to enter aquisition mode and begin the first delay period. Typing " $G$ " may be delayed for as long as necessary, to synchronize the pending aquisition cycle with external events such as HPC operation.

If any of the displayed sample parameters are incorrect or must be changed, TREC may be re-initialized by typing a carriage return in response to the "ACTION" prompt, and returning to step 3 above.

If the checksum does not match the correct value given for the TREC version in use, a data error has occurred during or after program load. Do not use a program with a checksum error. Reload TREC from the support computer and start over. 
During the delay period prior to sampling, TREC outputs an "Q" symbol every second to verify correct program operation. Once the "C" is observed the instrument may be sealed and deployed using appropriate proceedures. The tilt switch is active during the delay periods, as follows: If the recorder is horizontal continuously for more than 1 minute, the delay timing stops ("C" stops also). Delay timing restarts from the initially specified delay value for the current sample set, after the recorder has been restored to vertical continuously for 5 minutes.

After the specified delay period has elapsed the A/D converter is powered up and the number of samples specified for the current sample set is aquired, at the interval specified. After sampling, the number of samples in the next sample set is read from memory. If it is zero, the recorder is powered down and the CPU executes an "Idle" instruction until instrument recovery. If the number is not zero, the remaining sample parameters for the next sample set are read from memory and the next delay period begins. The A/D converter is powered down during delay unless the delay is zero seconds. If data memory becomes full during sampling further sampling is inhibited and the recorder is powered down as usual.

PLAYBACK:

Upon recovery the recorder will normally have exited Aquisition mode and be powered down with the CPU reset. After power up and release from reset TREC will dump the stored data as a sequence of 4 hex digit records, one for each sample aquired. When all samples have been dumped the message "STOP" is output and the recorder is powered down. The data playback sequence may be restarted after power down by again resetting the recorder, using the playback routine on the support computer.

\section{INPUT FORMATS:}

All input is serial asynchronous ASCII at 1200 baud; 8 data bits, one stop bit, no parity bit.

SAMPLE PARAMETERS. Each parameter is input as a zero to four digit hex number followed by a carriage return. Valid hex digits are echoed back to the user input device; invalid or unrecognized characters are not. The carriage return is not echoed. Valid digits are 0-9 and $\mathrm{A}-\mathrm{F}$. If no digits are input before the carriage return a default value of zero is assumed for the parameter. Only the last 4 digits entered are significant, so that typing errors may be corrected by typing unit1 the last 4 digits represent the desired value and then typing carriage return.

OUTPUT FORMAT:

All output is serial asynchronous ASCII at 1200 baud; 8 data bits, one stop bit, no parity bit. 
PROMPTS.

The prompt "非SAMPLES?" is output upon initial reset, followed by the "INTERVAL?" and "DELAY?" prompts. The set of three prompts is repeated for each sample set specified. The prompt formats are:

(CR) (LF) 非SAMPLES? ( $\mathrm{SP}$ ) (ETX)

(SP) (SP) (SP) INTERVAL? (SP) (ETX)

(SP) (SP) (SP)DELAY? (SP) (ETX)

where $L F=$ line feed (hex $O A), C R=$ carriage return (hex $O D$ ), $S P=$ space $($ hex 20), and ETX = End-Of-Text (hex 03). A 200 millisecond pause follows each $C R$ transmitted by TREC.

VERIFICATION. A double linefeed is output on entry to the verification routine. A verification record is output for each set of sample parameters entered during initialization. Each record has the format

$$
\text { \#SAMPLES }=\text { HHHH INTERVAL }=\text { HHHH DELAY }=H H H H(C R)(L F)
$$

where HHHH is a four digit hex number. After the last record the checksum is output in the format

CHECKSUM $=$ HHHH ACTION? $(\mathrm{SP})($ ETX).

AQUISITION. During the delay intervals the character "Q" is output once per second. This output stops during tilt switch waits and during the actual sampling process.

PLAYBACK. After recovery and CPU reset the recorded data is output. Each 14 bit sample is output as four hex digits $H_{i}$ in the following format

$$
\mathrm{H}_{3} \mathrm{H}_{2} \mathrm{H}_{1} \mathrm{H}_{0}(\mathrm{LF})(\mathrm{CR})
$$

where: $\mathrm{H}_{3}$ contains the overrange (bit 2) and polarity (bit 3) bits; bits 0 and 1 of this digit should be ignored. $\mathrm{H}_{2}$ contains bits 11 (MSB) through 8 of the $\mathrm{A} / \mathrm{D}$ output, $\mathrm{H}_{\mathrm{I}}$ contains bits 7 through 4 , $\mathrm{H}_{0}$ contains bits 3 through 0 (LSB).

Each carriage return is followed by a 200 millisecond pause. After the last aquired sample has been output, the end of data message is output:

$$
\operatorname{STOP}(L F)(C R)
$$

\section{ERROR MESSAGES :}

TREC performs minimal input validity checking due to its small size. If a non hex character is supplied during data input, that character will not be echoed to the user. No error message is output. Input values are not checked for reasonableness or consistency. 
1. The sum of the number of samples in all sample sets should not exceed 1380 decimal. No harm will result from specifying a greater number of samples, but only the first 1380 samples will be aquired.

2. Specifying a sample interval of " 1 " $(0.1 \mathrm{sec})$ will result in an actual sample interval of 6553.6 seconds.

\section{SUBROUTINES REQUIRED: (all internal to TSEC package)}

The first set of routines listed below are memory resident before, during, and after aquisition.

$\begin{array}{lll}\text { PLAYBK } & - & \text { dumps recorded samples. } \\ \text { OUTDAT } & - & \text { outputs a } 4 \text { hex digit number. } \\ \text { MAIN } & - & \text { aquisition control program. } \\ \text { DLAY } & - & \text { turn on delay; tilt switch. } \\ \text { AQUI } & - & \text { sample and sample interval control. } \\ \text { GETDAT } & - & \text { gets one sample from A/D. } \\ \text { TSEC } & - & \text { precision } 0.1 \text { second timing routine. } \\ \text { OUTCHR } & - & \text { outputs a variable length ASCII string. }\end{array}$

The following routines are loaded into the data area of memory and are executed once during initialization. They are overlaid (destroyed) by data during the actual aquisition process.

$\begin{array}{lll}\text { INIT } & \text { - } & \text { initializes registers, prompts for parameters. } \\ \text { VERIFY } & - & \text { outputs parameters, computes checksum. } \\ \text { INDAT } & - & \text { reads and converts } 4 \text { digit ASCII hex numbers. }\end{array}$

\section{DATA STRUCTURES :}

Most operating parameters, counters, and pointers are stored in the internal CPU registers. There are three simple data structures:

1. STACK. Used for temporary storage during computations and for holding data to be output with the OUT instruction.

2. PARAMETER STRINGS. There may be one to eight six-byte strings. Each string consists of three 16 bit (two byte) values stored high byte first: number of samples, interval, and delay. A value of zere samples indicates the end of the string area.

3. DATA VALUES. Two-byte data values are stored high byte first, beginning directly above the last parameter string and continuing up through the highest location in the available memory.

TIMING:

All TREC timing routines are based on a $38.400 \mathrm{kHz}$ CPU clock. Assuming this clock frequency, DLAY and AQUI will execute their respective delay and sample intervals with an accuracy of $.005 \%$. At the beginning of each new sample set there will be an uncompensated delay of 16 milliseconds while the new sample parameters are accessed. 
PROGRAMMER :

Ed Mellinger

DATE :

25 April 1982

\section{Appendix 1}

AVRG :

The program AVRG is a modified version of TREC designed for use when noise is a problem in the A/D converter input. AVRG operates in a manner similar to TREC during all modes of operation, with the exception of :

INITIALIZATION.

The INTERVAL value should be specified in seconds rather than in tenths of seconds as with TREC. A value of 1 ( $1 \mathrm{sec}$ ) is acceptable to AVRG, but not to TREC.

The maximun total number of samples in all sample sets is 1325 decimal (52D hex).

AQUISITION.

The symbol "S" is output once per second while in aquisition mode. After one specified sample interval ( 1 to $65536 \mathrm{sec}$ ) has elapsed, a set of eight samples is aquired over a period of one second and averaged to produce a single value. This value is stored in data memory in the usual fashion. AVRG :

The following minor irregularities have been noted in the operation of

1. The sample interval is actually 1.0023 times the specified sample interval, in seconds.

2. The first sample following a delay period will be erroneous due to the $A / D$ converter turn-on time constant. 


\section{SOLRCE CODE FOR TEMPERATURE RECOROER a. TFEE:}

AVOCET SYSTEMS 1882 CROSS-ASSEMBLER - VERSION 1.48

SOLRCE FILE NAME: TREC.ASY

;OSOP CCRING TOOL TEMPERATURE RECORDER OPERATING SOFTHARE

;ED MELLINGER 11 APRIL 1982

¡UPDATES: 21 APRIL 1982

"TREC" IS DHA LOADED INTO LOWEST 680 BYTES OF MEMORY. CPU ;RESET CAUSES JIMP TO "INIT' WHICH INITIALIZES CPU REGISTERS AND ;PRQMPTS FOR SAMPLE-SET PARAMETERS. UP TO 8 SAMPLE SETS MAY BE ; SPECIFIED, EACH WITH INDEPENDENT TURN ON DELAY (B-65536 SEC), ;SAMPLE INTERYAL (8-6553.6 SEC) AND NUMBER OF SAMPLES (1-1488). ;MAX TOTAL NLMBER OF SAMPLES IS 1489. ENTERING A VALUE OF ZERO ;SAYPLES TERMINATES "INIT" AND CAUSES "VERIFY" TO BE EXECUTED. ;"VERIFY" PRINTS THE SAMPLE-SET PARAHETERS ENTERED OURING 'INIT" ;AND OUTPUTS AN 8 BIT LINEAR CHECKSUM ONER THE OPERATING PROGRAH ;AREA. IT THEN PROHOTS FOR USER ACTION; ENTERING "G" CAUSES ¡PROGRAM "MAIN" EXECUTION TO BEGIN, ANY OTHER CHARACTER CAUSES A ;RESTART AT 'INIT'.

;"MAIN" READS THE SAMPLE-SET PARAMETERS STORED IN MEMORY BY ;"INIT" AND INITIALIZES THE SAYPLE COLNT, INTERNAL TIMER, AND ¡DELAY HORKING REGISTERS. "HAIN" THEN JUMPS TO "DLAY" WHICH ;OELAYS FOR THE SPECIFIED TIME; DURING DELAY THE TILT SWITCH ¿OPTION IS ACTIUE AS SPECIFIED BELON. AFTER DELAY "DLAY" JUMPS TO ; "ACUI" WHICH POWERS UP THE A/D CONERTER AND AQUIRES THE ;SPECIFIED NUMBER OF SAMPLES, "AQUI" CALLS SUBROUUTINE "TSEC" TO ;IMPLEMENT THE SPECIFIED SAMPLE INTERKAL AND "GTTOAT" TO STORE ;AQUIRED DATA INTO THE DATA MEMORY AREA. WHEN THE SPECIFIED ;NUMBER OF SAMPLES HAUE BEEN AQUIRED "AQUI" RETUPNS TO "MAIN" ;WHERE THE NEXT SET OF SAMPLE-SET PARAMETERS IS READ. IF NLMBER ;OF SAMPLES IS ZERO THEN AOUISITION TERMINATES AND THE INSTRUMENT ;IS POWERED DOWN WITH AN 'INP $7=$ CONHAND.

0890

;AFTER INSRLMENT RECOUERY THE CPV IS RESET AND BEGINS ¡EXECUTION FROM LOCATION 8980 . NO-OP INSTRUCTIONS PLACED AT B898¿8862 BY "MAIN" CAUSE EXECUTION TO TRANSFER TO 'PLAYBK" WHICH ;OUTPUTS THE STORED DATA AS A SERIES OF RECORDS OF FOUR HEX ;CHARACTERS EACH. AFTER THE LAST DATA RECORD IS OUTPUT "PLAYBK" ;OUTPUTS THE MESSAGE 'STOP' FOLLOWED BY ETX,LF, CR, AND THEN POWERS ;DOW THE RECORDER. DATA MAY BE OUTPUT AGAIN BY RESETTING THE ;CPU.

;THE MAINLINE ROUTINES "INIT", "UERIFY", "MAIN", "DLAY", "AQUI", AND "PLAYBK" ALL EXECUTE WITH PC=8. THEY CALL THE ;UTILITY ROUTINES 'INDAT', "OUTDAT", "OUTCHR", 'TSEC', 'GETDAT", ¡AND "OUTNUM" TO IMPLEMENT VARIOUS I/O ANO TIMING FINCTIONS. EACH ;UTILITY ROUTINE HAS A SEPARATE PC ANO IS CALLED BY THE "SEP PC" ;TECHIQUE. 
ANOCET SYSTEMS 1802 CROSS-ASSEMBLER - VERSION 1.40

TREC

8980

¿ROUTINES "INIT", "UERIFY", "INDAT", AND "OUTCHR" ARE LOADED ;INTO THE DATA AREA OF MEMORY. THEY ARE EXECUTED ONCE DURING ;INITIALIZATION AND ARE ONERLAID BY DATA DURING THE ACTLAL, ;AQUISITION PROCESS. ROUTINES "PLAYBK", "MAIN", "DLAY", "AQUI", ;'GETCAT", "TSEC', AND "OUTDAT" ARE LOADED INTO LON MEMORY AND ARE ;ALAAYS PRESENT. 
AVOCET SYSTEHS 1862 CROSS-ASSEMBLER - UERSION 1.40

TREC

EQLATES

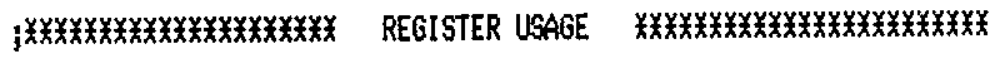

jPROGRAM COUNTERS

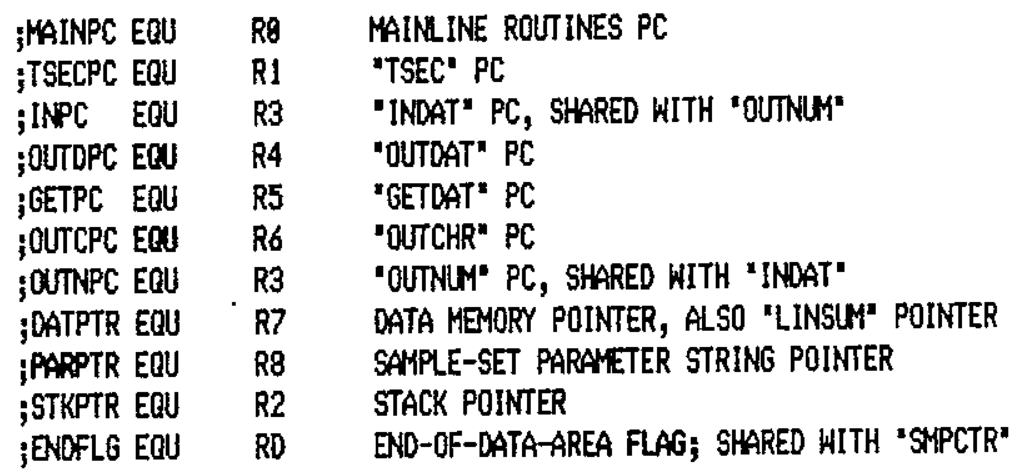

;BUFFERS AND HORKING STORAGE

;IOOAT EQU RQ DATA FROMTO I/O ROUTINES

¿DLYSTR EQU RA DELAY STOPAGE FOR "OLAY"

;INTSTR EOU R9 CURRENT SAHLE INTERMAL FOR "AQUI', SHARED WITH "OUTCHR"

;COUNTERS

;TSCTR EQU RB "TSEC" INTERRAL, COUNTER

;DLYCTR EQU RC "DLAY" INTERUAL COLNTER

;STPCTR EQU RD "AQUI" SAMPLE COUTER; SHARED WITH "ENDFLG"

ITLTCTR EQU RE "OLAY" TILT SWITCH COLNTER

;SCRATCHAAD

ISCRA EQU RF SCRATCHFAD REGISTER

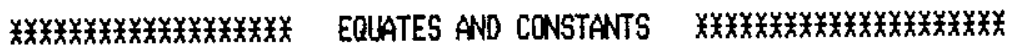

iI/0 PORT NAMES

„HBYTE EQU INPI HIGH BYTE OF A/D CONERTER

;LBYTE EQU INP2 LON BYTE OF A/D

;ADSTRT EQU INP3 ANO START SIGHAL

IUARTIN EQU INP4 UART ROUR BUFFER REGISTER

¡LLRTOT EQU OUTS UART XMITTER BUFFER REGISTER

jUNLSED EQN INP6́ UNUSED I/O SLOT

¡POWRON EQU INP7 POWER DOWN

;CONSTANTS 
AUOCET SYSTEMS 1882 CROSS-ASSEMBLER - VERSION 1.40

TREC

EQUATES

\begin{tabular}{|c|c|c|c|c|}
\hline $\begin{array}{l}9894 \\
9960 \\
0828 \\
0903\end{array}$ & $\begin{array}{l}\text { LF } \\
\text { CR } \\
\text { SP } \\
\text { ETX }\end{array}$ & $\begin{array}{l}\text { EQU } \\
\text { EQU } \\
\text { EQU } \\
\text { EQN }\end{array}$ & $\begin{array}{l}8 \mathrm{AH} \\
8 \mathrm{DH} \\
82 \mathrm{BH} \\
83 \mathrm{H}\end{array}$ & $\begin{array}{l}\text {;LINEFEED CHARACTER } \\
\text {;CARRIAGE RETURN } \\
\text { ¡SPACE } \\
\text {;END OF TEXT CHARACTER }\end{array}$ \\
\hline
\end{tabular}


AVOCET SYSTEMS 1892 CROSS-ASSEMBLER - VERSION 1.49

TREC

PROGRAM

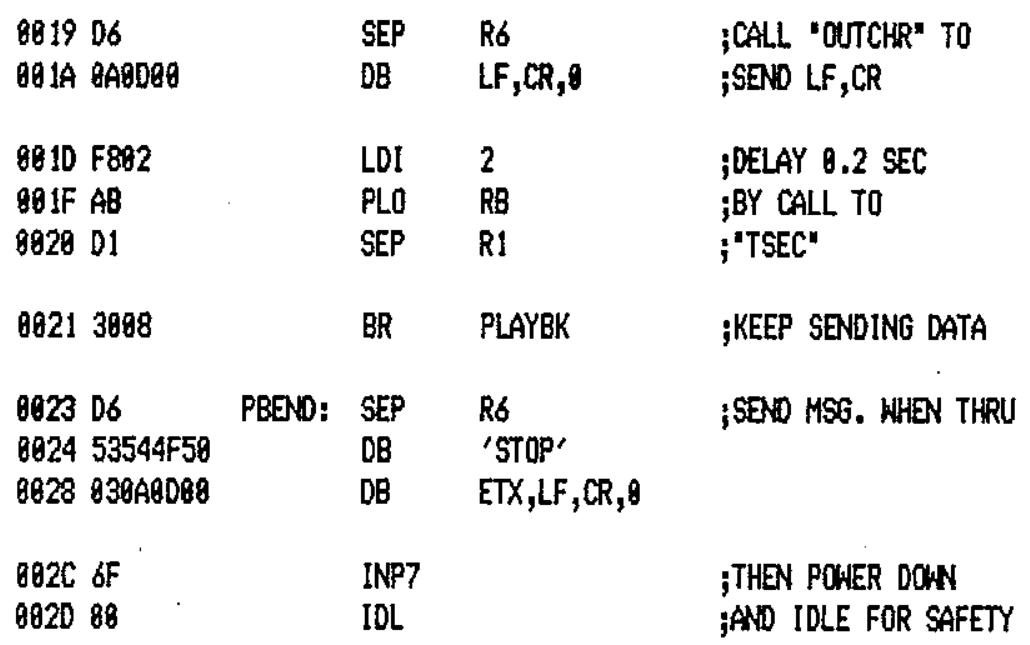

682E

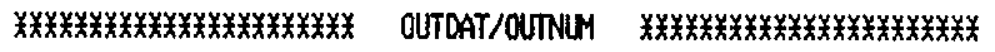

; "OUTDAT" TRANSMITS CONTENTS OF REGISTER "IODAT' AS 4 ASCII HEX DIGITS. ;"OUTDAT" ENTERED UIA 'SEP OUTDPC" AND EXITS UIA "SEP MAINPC".

8B2E DO

¡RETURN TO CALLER

$982 F 99$

8939 Fo

8931 Fo

$0832 \mathrm{~F} 6$

0633 Fo

803403

093599

$9836 \mathrm{FAOF}$

893803

863989

$893 A$ F6

$8 B 38$ F6

$993 \mathrm{~F} 6$

8830 F6

983E D3

$683 F 89$

894B FAOF

894203

$\begin{array}{lll}\text { OUTDAT: GHI } & R 9 & \text {;HIGH BYTE TO XMIT } \\ \text { SHR } & & \\ \text { SHR } & & \\ \text { SHR } & & \\ \text { SHR } & & \text {;ISOLATE HIGH NIBBLE } \\ \text { SEP } & \text { R3 } & \text {;SEND IT }\end{array}$

$6043382 E$

$\begin{array}{lll}\text { GHI } & \text { R9 } & \text {;HIGH BYTE } \\ \text { ANI } & \text { QFH } & \text {;LOW NIBBLE } \\ \text { SEP } & \text { R3 } & \text {;SEND IT } \\ \text { GLO } & R 9 & \text {;LON BYTE } \\ \text { SHR } & & \\ \text { SHR } & & \\ \text { SHR } & & \\ \text { SHR } & & \text {;HIGH NIBBLE } \\ \text { SEP } & \text { R3 } & \text {;SEND IT } \\ \text { GLO } & \text { R9 } & \text {;LOW BYTE } \\ \text { ANI } & \text { OFH } & \text {;LOW NIBBLE } \\ \text { SEP } & \text { R3 } & \text {;SENO IT }\end{array}$

BR OTEXIT \$RESET "OUTDPC" BEFORE EXIT

; "OUTNEM' -- DEDICATED SUBROUTINE FOR 'OUTDAT'. CONERTS 4 BIT BINKRY ¡UALUE IN D REG TO ASCII HEX $(g-9, A-F)$ AND XMITS UIA UART. 
AVOCET SYSTERS 1882 CROSS-ASSEYBLER - UERSION 1.40

TREC

PROGRAM

\begin{tabular}{|c|c|c|c|}
\hline 884504 & ONEXIT: SEP & 84 & ;RETURN TO "OUTDAT" \\
\hline $\begin{array}{l}9046 \mathrm{FF} 9 \mathrm{~A} \\
0948 \mathrm{C7} \\
0949 \mathrm{FCO7}\end{array}$ & $\begin{array}{r}\text { OUTNUM: SHI } \\
\text { LSNF } \\
\text { ADI }\end{array}$ & BAH & $\begin{array}{l}\text {;TEST FOR } \angle=9 \\
\text { iSKIP ADD IF YES } \\
\text {;IF A-F, ADD EXTRA }\end{array}$ \\
\hline $\begin{array}{l}884 B \text { FCJA } \\
8840 \\
8840 \\
884052 \\
864 E 344 E \\
885965 \\
885122 \\
88523845\end{array}$ & $\begin{aligned} & \text { STR } \\
& \text { ONLOOP: } \text { B1 } \\
& \text { OUTS } \\
& \text { DEC } \\
& \text { BR }\end{aligned}$ & $\begin{array}{l}\text { R2 } \\
\text { ONLOOP } \\
\text { R2 } \\
\text { ONEXIT }\end{array}$ & $\begin{array}{l}\text {;ADD NET } 39 \text { OR } \\
\text {;NET } 36 \text { TO GET } \\
\text {;ASCII CHARACTER. } \\
\text {;PUT ON STACK, NO PUSH } \\
\text {;HAIT FOR LART TRE } \\
\text {;SEND TO UART } \\
\text {;UNDO AUTOINCREMENT } \\
\text {;RESET "OUTNNC" }\end{array}$ \\
\hline
\end{tabular}

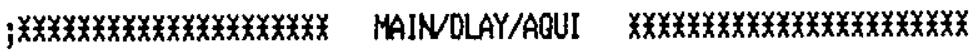

; "MAIN" READS SAMPLE-SET PARAMETERS FRCM MEMORY (POINTED TO BY ;(PARPTR") AND STORES THEM IN "SMPCTR', 'INTSTR", AND "DLYSTR", ;IF SPECIFIED NIMBER OF SAMPLES IS ZERO, AQUISITION STOPS AND THE ;RECORDER IS POHERED DOW. IF \# SAMPLES IS NONZERO MAIN" JLMPS ;TO "DLAY" FOR DELAY BEFORE AQUISITION BEGINS. AFTER DELAY, ; "DLAY" JUMPS TO "AQUI" WHERE THE SPECIFIED NMBER OF SAMPLES ARE ;AQUIRED, FOLLOWED BY A RETURN TO "MAIN" HHERE THE NEXT SAMPLE;SET'S PARAYETERS ARE READ.

6854

FMIN, DLAY, AWO AQUI EXECUTE HITH PC=HAINPC=RO. IN ;GENERAL, THETIMING OF THESE ROUTINES IS CRITICAL TO OUERALL ;TIMING ACCURACY. ANY PROGRAH CHANGES SHOLLD THEREFORE BE MADE ;WITH CARE.

\begin{tabular}{|c|c|c|c|c|}
\hline $\begin{array}{l}985448 \\
0855 \mathrm{BD} \\
985652 \\
085748 \\
8958 \mathrm{AD} \\
9859 \mathrm{F1} \\
985 A \text { BAC } \\
985 \mathrm{C}\end{array}$ & MAIN: & $\begin{array}{l}\text { LDA } \\
\text { PHI } \\
\text { STR } \\
\text { LDA } \\
\text { PLO } \\
\text { OR } \\
\text { BNZ }\end{array}$ & $\begin{array}{l}\text { R8 } \\
\text { RD } \\
\text { R2 } \\
\text { R8 } \\
\text { RD } \\
\text { NOIDLE }\end{array}$ & $\begin{array}{l}\text {;GET SAMPLE HB } \\
\text {;STORE } \\
\text {;ALSO SAVE TEMP. } \\
\text {;GET I SAMPLES LB } \\
\text {;STORE } \\
\text {;MERGE LB AND HB } \\
\text {;KEEP GOING IFCOO } \\
\text {;ELSE POWER DOW }\end{array}$ \\
\hline
\end{tabular}

;BEFIRE POWERING DOWN PUT "NO-OPG" AT 8888-8882; TO ALLOW ; PLAYGK" TO BE EXECUTED AFTER NEXT CPU RESET. (NOTE D=8 HERE)

885C BF

$9850 \mathrm{AF}$

805E F8C4

$08685 F$

0661 IF

$98625 F$

$0063 \mathrm{IF}$

$\begin{array}{ll}\text { PHI } & \text { RF } \\ \text { PLO } & \text { RF } \\ & \\ \text { LDI } & \text { NOINST } \\ \text { STR } & \text { RF } \\ \text { INC } & \text { RF } \\ \text { STR } & \text { RF } \\ \text { INC } & \text { RF }\end{array}$

;FIRST NEED ¡POINTER TO 6988

;GET "NOP" OPCODE

¿PUT AT 9808

;AND AT 8901 
ANOCET SYSTEAS 1802 CROSS-ASSEMBLER - VERSION 1.40

TREC

PROGRAY

$8864 \mathrm{SF}$

STR RF

;ANO AT 9882

;ALSO SAUE LAST DATA LOCATION AS FLAG FOR "PLAYBK"

\begin{tabular}{|c|c|c|c|}
\hline $\begin{array}{l}906597 \\
8066 \text { BD } \\
896787 \\
8068 \text { AD }\end{array}$ & $\begin{array}{l}\text { GHI } \\
\text { PHI } \\
\text { GLO } \\
\text { PLO }\end{array}$ & $\begin{array}{l}\text { R7 } \\
\text { RD } \\
\text { R7 } \\
\text { RD }\end{array}$ & \\
\hline $\begin{array}{l}80697 \mathrm{~A} \\
886 \mathrm{~A} 6 \mathrm{~F} \\
896 \mathrm{~B} 98\end{array}$ & $\begin{array}{l}\text { REQ } \\
\text { INP7 } \\
\text { IDL. }\end{array}$ & & $\begin{array}{l}\text { iTLRN OFF AVD } \\
\text {;POWER DOWN } \\
\text {;IOLE TO BE SURE }\end{array}$ \\
\hline
\end{tabular}

;IF \# SAMPLES $O B$ GET INTERNAL AND DELAY PARAMETERS ALSO

\begin{tabular}{|c|c|c|c|}
\hline $\begin{array}{l}986 C 48 \\
986 D \text { B9 } \\
986 E \text { E } 48 \\
906 F \text { A9 }\end{array}$ & $\begin{array}{r}\text { NOIDLE: LDA } \\
\text { PHI } \\
\text { LDA } \\
\text { PLO }\end{array}$ & $\begin{array}{l}\text { R8 } \\
\text { R9 } \\
\text { R8 } \\
\text { R9 }\end{array}$ & $\begin{array}{l}\text {;GET AND STORE } \\
\text {;SAMPLE INTERUAL } \\
\text {;HB THEN LB. }\end{array}$ \\
\hline $\begin{array}{l}967848 \\
0971 \quad B A \\
697248 \\
8973 \quad 4 A\end{array}$ & $\begin{array}{l}\text { LDA } \\
\text { PHI } \\
\text { LDA } \\
\text { PLO }\end{array}$ & $\begin{array}{l}R 8 \\
R A \\
R 8 \\
R A\end{array}$ & $\begin{array}{l}\text { ¡GET AND STORE } \\
\text {;DELAY TIME } \\
\text {;HB THEN LB. }\end{array}$ \\
\hline
\end{tabular}

;FALL THRU INTO "OLAY" WHEN all Parameters are LOADED. "DLAY" "MONES "DLYSTR" INTO 'DLYCTR", DECREMENTS "DLYCTR' CNCE PER ;SECONO INTIL "DLYCTR" IS ZERO, THEN JLMPS TO "AOUI". TILT ;SWITCH IS SAMPLEO EVERY SECOND DURING DELAY. IF SHITCH OPENS ;FOR 68 CONSECUIIUE SAYPLES (1 MINUTE) THEN "RESTRT" IS EXECUTED. ; "RESTRT" RESETS DELAY COUNTER TO ITS INITIAL VALLE ("DLYSTR" IINTO "DLYCTR"), THEN SAMPLES TILT SHITCH EVERY 4 SECONOS. IF ;SNITCH CLOSES FOR 75 CONSECUTIUE SAMPLES (5 MINUTES) THEN "DLAY" ¿IS EXECUTED AND DELAY STARTS OUER.

¡TIMING IN THESE ROUTINES IS CRITICAL; MAKE CHANGES CAREFULLY.

\begin{tabular}{|c|c|c|c|c|}
\hline $\begin{array}{l}98749 A \\
9875 \mathrm{BC} \\
88768 \mathrm{~A} \\
8677 \mathrm{AC}\end{array}$ & DLAY: & $\begin{array}{l}\text { GHI } \\
\text { PHI } \\
\text { GLO } \\
\text { PLO }\end{array}$ & $\begin{array}{l}R A \\
R C \\
R A \\
R C\end{array}$ & $\begin{array}{l}\text {;GET DELAY TIME } \\
\text { \$FROM STORAGE } \\
\text { IINTO } \\
\text {;HORKING COUNTER. }\end{array}$ \\
\hline $\begin{array}{l}9078 \text { F83C } \\
897 A \text { AE }\end{array}$ & & $\begin{array}{l}\text { LDI } \\
\text { PLO }\end{array}$ & $\begin{array}{l}\text { 83CH } \\
\mathrm{RE}\end{array}$ & $\begin{array}{l}\text {;68 SEC TIMEOUT } \\
\text {;TO DETECT TILT. }\end{array}$ \\
\hline
\end{tabular}

; ("GLITCH" IS THE RE-ENTRY POINT IN CASE OF A SPURIQUS CPU RESET ;DURING "DLAY" OR "AQUI"; IT IS ENTERED AFTER CPU RESET UIA A ;LONG BRANCH PLACED AT $6988-8682$ BY 'INIT'. RECONERY FROM ;SPURIOUS RESETS IS POSSIBLE DURING "OLAY" AND "AQUI", WITH ;POSSIBLE LOSS OF ONE DELAY OF AQUISITION CYCLE. GITCHES DLRING ;"MAIN" ARE FATAL SINCE "PARPTR" WILL BE INCORRECTLY POSITIONED 
ANOCET SYSTEMS 1882 CROSS-ASSEMBLER - VERSION 1.40

TREC

PRQGRAM

;UPON RE-ENRY.)

9078 E2 GLITCH: SEX R2 FFIX R(X) AFTER RESET

;TEST FOR OELAY FINISHED; TEST FOR TILT

\begin{tabular}{|c|c|c|c|}
\hline $\begin{array}{l}987 C \text { 9C } \\
897052 \\
897 E \text { 8C } \\
887 F \text { F1 } \\
898832 B 4\end{array}$ & $\begin{array}{r}\text { DYLOOP: GHI } \\
\text { STR } \\
\text { G.O } \\
\text { OR } \\
\text { BZ }\end{array}$ & $\begin{array}{l}\mathrm{RC} \\
\mathrm{R} 2 \\
\mathrm{RC} \\
\\
\text { AQUI }\end{array}$ & $\begin{array}{l}\text {;TEST DELAY } \\
\text {;BY MERGING } \\
\text {;'DLYCTR: HB+LB. } \\
\text {;IF BOTH ZERO } \\
\text {;GO DO AOUUI. }\end{array}$ \\
\hline $\begin{array}{l}\theta 082 \text { 8E } \\
8983 \text { 32A2 }\end{array}$ & $\begin{array}{l}\text { GLO } \\
B Z\end{array}$ & $\begin{array}{l}\text { RE } \\
\text { RESTRT }\end{array}$ & $\begin{array}{l}\text { ¡ELSE TEST FOR } \\
\text { ¡TILY, RESTART IF YES }\end{array}$ \\
\hline
\end{tabular}

;OUTPUT "Q" FOR TIMING, DELAY ONE SECOND, CHECK TILT SHITCH

0885

8685 6E 8886 F849

698852

608965

B8\&A 22

$068 \mathrm{2C}$

$898 \mathrm{C} 889$

g日gE AB

608F D1

$8990 F 849$

8892 FFB1

$09947 \mathrm{~A}$

09953492

8697 3F9E

0999 F83C

8998 AE

$099 \mathrm{C} 387 \mathrm{C}$

009E 2E

909F 7A

O8AB $397 C$
DTILT: DEC RE

REQ

BR DYLOOP
;IF ALL OK, ;OO TIME MARKS ;XNIT MARK VIA ¡UART EUERY SEC.

;INDO AUTOINCR.

¡DEC DELAY COLNTER REG ¡COARSE DELAY, ;9.9 SEC VAI ;'TSEC' CALL.

;FINE DELAY (49H=730) ;TO FILL OUT OYLOOP ;(ALSO OFF A/D) ;TO EXACT 1.8 SEC

¡CHECK TILT SH, ¡IF NO TILT, ;RESET TILT COLNTER ;KEEP DELAYING.

;IF TILT, DEC COUNTER. ; $(2$ CYCLE NO-OP) ¡KEEP DELAYING.

;"RESTRT" RESETS THE DELAY COUNTER ("DLYCTR") AND HAITS FOR THE ;TILT SNITCH TO OPEN AND STAY OPEN 5 MINUTES.

\begin{tabular}{|c|c|c|c|}
\hline $\begin{array}{l}\text { BQA2 F84B } \\
\text { OBA4 AE }\end{array}$ & $\begin{array}{r}\text { RESTRT: LDI } \\
\text { PLO }\end{array}$ & $\begin{array}{l}\text { 94BH } \\
\text { RE }\end{array}$ & $\begin{array}{l}; 4 B B=75 D \text { FOR } \\
; 5 \text { MIN RESTART DELAY. }\end{array}$ \\
\hline BQA5 8E & RSLOOP: GLO & RE & :TEST FOR INTILT \\
\hline
\end{tabular}


ANOCET SYSTEMS 1802 CROSS-ASSEMLER - VERSION 1.46

TREC

PROGRAY

98463274

88A8 F828

BQAA AB

g8AB DI

B8AC 3781

B8AE F84C

GQBB AE

BZ DLAY

¡RE-START DELAY IF YES

98B1 2E

$098230 A 5$

$\begin{array}{ll}\text { LDI } & 928 H \\ \text { PLO } & \text { RB } \\ \text { SEP } & \text { R1 }\end{array}$

;4.8 SECOND

ICOARSE OELAY ONLY

;UIA "TSEC" CALL.

$\begin{array}{ll}\text { B4 } & \text { NOTILT } \\ \text { LDI } & \text { O4CH } \\ \text { PLO } & \text { RE }\end{array}$

;TEST TILT SH

IIF OPEN, RESET

;TILT COLNTER ( +1$)$

NOTILT: DEC RE

BR RSLOOP ;CONTER AND LOOP.

; 'AQUI" IS ENTERED FRON "DLAY". "AQUI' CHECKS SAMPLE COUNTER ;REG. "SAPCTR" FOR 2ERO, RETUNONS TO HAIN IF YES. IF NO, "AQUI" ¿POWERS UP A/D, INITIALIZES "TSEC" COUNTER WITH SAMPLE INTERYAL ;ANO CALLS "TSEC". AFTER 'TSEC' TIMES THE SPECIFIED INTERNAL, ;'AQUI" STARTS A/D CONERSION AND CALLS "GETDAT" TO TRANSFER ¡CONERTER DATA TO MEMORY IN DESIFED FOPAAT (PACKED OR (NPACKED). ;AFTER TRANSFER, "AQUI" CHECKS DATA POINTER "DATPTR" AND PREVENTS iIT FROM INCREMENTING BEYOND THE END OF DATA MEMORY (LOCATION ;8BFF).

;'AQUI" IS A MAINLINE ROUTINE (PC=NAINPC=R日), ITS TIMING IS ;CRITICAL AND MODIFICATIONS SHOULD BE MADE HITH CARE.

¡FIRST CHECK FOR DONE

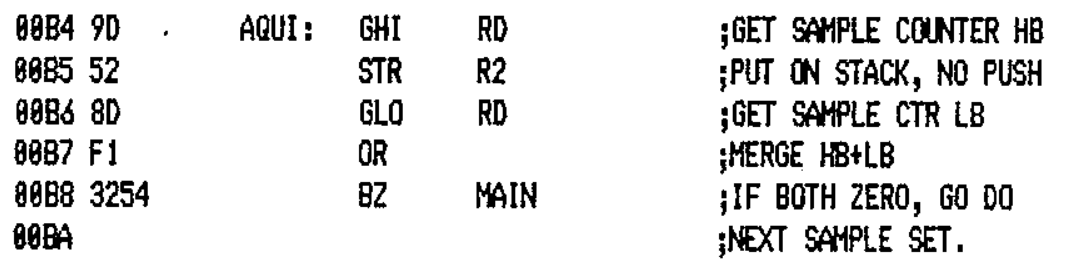

¡IF NOT DONE, SEND MARK AND WAIT I SAMPLE INTERMAL

89BA 78

B9BB $6 \mathrm{E}$

$\triangle 9 B C 20$

988099

BQBE BB

Q98F 89

B9CB AB

9日C) $2 B$

$B 8 C 2$

$80 C 201$

agc3 $6 \mathrm{~B}$

gEC4 F8 6 A

88C6 FFB1

$\begin{array}{ll}\text { SEO } & \cdot \\ \text { INP6 } & \\ \text { DEC } & \text { RD } \\ \text { GHI } & R 9 \\ \text { PHI } & \text { RB } \\ \text { GLO } & R 9 \\ \text { PLO } & \text { RB } \\ \text { DEC } & \text { RB } \\ \text { SEP } & \text { RI } \\ \text { INP3 } & \end{array}$

LDI BGAH

AQLOOP; SMI 1
IPWR UP A/D

;PULSE I/O 6 LINE ¡OEC SAMPLE COUNTER \$MONE INTERNAL ;INTO "TSEC" WRKING ;COUNTER

¡LESS 0.1 SEC FOR ;LATER FINE DELAYY. ¿DELAY SPEC'D TIME iSTART A/D CONERSION

;FINE DELAY ;WAIT FOR A/D

$$
\text { F-16 }
$$


AVOCET SYSTEAS 1882 CROSS-ASSEMBLER - VERSION 1.40

TREC

PRGGRAM

$88 C B 3 A C 6$

EN AQLOOP

;GET DATA FROM A/D AND CHECK FOR DATA MEMGRY FULL

BQCA D5

$\triangle B C B$

98CB 97

OBCC FFOC

BOCE $3 B B 4$

SEP R5

;CALL 'GETDAT" TO

;HOVE DATA TO MEU

BQDO 27

800127

88D2 3654

$\begin{array}{lll}\text { GHI } & \text { R7 } & \text {;CHECK FOR } \\ \text { SMI } & \text { OCH } & \text {;DATA MEY FULL } \\ \text { BN } & \text { AQUI } & \text {;LOOP IF NO }\end{array}$

DEC R7 ;IF Y YES,

DEC R7 ;OEC POINTER

BR MAIN ;AND FORCE NEXT

;(THIS ALLOWS CORRECT TERMINATION OF AQUISITION IN "MAIN". ALL ;SAMPLE PARAMETERS MUST BE READ TO CORRECTLY POSITION "PARPTR" ;FOR PLAYBACK.)

;"GETDAT" - NONPACKING VERSION. GETS A/D DATA AND STORES ;SEQJUNTIALLYY IN MEMORY. (PACKING UERSION ALLOWS 33\% MORE ;SAMPLES IF 12-BIT SAMPLES ARE USED).

\begin{tabular}{|c|c|c|c|}
\hline 890408 & GDEXIT: SEP & $R g$ & ¡RETURN TO "AQUI" \\
\hline 890569 & GETDAT: INP1 & & ;GET A/D HB \\
\hline 880657 & STR & R7 & ;PUT IN DATA MEM \\
\hline 980717 & INC & $R 7$ & ;INC POINTER \\
\hline $98086 A$ & INP2 & & ;GET A DO LB \\
\hline 880957 & STR & $R 7$ & ¡PUT IN DATA MEM \\
\hline BODA 17 & INC & $R 7$ & ;INC POINTER \\
\hline \multirow[t]{2}{*}{$880 \mathrm{~B} 3804$} & BR & GOEXIT & ;RESTORE "GETPC" \\
\hline & \multicolumn{2}{|c|}{ 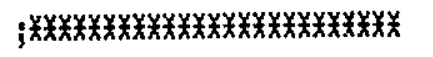 } & 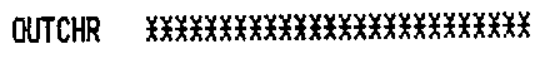 \\
\hline 8800 & \multicolumn{3}{|c|}{$\begin{array}{l}\text {;ENTERED VIA "SEP OUTCPC", OUTPUTS CHARACTER STRING } \\
\text {;POINTED TO BY "MAINPC" (NTIL A OO BYTE IS ENCONTERED, THEN } \\
\text {;RETURNS UIA "SEP HAINPC", ALTERS M(STKPTR). }\end{array}$} \\
\hline \multirow{9}{*}{ 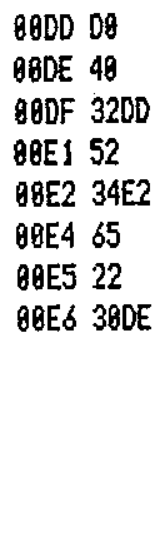 } & \multirow{5}{*}{$\begin{aligned} \text { OCEXIT: SEP } \\
\text { OUTCHR: LOA } \\
\text { BZ } \\
\text { STR } \\
\begin{aligned} \text { OCLOOP: } & \text { B1 } \\
& \text { OUT5 }\end{aligned}\end{aligned}$} & RO & ;RETURN TO CALLER \\
\hline & & $R \theta$ & $\begin{array}{l}\text {;GET CHARACTER } \\
\text { IF } 88, \text { EXIT }\end{array}$ \\
\hline & & OCEXIT & \multirow{2}{*}{$\begin{array}{l}\text {;IF } 88, \text { EXIT } \\
\text {;ELSE PUT ON STACK }\end{array}$} \\
\hline & & & \\
\hline & & OCLOOP & ;HAIT FOR UART \\
\hline & DEC & R2 & $\begin{array}{l}\text { ¿WNOO AUTOINCR. } \\
\text {;GET NEXT CHAR }\end{array}$ \\
\hline & $B R$ & OUTCHR & ;GET NEXT CHAR \\
\hline & \multicolumn{2}{|c|}{ 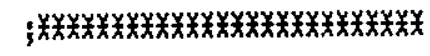 } & 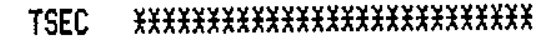 \\
\hline & \multicolumn{3}{|c|}{$\begin{array}{l}\text {;"TSEC" IS A 8.1 SEC TIMING ROUTINE. TIME FROM BEGINNING OF } \\
\text {;EXECITION OF FIRST INSTRUCTION (DEC TSCTR) TO END OF EXECUTION }\end{array}$} \\
\hline
\end{tabular}




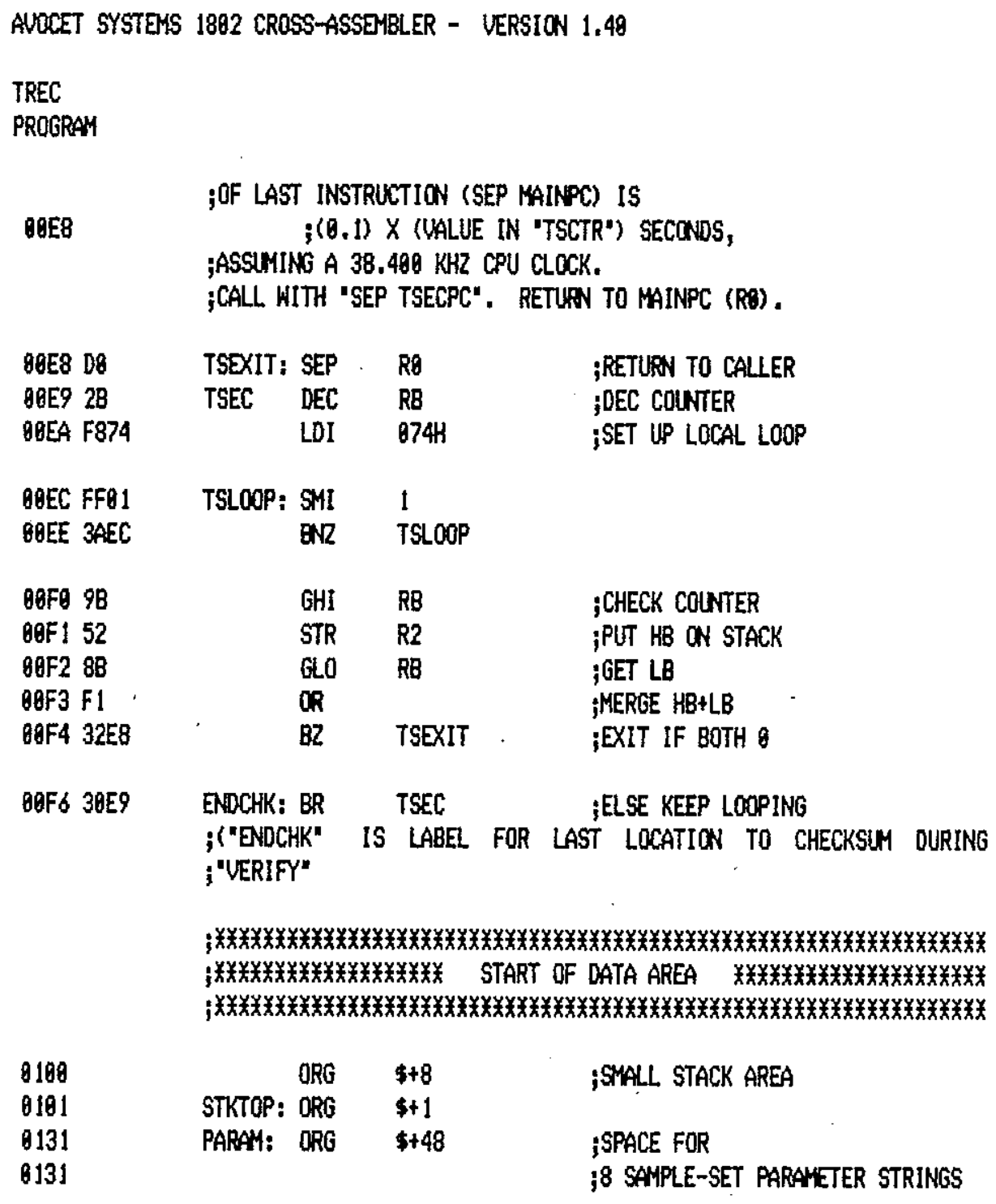

¡THE FOLLOWING ROUTINES ARE LOADED INTO THE DATA AREA AND ARE ¡EXECUTED ONCE DLRING INITIALIZATION, THEY ARE ONERLAID ; (OESTROYED) BY OATA DURING THE ACTUAL AQUISITION PROCESS.

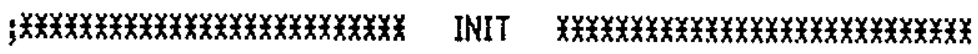
;CPU RESET, INITIALIZES REGISTERS TSECPC, INPC, OUTPC, OUTCPC, ;GETPC, STKPTR, PARPTR; SETS X=STKPTR; PONERS DOWN AND. PROMPTS 
TREC

PROGRAM
;USER FOR INPUT OF SAMPLE-SET PARAHETERS:

; \#SAMPLES? \# OF SAMPLES IN THIS SET; ZERO STOPS FURHTER INPUT. ; INTERUAL? SAMPLE INTERUAL FOR THIS SET, IN TENTHS OF SECONDS. ; DELAY? TURN ON DELAY BEFORE AOUIRING THIS SET, IN SECONDS.

;THE RESPONSE TO EACH PROMPT SHOULD BE A ONE TO FOLR CHARACTER ;HEX INTEGER FOLLOWED BY A CARRAIGE RETUPN. THE INPUT PROTOCOL IIS UT4 FOFHAT, I.E. ONLY THE LAST 4 DIGITS ARE SIGNIFICANT; ¡THUS ERRORS MAY BE CORRECTED BY TYPING UNTIL THE NUMBER IS ;CORRECT AND THEN TYPING "RETURN". ILLEGAL OR INRECOGNIZED ;CHARACTERS ARE NOT ECHOED BACK TO THE USER INPUT DEVICE.

0131

; "INIT" CONTINLES TO PROMPT FOR SAMPLE-SET PARAMETERS ¡UNIL A WALUE IS READ FOR \# SAMPLES. . UP TO 8 SETS OF ;PARAMETERS MAY BE ENTERED; MORE WILL OUERLAY PROGRAM AREAS. ;"INIT" EXITS WITH A JLMP TO "UERIFY", KEEPING PC=EAINPC=RO.

01317A, INIT: REQ ;TUPN OFF A/D

;INITIALIZE WORKING REGISTERS AS REQ'D

$8132 \mathrm{~F} 898$

$9134 \mathrm{B1}$

B135 FBEF

$0137 \mathrm{Al}$

$0138 \mathrm{~F} 882$

$813 A$ B3

813B F85A

Q13D A3

013E F808

$8149 \mathrm{~B} 4$

$8141 \mathrm{FB2F}$

8143 A4

$0144 \mathrm{~F} 898$

9146 Bó

$8147 \mathrm{FBOE}$

9149 A6

B14A F880

O14C B5

B140 F805

O14F A5

$0159 \mathrm{~F} 8 \mathrm{~B} 1$

B152 B2

$8153 \mathrm{~F} 88 \mathrm{~B}$

0155 A2

$\begin{array}{lll}\text { LDI } & \text { A.I(TSED } & \text {;INITIALIZE } \\ \text { PHI } & \text { R1 } & \text {;"TSEC" PC. } \\ \text { LDI } & \text { A.8(TSEC) } & \\ \text { PLO } & \text { RI } & \end{array}$

LDI A.1(INDAT)

PHI R3 ;'INDAT' PC.

LDI A.O(INDAT)

PLO R3

L.DI A.I (OUTDAT)

PHI R4

LDI A.8(OUTDAT)

PLO R4

LDI A.1(OUTCHR)

PHI R6

LDI A.8(OUTCHR)

PLO R6

LD1 A.1 (GETDAT)

PHI R5 ;"GETDAT" PC.

LDI A.8(GETDAT)

PLO R5

LDI A.I(STKTOP)

PHI R2

LDI A.E(STKTOP)
PLO R2
"'OUTDAT" PC.

i"OUTCHR" PC.

ISTACK POINTER

$$
\text { R2 }
$$


AVOCET SYSTEHS 1882 CROSS-ASSEABLER - VERSION 1.40

TREC

PROGRAM

$\begin{array}{llll}8156 \mathrm{F801} & \text { LDI } & \text { A. I(PARAH) } & \text {;PARAMETER } \\ 0158 \mathrm{88} & \text { PHI } & \text { R8 } & \text {;STRING POINTER } \\ 0159 \mathrm{~F} 801 & \text { LDI } & \text { A.8(PARAM) } & \\ 815 \mathrm{AB} & \text { PLO } & \text { R8 } & \\ & & & \\ 815 C \mathrm{E2} & \text { SEX } & \text { R2 } & \text {;X=STKPTR ALHAYS }\end{array}$

;PROMPT USER FOR SAMPLE-SET PARAMETERS

\begin{tabular}{|c|c|c|c|}
\hline $\begin{array}{l}8150 \text { D6 } \\
815 E \text { OA9DQ8 }\end{array}$ & $\begin{array}{c}\text { PRONPT: SEP } \\
\text { OB }\end{array}$ & $\begin{array}{l}\text { Ro } \\
L F, C R, \theta\end{array}$ & $\begin{array}{l}\text {;CALL 'OUTCHR' TO } \\
\text {;SEND LF,CR. }\end{array}$ \\
\hline $\begin{array}{l}8161 \mathrm{FB86} \\
8163 \mathrm{BB} \\
8164 \mathrm{FBg2} \\
8166 \mathrm{AB} \\
8167 \mathrm{D1}\end{array}$ & $\begin{array}{l}\text { LDI } \\
\text { PHI } \\
\text { LDI } \\
\text { PLO } \\
\text { SEP }\end{array}$ & $\begin{array}{l}8 \\
\mathrm{RB} \\
2 \\
\mathrm{RB} \\
\mathrm{R} 1\end{array}$ & $\begin{array}{l}\text {;SET UP } 8.2 \text { SEC } \\
\text {;DELAY AFTER CR }\end{array}$ \\
\hline
\end{tabular}

;PROMPT AND GET \# OF SAMPLES

\begin{tabular}{|c|c|c|c|}
\hline $\begin{array}{l}016806 \\
016923534140 \\
81713 F 298388\end{array}$ & $\begin{array}{l}\text { SEP } \\
\text { OB } \\
O B\end{array}$ & $\begin{array}{l}\text { R6 } \\
\text { '"WSAMPLES' } \\
\text { '?',SP,ETX,8 }\end{array}$ & ¡CALL 'OUTCHR' \\
\hline $\begin{array}{l}817503 \\
8176 \quad 99 \\
817758 \\
817852 \\
0179 \quad 18\end{array}$ & $\begin{array}{l}\text { SEP } \\
\text { GHI } \\
\text { STR } \\
\text { STR } \\
\text { INC }\end{array}$ & $\begin{array}{l}\text { R3 } \\
R 9 \\
\text { R8 } \\
\text { R2 } \\
\text { R8 }\end{array}$ & $\begin{array}{l}\text {;CALL "INDAT" } \\
\text {;GET RETURN HB } \\
\text {;STORE IN MEMORY } \\
\text {;ALSO ON STACK } \\
\text {;INC MEM PTR }\end{array}$ \\
\hline $\begin{array}{l}817 \mathrm{~A} 89 \\
817 \mathrm{~B} 58 \\
817 \mathrm{C} 18 \\
8170 \mathrm{F1} \\
917 \mathrm{E} 32 \mathrm{AD} \\
8188\end{array}$ & $\begin{array}{l}\text { GLO } \\
\text { STR } \\
\text { INC } \\
\text { OR } \\
\text { B2 }\end{array}$ & $\begin{array}{l}\text { R9 } \\
\text { R8 } \\
\text { R8 }\end{array}$ & $\begin{array}{l}\text {;GET RETUPN LB } \\
\text {;STORE IN MEYORY } \\
\text {;INC MEY PTR } \\
\text {;MERGE HB AND LB } \\
\text {;IF 8, NO MORE INPUT. } \\
\text {;ELSE GET INTL, DELAY. }\end{array}$ \\
\hline
\end{tabular}

¡PROAPT AND GET SAMPLE INTERAL

$\begin{array}{llll}8188 \text { D6 } & \text { SEP } & \text { R6 } & \text {;SEND PROMPT } \\ 8181282828 & \text { DB } & \text { SP,SP,SP } & \\ 8184494 E 5445 & \text { OB } & \text { 'INTERNAL' } & \\ 818 C 3 F 288390 & \text { DB } & \text { '?',SP,ETX,8 } & \\ & & & \\ 819803 & \text { SEP } & \text { R3 } & \text {;GET INPUT } \\ 819199 & \text { GHI } & \text { R9 } & \\ 819258 & \text { STR } & \text { R8 } & \\ 819318 & \text { INC } & \text { R8 } & \\ 819489 & \text { GLO } & \text { R9 } & \\ 819558 & \text { STR } & \text { R8 } & \end{array}$


AUOCET SYSTENS 1882 CROSS-ASSEMBLLR - UERSION 1.48

TREC

PROGRAM

019618

INC R8

¡PRONPT AND GET TURN ON DELAY TIME (DELAY BEFORE SAWPLING STARTS)

\begin{tabular}{|c|c|c|c|c|}
\hline $\begin{array}{l}8197 \text { D6 } \\
9198202829 \\
919 B \quad 44454 C 41 \\
91 A 1289399\end{array}$ & & $\begin{array}{l}\text { SEP } \\
\text { DB } \\
\text { DB } \\
\text { DB }\end{array}$ & $\begin{array}{l}\text { R6 } \\
\text { SP,SP,SP } \\
\text { 'DELAY?' } \\
\text { SP,ETX, } 8\end{array}$ & ¡SEND PROMPT \\
\hline $\begin{array}{l}\text { O1A4 D3 } \\
\text { O1A5 } 99 \\
\text { O1AG } 58 \\
\text { O1A7 } 18 \\
\text { O1A8 } 89 \\
\text { O1A9 } 58 \\
\text { O1AA } 18\end{array}$ & & $\begin{array}{l}\text { SEP } \\
\text { GHI } \\
\text { STR } \\
\text { INC } \\
\text { GLO } \\
\text { STR } \\
\text { INC }\end{array}$ & $\begin{array}{l}\text { R3 } \\
\text { R9 } \\
\text { R8 } \\
\text { R8 } \\
\text { R9 } \\
\text { R8 } \\
\text { R8 }\end{array}$ & $\begin{array}{l}\text {;GET INPUT } \\
\text {;STORE IN } \\
\text {;MEMORY } \\
\text {;PARAY STRING AREA }\end{array}$ \\
\hline $\begin{array}{l}\text { 91AB } 3950 \\
\text { O1AD }\end{array}$ & & $B R$ & PROMPT & $\begin{array}{l}\text {;GET NEXT } \\
\text { ¡PARAMETER SET }\end{array}$ \\
\hline & $\begin{array}{l}\text {;CHANG } \\
\text {;IN CA }\end{array}$ & & $\begin{array}{l}\text { ACH" INSTR } \\
\text { IOUS RESET. }\end{array}$ & N AT $9888-8982$ TO \\
\hline $\begin{array}{l}01 \mathrm{AD} F 800 \\
81 \mathrm{AF} \mathrm{BF} \\
81 \mathrm{BQ} \mathrm{AF} \\
01 B 1 \mathrm{IF}\end{array}$ & BUPN: & $\begin{array}{l}\text { LDI } \\
\text { PHI } \\
\text { PLO } \\
\text { INC }\end{array}$ & $\begin{array}{l}\theta \\
\mathrm{RF} \\
\mathrm{RF} \\
\mathrm{RF}\end{array}$ & $\begin{array}{l}\text {;SET UP POINTER } \\
\text {;TO LOCATION } \\
\text {;OF JMP ADDRESS }\end{array}$ \\
\hline $\begin{array}{l}81 \mathrm{~B} 2 \mathrm{~F} 898 \\
81 \mathrm{~B} 4 \mathrm{5F} \\
\text { 81B5 IF } \\
9186 \mathrm{F87B} \\
01885 \mathrm{~F}\end{array}$ & & $\begin{array}{l}\text { LDI } \\
\text { STR } \\
\text { INC } \\
\text { LDI } \\
\text { STR }\end{array}$ & $\begin{array}{l}\text { A.I(GLITCH) } \\
\text { RF } \\
\text { RF } \\
\text { A. } 8 \text { (GLITCH) } \\
\text { RF }\end{array}$ & $\begin{array}{l}\text {;GET NEW ADORESS } \\
\text {;STORE IN } 8681\end{array}$ \\
\hline
\end{tabular}

;FALL THRU TO UERIFY WHEN THRU

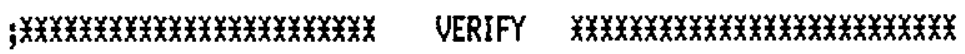

$81 \mathrm{~B} 9$

;OUTPUTS I SAMPLES, INTERUAL, AND DELAY DATA FOR USER ;INSPECTION. COMPUTES LINEAR CHECKSUM (LINEAR SLM OF MEMORY ;BYTES) ONER PROGRAM AREA FROM 8898 TO LABEL "ENDCHK" AT END OF ; "TSEC", AND OUTPUTS RESULT. PRCHPTS HITH "ACTION...?" FOR USER ;RESPONSE. ENTER UPPERCASE "G" TO BEGIN EXECUTION OF "MAIN", ANY ;OTHER CHARACTER TO START "INIT" OUER AGAIN. "PARPTR" AND ;"DATPTR' ARE RE-INITIALIZED BEFORE THE JLMP TO "MAN".

; "VERIFY" EXECUTES WITH PC=NAINPC=R8.

Q189 F898

Q $18 \mathrm{BB}$ B3

B1BC F846
VERIFY: LDI

PHI

LDI
A. I(OUTNM)

R3

A.8(GLTNIM) FNOA THAT "INDAT'
"FIRST BUSINESS IS

;TO INIT "OUTNPC"

$$
F-21
$$


ANOCET SYSTEMS 1802 CROSS-ASSEMBLER - VERSION 1.48

TREC

PROGRAY

\begin{tabular}{|c|c|c|c|c|}
\hline B1BE A3 & & PLO & R3 & ;IS FINISHED \\
\hline $\begin{array}{l}81 \mathrm{BF} F 891 \\
\text { O1C1 B8 } \\
91 \mathrm{C} 2 \mathrm{~F} 891 \\
\text { O1C4 A8 }\end{array}$ & & $\begin{array}{l}\text { LDI } \\
\text { PHI } \\
\text { LDI } \\
\text { PLO }\end{array}$ & $\begin{array}{l}\text { A.1(PARAM) } \\
\text { R8 } \\
\text { A.8(PARAM) } \\
\text { R8 }\end{array}$ & $\begin{array}{l}\text {;RESET PARPTR TO } \\
\text {;START OF } \\
\text {;PARAY STRING } \\
\text {;BEFORE UERIFYING }\end{array}$ \\
\hline $\begin{array}{l}\text { O1C5 D6 } \\
81 C 6 \text { OABABB }\end{array}$ & & $\begin{array}{l}\text { SEP } \\
\text { DB }\end{array}$ & $\begin{array}{l}\mathrm{R} 6 \\
\mathrm{LF}, \mathrm{LF}, \mathrm{\theta}\end{array}$ & $\begin{array}{l}\text {;CALL OUTCHR AND } \\
\text {;LEAVE TWO BLANK LINES }\end{array}$ \\
\hline $\begin{array}{l}\text { O1C9 D6 } \\
\text { O1CA BABDDB }\end{array}$ & ULOOP: & $\begin{array}{l}\text { SEP } \\
\text { DB }\end{array}$ & $\begin{array}{l}R 6 \\
L F, C R, 0\end{array}$ & $\begin{array}{l}\text {;ULOOP IS } \\
\text {;OUTPUT LOOP }\end{array}$ \\
\hline $\begin{array}{l}\text { O1CD F892 } \\
81 C F A B \\
10801\end{array}$ & & $\begin{array}{l}\text { LDI } \\
\text { PLO } \\
\text { SEP }\end{array}$ & $\begin{array}{l}2 \\
\text { RB } \\
\text { R1 }\end{array}$ & $\begin{array}{l}\text {;0.2 SEC DELAY } \\
\text { ¡AFTER CR, UIA } \\
\text {;CALL TO "TSEC" }\end{array}$ \\
\hline
\end{tabular}

¡OUIPUT \#SAMPLES; EXIT ULOOP IF $=8$.

\begin{tabular}{|c|c|c|c|}
\hline 810148 & LDA & $\mathrm{R} 8$ & ;GET \#SAMPLES HB \\
\hline $9102 B 9$ & PHI & $R 9$ & ;PUT IN OUT BUFFER \\
\hline 910352 & STR & 82 & ;ALSO ON STACK \\
\hline 810448 & $\angle D A$ & R8 & ;GET \#SAMPLES LB \\
\hline $8105 \mathrm{A9}$ & PLO & R9 & ¿PUT IN OUT BUFFER \\
\hline $8106 \mathrm{FI}$ & OR & & ;MERGE HB AND LB \\
\hline $8107 \mathrm{C2} 220 \mathrm{~F}$ & LBZ & LINSUM & ;EXIT ULOOP IF \\
\hline B10A D6 & SEP & R6 & ;ELSE SEND TEXT \\
\hline $810 B 23534140$ & DB & 'HSAMPLES' & \\
\hline $81 E 3302898$ & DB & $'={ }^{\prime}, S P, \theta$ & \\
\hline 91E6 D4 & SEP & R4 & _THEN SEND DATA \\
\hline
\end{tabular}

;OUTPUT SAMPLE INTERMAL

\begin{tabular}{|c|c|c|c|}
\hline $\begin{array}{l}\text { 81E7 } 48 \\
\text { O1E8 B9 } \\
\text { O1E9 } 48 \\
\text { O1EA A9 }\end{array}$ & $\begin{array}{l}\text { LDA } \\
\text { PHI } \\
\text { LDA } \\
\text { PLO }\end{array}$ & $\begin{array}{l}\mathrm{R} 8 \\
\mathrm{R} 9 \\
\mathrm{R} 8 \\
\mathrm{R} 9\end{array}$ & $\begin{array}{l}\text {;GET INTERUAL HB } \\
\text {;PUT IN BUFFER } \\
\text {;GET INTERUAL LB } \\
\text {;PUT IN BUFFER }\end{array}$ \\
\hline $\begin{array}{l}\text { Q1EB D6 } \\
\text { 81EC } 282920 \\
\text { Q1EF } 494 E 5445 \\
\text { 81F7 } 302908 \\
\text { O1FA 04 }\end{array}$ & $\begin{array}{l}\text { SEP } \\
D B \\
D B \\
D B \\
\text { SEP }\end{array}$ & $\begin{array}{l}\text { R6 } \\
\text { SP,SP,SP } \\
\text { 'INTERUAL' } \\
'=\prime, S P, 8 \\
R 4\end{array}$ & THEN SEND DATA \\
\hline
\end{tabular}

;OUTPUT TURN-ON DELAY

$\begin{array}{llll}\text { O1FB } 48 & \text { LDA } & \text { R8 } & \text {;GET HB } \\ \text { O1FC B9 } & \text { PHI } & \text { R9 } & \\ \text { O1FD } 48 & \text { LDA } & \text { R8 } & \text {;GET LB } \\ \text { O1FE A9 } & \text { PLO } & \text { R9 } & \end{array}$


AVOCET SYSTEMS 1862 CROSS-ASSE'BLER - VERSION 1.40

TREC

PROGRAM

\begin{tabular}{|c|c|c|c|}
\hline 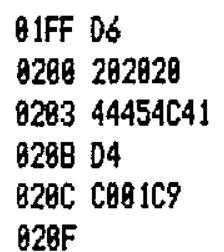 & $\begin{array}{l}\text { SEP } \\
\text { DB } \\
\text { DB } \\
\text { SEP } \\
\text { LBR }\end{array}$ & $\begin{array}{l}\text { R6 } \\
\text { SP,SP,SP } \\
\text { 'DELAY=',SP,O } \\
\text { R4 } \\
\text { VLOOP }\end{array}$ & $\begin{array}{l}\text {;THEN SEND DATA } \\
\text {;REPEAT FOR NEXT } \\
\text {;PARAMETER SET }\end{array}$ \\
\hline
\end{tabular}

ICOMPUTE CHECKSUM AND OUTPUT RESLLT.

\begin{tabular}{|c|c|c|c|}
\hline $\begin{array}{l}\text { O26F F886 } \\
8211 \quad B 7 \\
8212 A 7\end{array}$ & $\begin{array}{l}\text { LINSEM: LDI } \\
\text { PHI } \\
\text { PLO }\end{array}$ & $\begin{array}{l}8 \\
\text { R7 } \\
\text { R7 }\end{array}$ & $\begin{array}{l}\text {;FIRST SET UP } \\
\text {;POINTER TO } \\
\text {;PRCGRAY AREA }\end{array}$ \\
\hline $\begin{array}{l}821389 \\
8214 \text { E7 }\end{array}$ & $\begin{array}{l}\text { PHI } \\
\text { SEX }\end{array}$ & $\begin{array}{l}\mathrm{R} 9 \\
\mathrm{R} 7\end{array}$ & $\begin{array}{l}\text { ¡CLEAR BUFFER HB } \\
\text {;READY FOR ADDING }\end{array}$ \\
\hline $\begin{array}{l}921589 \\
9216 \mathrm{F4} \\
9217 \text { A9 } \\
821817\end{array}$ & 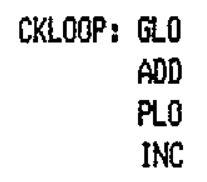 & $\begin{array}{l}\mathrm{R} 9 \\
\mathrm{R} 9 \\
\mathrm{R} 7\end{array}$ & $\begin{array}{l}\text {;GET OLD SLM } \\
\text {;ADD MEMORY BYTE } \\
\text {;SANE NEA SUM } \\
\text {;INC POINTER TO NEXT BYTE. }\end{array}$ \\
\hline $\begin{array}{l}021997 \\
821 A \text { FFBO } \\
021 C \text { CBQ215 } \\
621 F \\
621 F 87 \\
8229 \text { FFF } 6 \\
8222 \text { CBQ215 }\end{array}$ & $\begin{array}{l}\text { GHI } \\
\text { SMI } \\
\text { LENF }\end{array}$ & $\begin{array}{l}\text { R7 } \\
\text { A.1(ENDCHK) } \\
\text { CKLOOP } \\
\text { R7 } \\
\text { A. B(ENDCHK) } \\
\text { CKLOOP }\end{array}$ & $\begin{array}{l}\text {;TEST IF THRU BY } \\
\text {;COHPARING PTR } \\
\text {;AND FLAG LABEL. } \\
\text {;KEEP LOOPING IF NO } \\
\text {;BOTH BYTES } \\
\text {;HUST MATCH } \\
\text {;TO BE DONE }\end{array}$ \\
\hline $\begin{array}{l}9225 E 2 \\
822606 \\
822726282843 \\
822 F \quad 53554030 \\
023504\end{array}$ & $\begin{array}{l}\text { SEX } \\
\text { SEP } \\
\text { DB } \\
\text { DB } \\
\text { SEP }\end{array}$ & $\begin{array}{l}\text { R2 } \\
\text { R6 } \\
\text { SP,SP,SP,'CHECK' } \\
\text { 'SUK', }, S P, 8 \\
\text { R4 }\end{array}$ & $\begin{array}{l}\text {;RE-EAABLE STACK } \\
\text {;HHEN DONE, SEND }\end{array}$ \\
\hline
\end{tabular}

;OUTPUT PROMPT AND READ GQNO GO CHARACTER.

\begin{tabular}{|c|c|c|c|}
\hline $\begin{array}{l}023606 \\
823728292041 \\
0230494 F 4 E 3 F\end{array}$ & $\begin{array}{l}\text { SEP } \\
D B \\
D B\end{array}$ & $\begin{array}{l}\text { R6 } \\
\text { SP,SP,SP, 'ACT' } \\
\text { 'ION?',SP, ETX, } 1\end{array}$ & ;SEND PROAPT \\
\hline $\begin{array}{l}82443544 \\
8246 \text { CC } \\
0247 \mathrm{FF} 47 \\
8249 \text { CAB 131 } \\
\theta 24 \mathrm{C}\end{array}$ & $\begin{aligned} \text { ACLOOP: } & \text { B2 } \\
& \text { INP4 } \\
& \text { SNI } \\
& \text { LBNZ }\end{aligned}$ & $\begin{array}{l}\text { ACLOOP } \\
\text { CAPGEE } \\
\text { INIT }\end{array}$ & $\begin{array}{l}\text { ¿AMIT UART REPLY } \\
\text {;GET REPLY } \\
\text { ¡IS IT 'G' ? } \\
\text { IIF NO, "INIT" } \\
\text { 'IF YES, "MAIN" }\end{array}$ \\
\hline
\end{tabular}

¡AFTER LAST SAMPLE-SET PARAMETER HAS BEEN READ "PARPTR" POINTS TO ;START OF DATA AREA. TRANSFER IT OT "DATPTR", THE RE-INITIALIZE ;"PARPTR". THEN JUMP TO "MAIN" TO BEGIN AQUISITION PROCESS. 


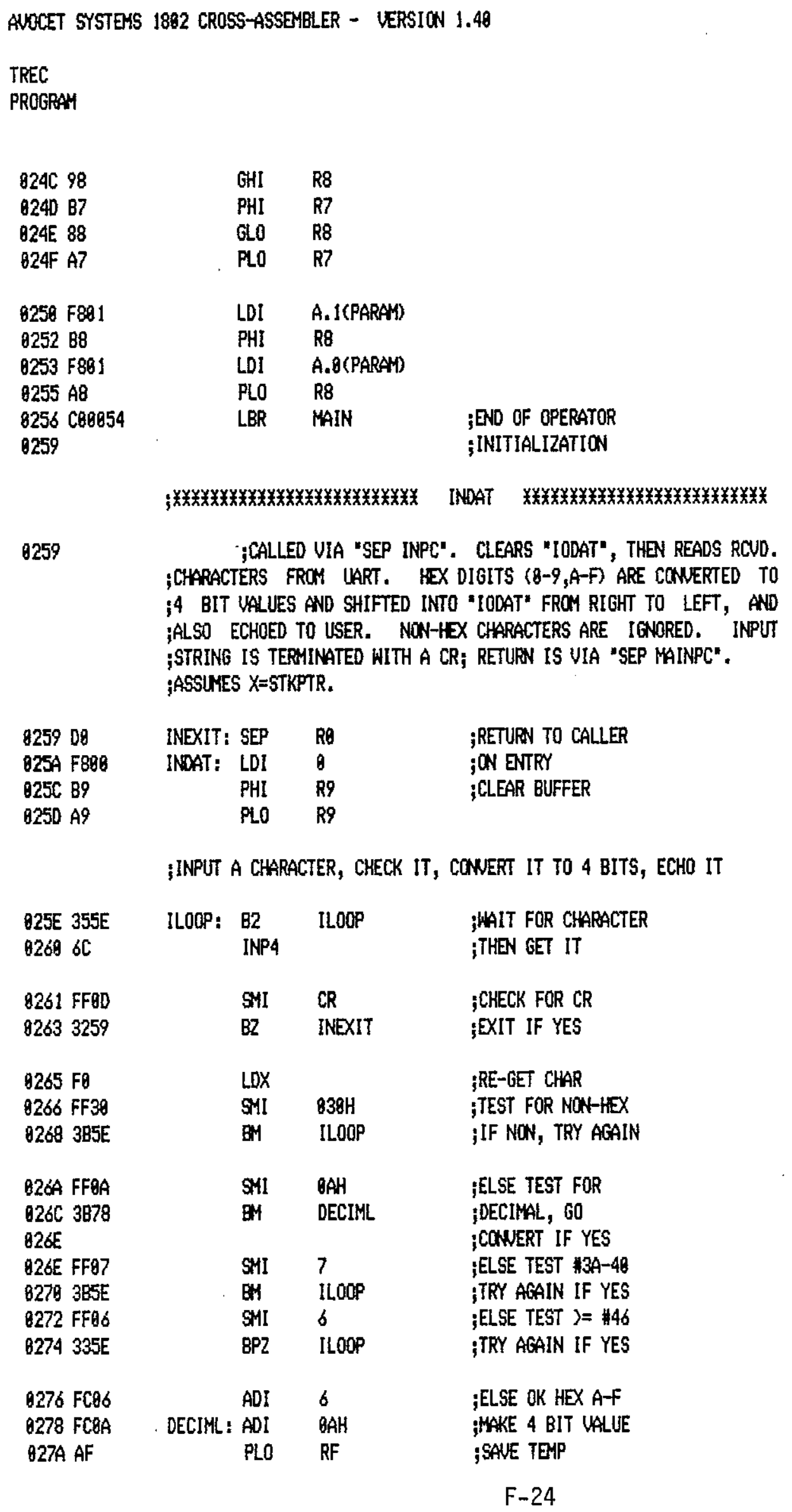


ANOCET SYSTENS 1892 CROSS-ASSEMLLER - VERSION 1.46

TREC

PROGRAM

\begin{tabular}{|c|c|c|c|}
\hline $\begin{array}{l}82783478 \\
827065 \\
\theta 27 E \quad 22\end{array}$ & $\begin{array}{ll}\text { INLOOP: } & \text { B1 } \\
& \text { OUTT5 } \\
\text { DEC }\end{array}$ & $\begin{array}{l}\text { INLOOP } \\
\text { R2 }\end{array}$ & $\begin{array}{l}\text {;HAIT FOR TRE } \\
\text {;THEN ECHO CHAR BACK } \\
\text {;UNDO AUTOINCR }\end{array}$ \\
\hline
\end{tabular}

;SHIFT RCND 4 BIT WALUE INTO "IODAT' FROM R TO L

\begin{tabular}{|c|c|c|c|}
\hline $927 \mathrm{~F} 99$ & GHI & R9 & ;GET BLFFER HB \\
\hline $9280 \mathrm{FE}$ & SHL & & \\
\hline $8281 \mathrm{FE}$ & SHL & & \\
\hline $8282 \mathrm{FE}$ & SHL & & \\
\hline $8283 \mathrm{FE}$ & SHL & & ;SHIFT L 4 \\
\hline 828452 & STR & R2 & ;PUT ON STACK \\
\hline 828589 & Q0 & R9 & ;BAFFER LB \\
\hline $8286 \mathrm{~F} 6$ & SHR & & \\
\hline $0287 \mathrm{~F} 6$ & SHR & & \\
\hline $9288 \mathrm{Fb}$ & SHR & & \\
\hline $8289 \mathrm{~F} 6$ & SHR & & ;SHIFT R 4 \\
\hline $828 \mathrm{~A} F 1$ & OR & & FHERGE HBLN+LEHN \\
\hline $828 \mathrm{~B} B 9$ & PHI & R9 & ;SAVE AS NEH HB \\
\hline $828 C 89$ & GLO & R9 & ;BUFFER LB \\
\hline $9280 \mathrm{FE}$ & SHL. & & \\
\hline Q28E FE & SHL & & \\
\hline QZ8F FE & SHL. & & \\
\hline $8290 \mathrm{FE}$ & SHL & & ;SHIFT L 4 \\
\hline 029152 & STR & R2 & ;PIT ON STACK \\
\hline $92928 F$ & GLO & $\mathrm{RF}$ & ;RE-GET NEH NIBBLE \\
\hline $8293 \mathrm{FI}$ & OR & & MERGE LBHN+NENIB \\
\hline 9294 A9 & PLO & R9 & ;SANE AS NEN LB \\
\hline $8295385 E$ & $\mathrm{BR}$ & ILOOP & ;GET NEXT DIGIT \\
\hline $8 \theta \theta \theta$ & END & & \\
\hline
\end{tabular}


AVOCET SYSTEAS 1892 CROSS-ASSEMBLER - VERSION 1.48

TREC

- SYMBOL TABLE ---

\begin{tabular}{|c|c|c|c|c|c|c|c|c|c|}
\hline & 082E & DECIML & 8278 & ILOOP & $825 E$ & NOTILT & 9081 & PLAYBK & 8808 \\
\hline & 8988 & DELOOP & 8992 & INDAT & $825 \mathrm{~A}$ & OCEXIT & 9000 & PROAPT & 8150 \\
\hline & $892 E$ & DLAY & 8974 & INEXIT & 8259 & OCLOOP & BQE2 & RESTRT & $88 A 2$ \\
\hline & 6980 & BLAYMK & 8940 & INIT & 0131 & ONEXIT & 0845 & RSLQOP & 88A5 \\
\hline ACLOOP & 8244 & DTILT & 8095 & INLOOP & $827 \mathrm{~B}$ & ONLCOP & 984E & $\mathbf{S P}$ & 8020 \\
\hline AQLOOP & 8906 & DYLOOP & 8870 & LF & $908 \mathrm{~A}$ & OTEXIT & 882E & STKTOP & 8180 \\
\hline AQUI & 98B4 & ENDCHK & 8076 & LINSWM & $829 F$ & OUTCHR & OQDE & TSEC & BOE9 \\
\hline BUPN & gIAD & ETX & 8083 & MAIN & 9854 & OUTOAT & $892 \mathrm{~F}$ & TSEXIT & 80E8 \\
\hline CAPSEE & 8847 & GDEXIT & 8804 & MDNOAT & 8814 & OUTNNA & 9046 & TSLOOP & BgEC \\
\hline CKLOOP & 0215 & GETDAT & 8905 & NOIDLE & $896 \mathrm{C}$ & PARAM & 8181 & VERIFY & $01 \mathrm{~B} 9$ \\
\hline$C R$ & 8890 & GLITCH & 8978 & NOINST & 80C4 & PBEND & 0823 & ULOOP & $B 1 C$ \\
\hline
\end{tabular}


b. PLYBK

Fi LOC COSMAC CODE Gegats betath

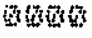

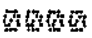

of

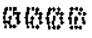

atotat

othotat

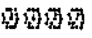

겨ㄱㅐㅡㄴ

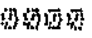

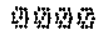

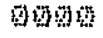

and

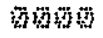

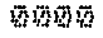

(5)

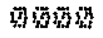

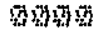

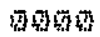

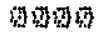

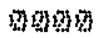

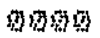

7ง

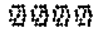

苏为可瓜

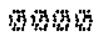

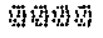

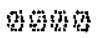

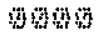

phn一ำ

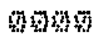

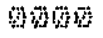

nan

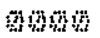

अมक्ष

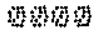

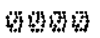

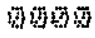

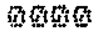

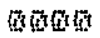

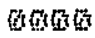

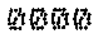

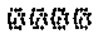

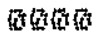

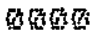

sogs

저면

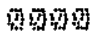

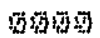

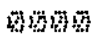

mona

모검는 는

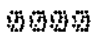

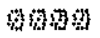

3)

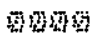

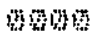

कำ

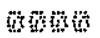

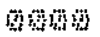

कํㅐ견

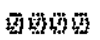

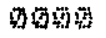

LNMO EQUFCE LINE

1 . PLAYEACH ROLTME FOA DEDF TEMF FECORTEF

E. . FOF STANDALONE UEE

3 ..IN EMEFGENCY SITUATIOHS

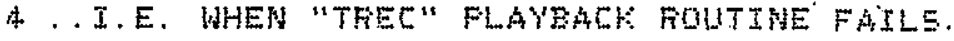

$5 \ldots$

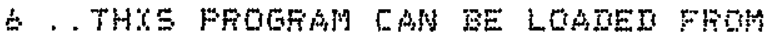

7 . THE SUFFORT COMPUTER AFTEF THETFUMEMT

8 . . FECOVEFY. IT DUMFS THE ENTIFE DATA AFEA

9. . UF MEMOR' IN THE USUAL FOPMAT ISEE "TREE"

L . PFOGRAM gPEE:

i.

t:

i.

1. . . W

i5

IS . PROGRAA COUATERS

$27 \ldots$

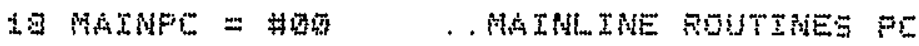

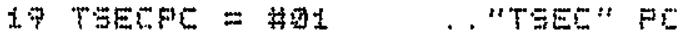

EU DUTDFE =

EI DUTTPE $=$ \#QS

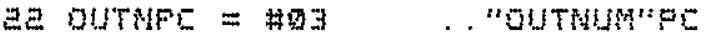

ᄅ. .

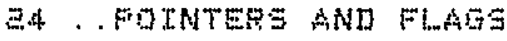

בs

DAS DATPTE = \#放

ZT GTKFTR = HDE

29 EMLFLG $=$ ThI

. DATA MEMOEY FOTHTER

- STAEK FOTATER

. ENE-OF-DATA-ABEA-FLAE

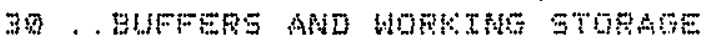

$31 \ldots$

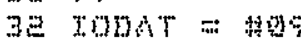

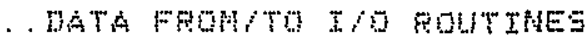

$33 \ldots$

34 . DOUNTESE

$35 \ldots$

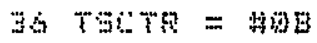

$37 \ldots$

39 . TERATEHPAD

$39 \ldots$

$45 \operatorname{Con}=40$

. SCFATEHFAR FEGTSTEF

$4 \pm$

$4 E$

4. 3

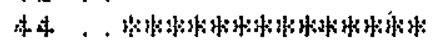

$45 \ldots$

A. IIO FOFT NAMES

47 .

4A UARTOT $=$ HDS . UART KMITTER DUFFER REGISTER

47 FOWRDN $=$ \#47 . POUER DOWA

S. .

51 . IONSTANTS

5.

$53 L F$

$5458=400$

$=$ 굴료

- LINEFEED EHARACTEF

$55 \quad 3 p$

=

CERPRABE PETUEA

. IPAEE

E.T

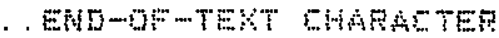

57

$53 \ldots$

57 . . Why

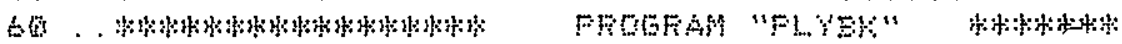

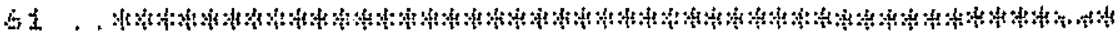

$4 \Xi \ldots$

4.

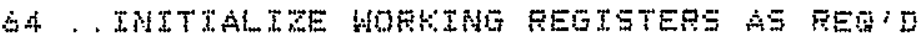




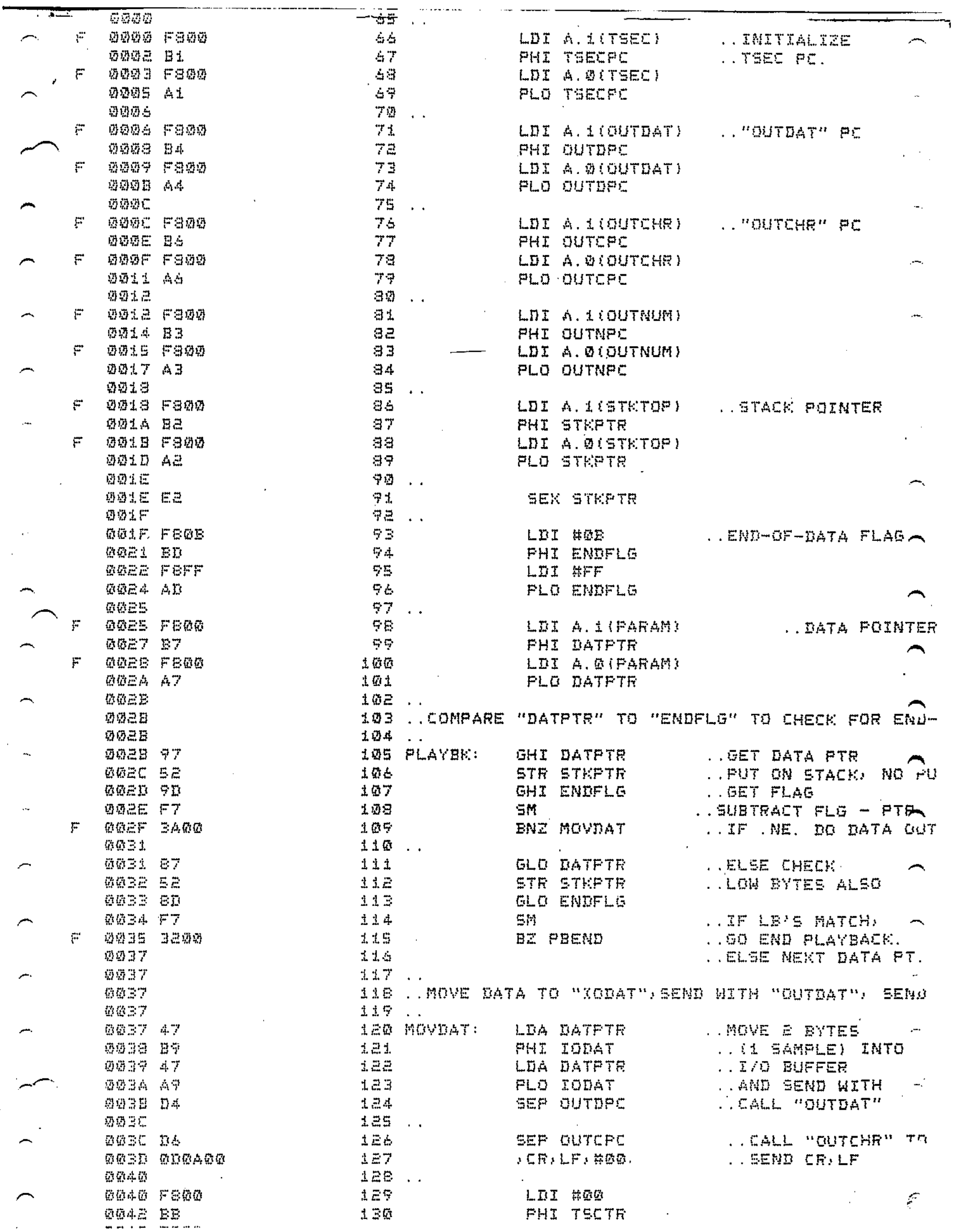




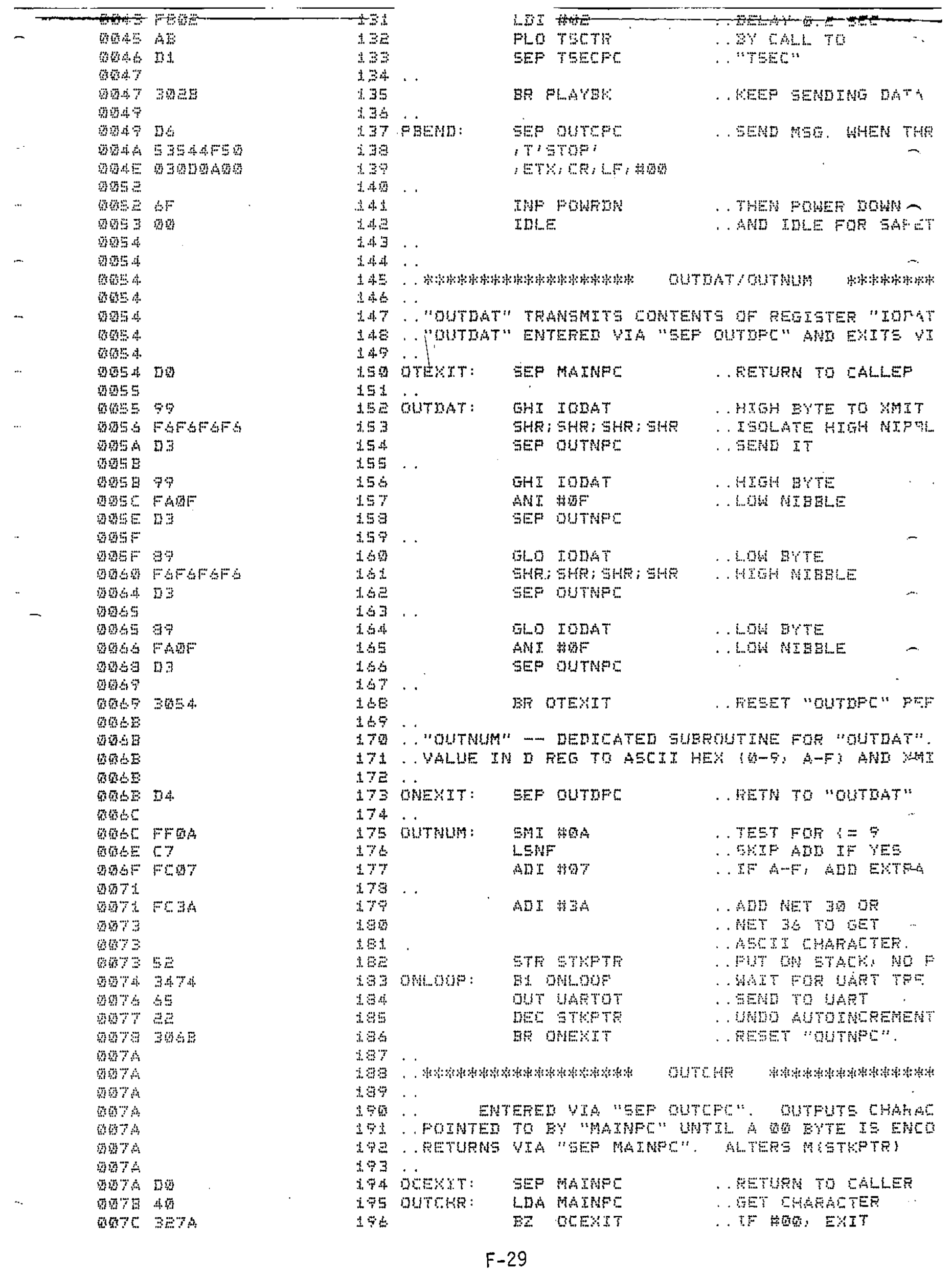




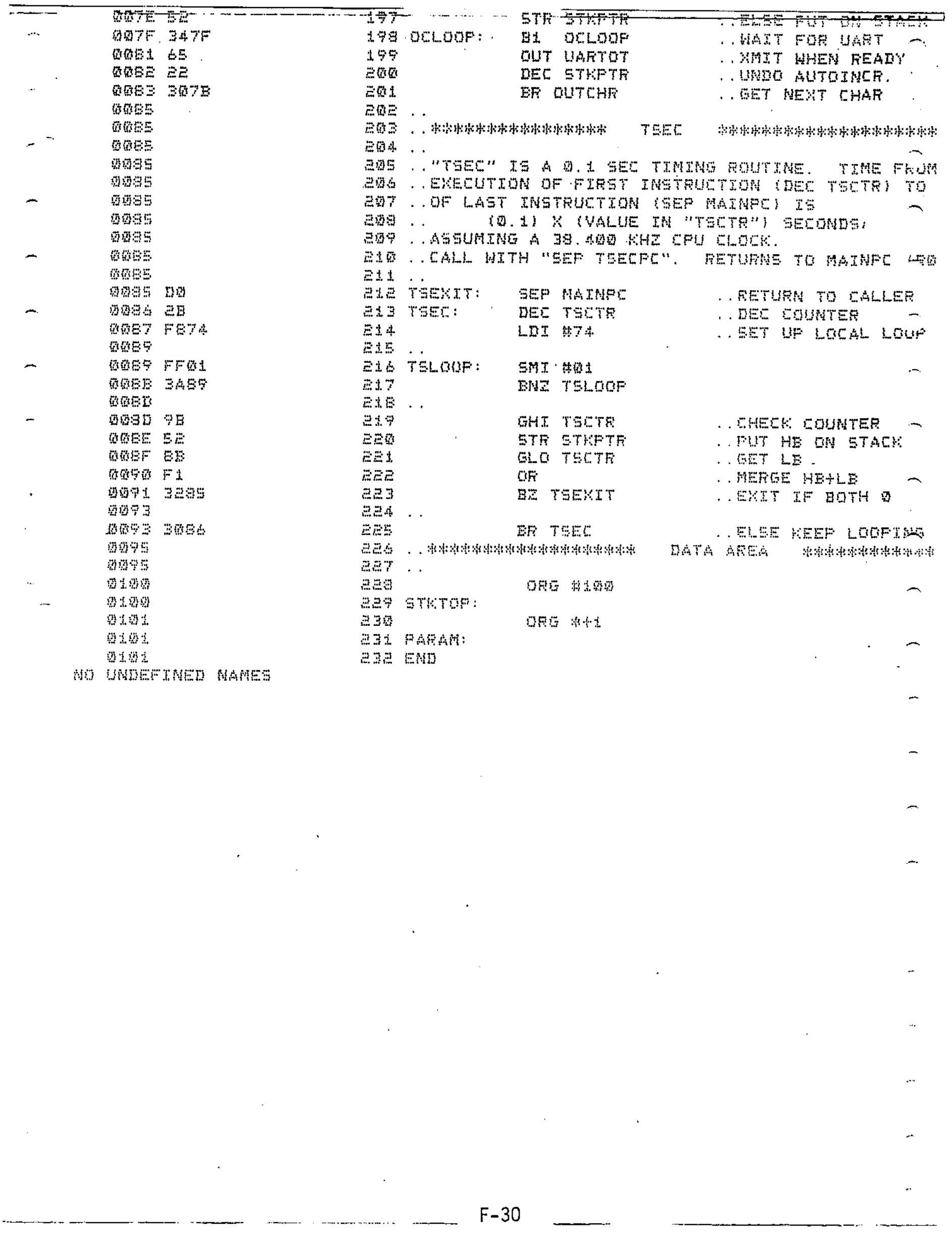


c. ADTEST

ADOFESS CODE MAEMONIC LOMMENT

INAME QF PROGRAM, ADTEST

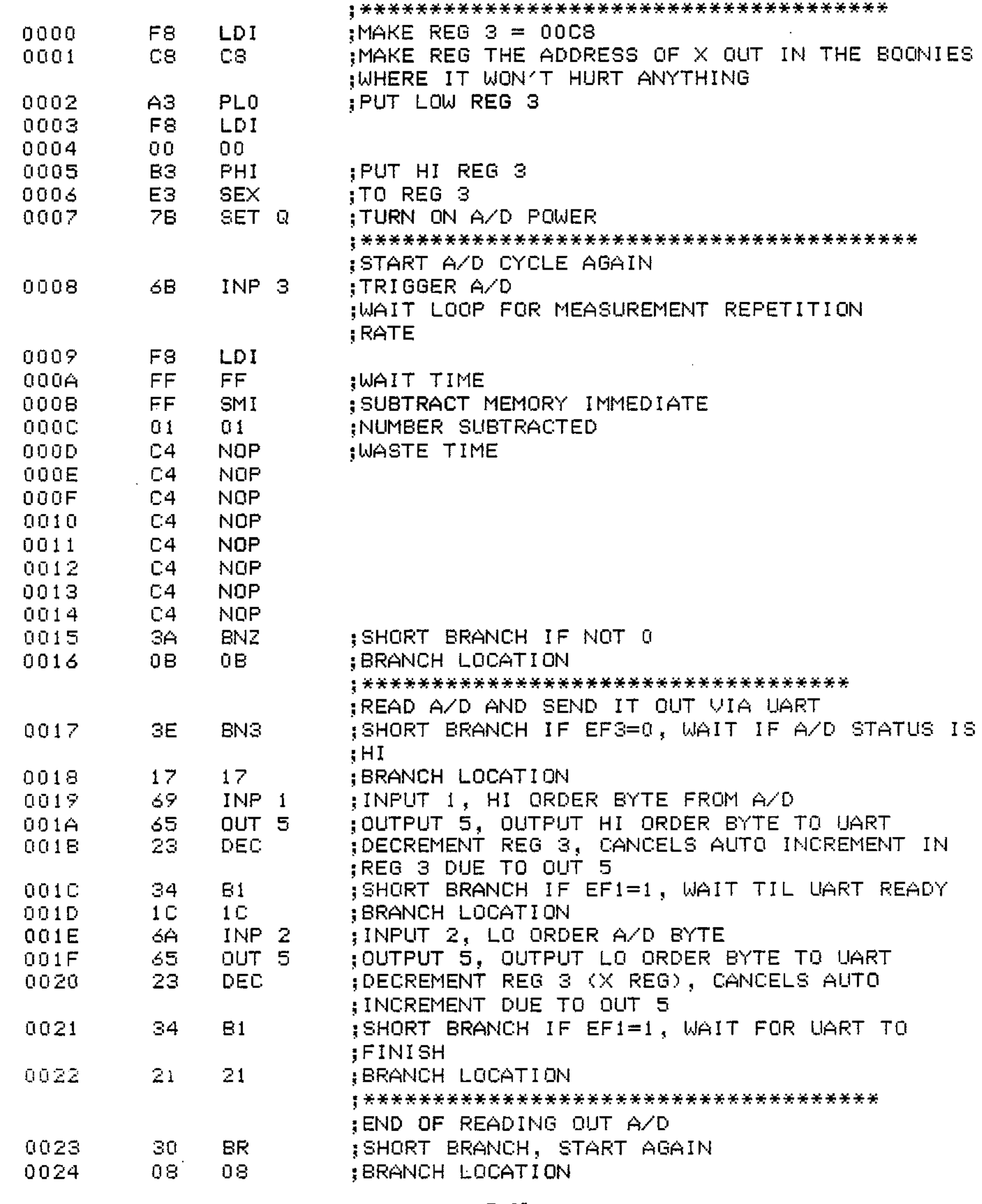


d. MEMTEST2

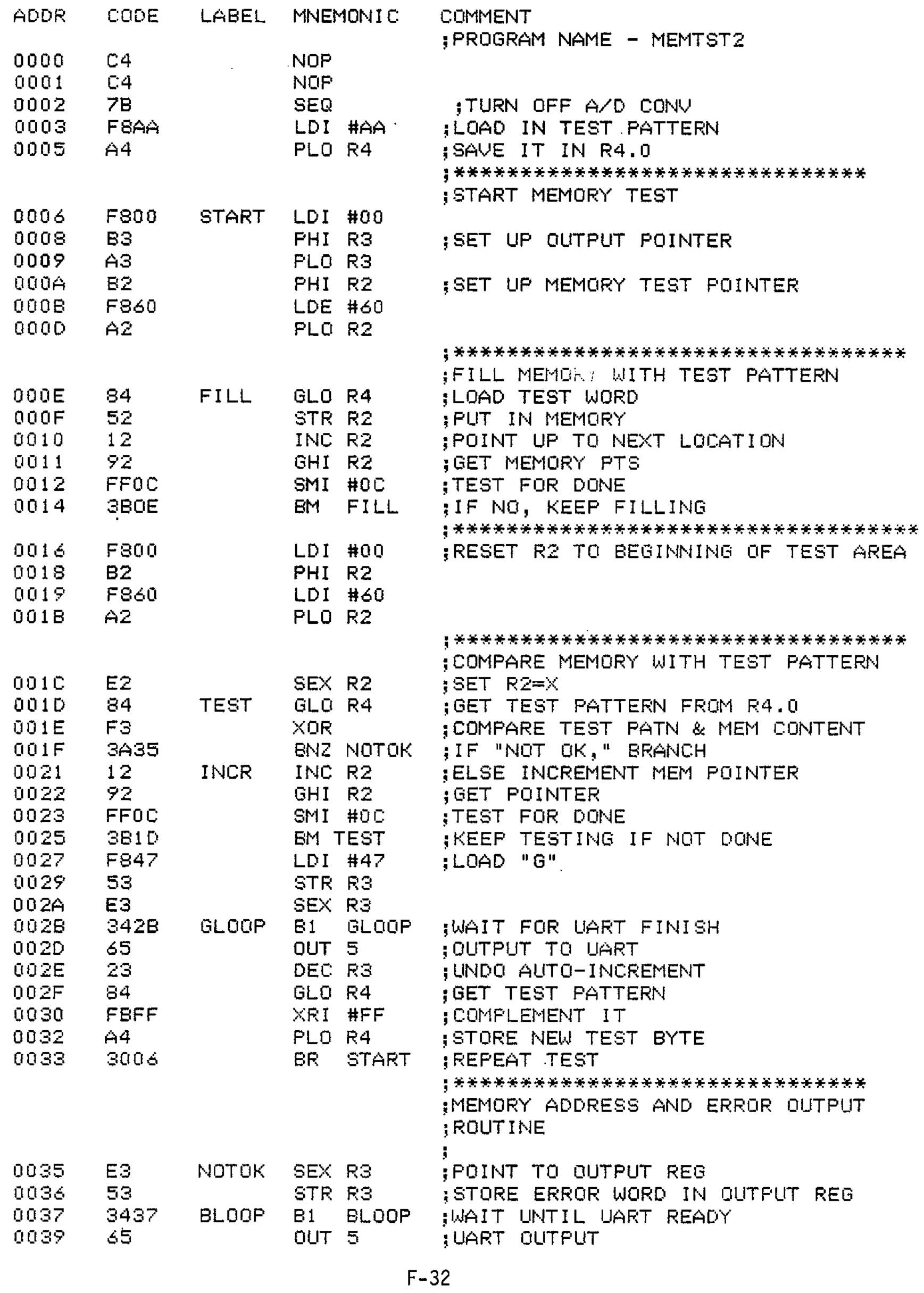




\begin{tabular}{|c|c|c|c|c|c|}
\hline $003 A$ & 23 & & DEC & R3 & 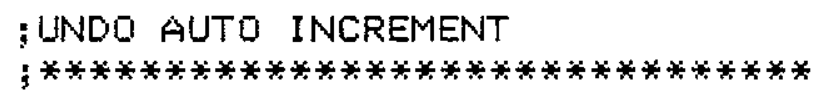 \\
\hline $\begin{array}{l}003 B \\
003 C \\
0035 \\
003 F \\
0040\end{array}$ & $\begin{array}{l}92 \\
53 \\
3430 \\
65 \\
23\end{array}$ & CLOOP & $\begin{array}{l}\text { GHI } \\
\text { STR } \\
\text { B1 } \\
\text { OUT } \\
\text { DEC }\end{array}$ & $\begin{array}{l}\text { R2 } \\
\text { R3 } \\
\text { CLODP } \\
5 \\
\text { R3 }\end{array}$ & $\begin{array}{l}\text { : UPPER BYTE OF MEM TEST LOCATION } \\
\text { OUTFUT TO UART }\end{array}$ \\
\hline & & & & & 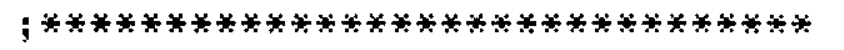 \\
\hline $\begin{array}{l}0041 \\
0042 \\
0043 \\
0045 \\
0046\end{array}$ & $\begin{array}{l}82 \\
53 \\
3443 \\
65 \\
23\end{array}$ & DLOQP & $\begin{array}{l}\text { GLO } \\
\text { STR } \\
\text { BI } \\
\text { GUTT } \\
\text { DEC }\end{array}$ & $\begin{array}{l}\text { R2 } \\
\text { R3 } \\
\text { DLOOP } \\
5 \\
\text { R3 }\end{array}$ & $\begin{array}{l}\text { :LOWER BYTE OF MEM TEST LOCATION } \\
\text { OUTPUT TO UART }\end{array}$ \\
\hline & & & & & 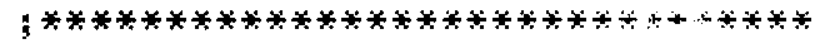 \\
\hline $\begin{array}{l}0047 \\
0049 \\
004 A \\
0040 \\
0040\end{array}$ & $\begin{array}{l}F 800 \\
53 \\
344 A \\
65 \\
23\end{array}$ & ELOOP & $\begin{array}{l}\text { LDI } \\
\text { STR } \\
\text { B1 } \\
\text { QUTT } \\
\text { DEC }\end{array}$ & $\begin{array}{l}\# 00 \\
\text { R3 } \\
\text { ELOOP } \\
5 \\
\text { R3 }\end{array}$ & $\begin{array}{l}\text { :OELIMITER CHARACTER } \\
\text {;OUTPUT TO UART }\end{array}$ \\
\hline & & & & & 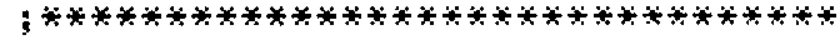 \\
\hline $\begin{array}{l}004 \mathrm{E} \\
004 \mathrm{~F} \\
0051\end{array}$ & $\begin{array}{l}\text { E2 } \\
3021 \\
C 4\end{array}$ & & $\begin{array}{l}\text { SEX } \\
\text { BR } \\
\text { NOP }\end{array}$ & $\begin{array}{l}R 2 \\
I N C\end{array}$ & $\begin{array}{l}\text { : RESET RZ=2 FOR TEST } \\
\text { RETURN TQI TEST RUUTINE }\end{array}$ \\
\hline
\end{tabular}


3. MALHINE cLDE FGR TEMFEFATURE RECGRDER ( $X \times \times$.ASC FILES)

a. TREC . ASC

. RE. .ASC PRUGRAS

$0000: C 0 \quad 01 \quad 31 \quad E 2 \quad 98 \quad B 7 \quad 88 \mathrm{~A} 7$ 0008:97 52 9D 57 3A $14 \quad 8752$ 6010:80 F7 $32 \quad 23 \quad 47 \quad B 9$ 47 A9 0018:D4 D6 00 OA 00 F8 02 AB $0020: 013008 \quad 065354 \quad 4 F 50$ 0028:03 0D OA 00 6F 00 DO 99 $0030: 555656560399 \mathrm{FA}$ OF 0038:D3 39 F6 FE FE F6 D3 89 0040:FA OF D3 30 2E D4 FF UA 0048:C7 FC 07 FC 3A 5234 4E $0050: 65 \quad 22 \quad 30 \quad 4548 \quad 8052 \quad 48$ U058:AD F1 3A EC BF AF F8 C4 $0060: 5 F$ if $5 F$ 1F $5 F \quad 97$ BD 87 0068:AD 7A $6 F$ O0 48 B9 48 A9 $0070: 48 B A$ BA AA 9A BC $8 A A C$ 0078:F8 3C AE E2 SC 52 8C F1 $0080: 32$ \&4 BE 32 A2 $6 E$ F8 40 $0088: 52 \quad 6522$ 2C F8 09 AB D1 $0090: F 8$ 49 FF 01 7A $3 A 92$ 3F 0098:9E F8 3C AE 30 7C 2E 7A 00AO:30 7C F8 4B AE OE 3274 ODAB:F8 28 AB D1 37 BI F8 $4 C$ 9080 :AE $2 E 30$ A5 $905280 F 1$ $00 B 8: 3254 \quad 7 B$ 6E 2D 99 BB 89 $0000: A B$ 2B D1 68 F8 GA FF 01 00C8:3A C6 D5 97 FF OC 38 B4 $0000: 27 \quad 273054 \quad 006957 \quad 17$ 0008:6A 57173004004032 OUEO:00 52 34 E2 652230 OE 00E8:00 2B F8 74 FF 01 3A EC $09 F 0: 985288$ F1 $32 \quad 8830 \mathrm{Eg}$ O0F8: 0100:FF FF FF FF FF FF FF FF 0108:FF FF FF FF FF FF FF FF 0110:FF FF FF FF FF FF FF FF 0118:FF FF FF FF FF FF FF FF 0420 IFF FF FF FF FF FF FF FF 0128:FF FF FF FF FF FF FF FF 0130 :FF $7 A$ F8 00 B1 F8 E9 A1 0138:F8 02 \&3 F8 $5 A$ A3 F8 00 $0140: 54$ FS $2 F$ A4 F8 00 B6 F8 0148:0E A6 F8 00 B5 F8 D5 A5 $0150: F 8$ O1 B2 F8 00 A2 F8 01 0158:B8 F8 01 A6 E2 D6 OA OD $0160: 00 \quad 7800 \mathrm{BB} F 802 \mathrm{AB} D 1$ 0168:06 $23 \quad 53 \quad 414 D \quad 504 C \quad 45$ $0170153 \quad 3 F \quad 200300 \quad 039958$ 0179:52 18 89 $5818 \mathrm{F1} 32 \mathrm{AD}$

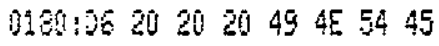
$0188: 52 \quad 56 \quad 41 \quad 4 C \quad 3 F 200300$ $010190: 0399581889581806$ 0198:20 $20 \quad 20 \quad 44 \quad 45 \quad 4 C \quad 41 \quad 59$ 01A0:3F 20030003995818 01A8:89 58 $183050 \mathrm{F8} 00 \mathrm{BF}$ O1EO:AF IF F8 00 5F AF F8 78
0158:5F F8 00 B3 F8 46 A3 F8 01C0:01 B8 F8 01 A8 O6 OA OA 01C8:00 O5 OA OD 00 F8 02 A8 01D0:01 48 \&9 52 $48 \mathrm{Ag} F 1 \mathrm{C2}$ 0108:02 of 06 2353414050 $01 E D: 4 C 45 \quad 53 \quad 302000 \quad 04 \quad 48$ 01E8:89 48 A9 D6 20 202049 01FO:4E $54 \quad 555255$ 41 4C $3 D$ 01F8:20 00 D4 $48 \quad 8948$ A9 D6 $0200: 20 \quad 20 \quad 20 \quad 44 \quad 45 \quad 4 C \quad 4159$ 0208:3D 200004 CO $01 \quad C 9 F 8$ 0210:00 B7 A7 B9 E7 89 F4 A9 $0218: 1797 \mathrm{FF} 00 \mathrm{CB} 0215 \quad 67$ 0220:FF F6 CB 0215 E2 O6 20 $0228: 20 \quad 2043 \quad 4845434853$ $0230: 5540302000040620$ 0238:20 20 41 $4354 \quad 494 F \quad 4 E$ $0240: 3 F \quad 2003003544$ 6C FF 0248:47 CA $013198 \quad B 788$ A7 0250:F8 O1 B8 F8 O1 A8 CO 00 0258:54 DO F8 00 B9 A9 35 5E 0260:5C FF OD 3259 FO FF 30 $0268: 38$ 5E FF OA $3 B 78$ FF 07 0270:3B 5E FF 0633 SE FC 06 0278:FC OA AF 3478652299 0280 :FE FE FE FE 5289 F6 F6 0288:F6 F6 F1 39 39 FE FE FE 0290:- J2 2: FI A9 30 SE FF 0298:FF FF FF FF FF FF FF ZZ 
b. AVERE *ASC

AVERG.ASC PROGRAY

$0000: C 0 \quad 01$ A2 E2 $98 \quad 8788$ A7 $0008: 9752 \quad 90 \quad 573 A \quad 148752$ $0010: 80 \quad 57 \quad 32 \quad 2347 \quad 8947$ A9 0018:D4 D6 OD OA 00 F8 02 AB $3020: 013008 \quad 065354 \quad 4 F 50$ 0028:03 0D OA OO GF 00 D0 99 $5030: F 6$ F6 F6 F6 D3 99 FA OF 0038:D3 89 F6 F6 F6 F6 D3 89 0040:FA OF D3 30 2E O4 FF OA 0048:C7 FC 07 FC 3A 5234 4E $0050: 65 \quad 2230 \quad 45 \quad 48$ BD 5248 0058:AD FI 3A GC BF AF F8 C4 10060:5F 1F 5F 1F 5F 97 BD 87 0068:AD 7A $6 F \quad 0048 \mathrm{Bg} 48 \mathrm{A9}$ $0070: 48$ BA 48 AA $9 A$ BA AC 0078:F8 3C AE E2 9C 52 8C F1 $0080: 32$ B4 SE 32 A2 $6 E$ F8 40 $0088: 526522$ 2C F8 19 AB DI $0090: 5849$ FF 01 7A $3 A 92$ 3F OC98:9E F8 3C AE $307 C$ 2E 7A $0040: 307 C \mathrm{FB}$ 4B AE $3 E 3274$ W0A8:F8 28 AB DI 37 B1 F8 AC 6080 AE $2 E$ 30 A5 $99 \mathrm{BB} 89 \mathrm{AB}$ 0088:78 7B 30 52 8D F1 3254 $0000 . F 8$ OO BA AAF8 535265 $00 C 8: 22$ D5 2B $3 \mathrm{~B} 52$ BB F1 32 U0D0:09 F8 15 FF 01 $3 A$ D3 30 $0008: B 9$ 9A FA 80 FB 8073 3A $0050: E C 2 A$ BA FB FF $B A$ SA FB 00E8:FF AA 30 F2 C4 C4 C4 C4 00FI:78 78 12 $3 A$ F6 FG F6 F1 00F8:57 17 SA F6 F6 F6 52 SA 0100 :FE FE FE FE FE F1 5717 $0108: 2097 \mathrm{FF}$ OC CB OO B4 27 $0110: 27 \mathrm{CO} 0054$ D0 F8 $08 \mathrm{AC}$ $0118: 8 C \quad 32 \quad 142 C \quad 6 B \quad 78 \quad F 8 \quad 86$ 0120 FF 01 3A 2069 FA 8032 0128:3A 6A BA F4 AA 69 FA OF $0130: 529 A 74$ EA 78787878 0138:30 18 6A FB FF FC 0152 $0140:$ BA 74 AA 69 FA OF F8 FF $0148: 52$ 9A 74 BA 30180040 $0150: 32$ 4E 523453652230 0158:4F DO 2B F8 74 FF 01 3A $016050098528 B F 1325930$ 0168: ${ }^{\circ}$ FF FF FF FF FF FF FF 0170, FF FF FF FF FF FF FF FF 0178:FF FF FF FF FF FF FF FF 0180:FF FF FF FF FF FF FF FF 0188:FF FF FF FF FF FF FF FF D39Q:FF FF FF FF FF FF FF FF 0198:FF FF FF FF FF FF FF FF 01AOAFF FF 7A F8 O1 B1 F8 5A 01A8:A1 F8 O2 B3 F8 CD A3 F8 B150:00 B4FG 2F A4FS01 86
0188:F8 $4 F$ A6 F8 $01 \quad B 5 F 8$ 15 01CO:A5 FB 01 B2 F8 71 A2 F8 01C8:01 B8 5872 A8 E2 D6 OA 0100:00 00 F8 00 BB F8 02 AB 0108:01 $06 \quad 2353 \quad 4140504 C$ 01E0:45 53 3F 200300 D3 99 01E8:58 $5218 \quad 8958 \quad 18 F 1 \quad \mathrm{C2}$ 01F0:02 2006 20 20 20 49 4E 01F8:54 45 52 56 41 4C $3 F \quad 20$ $0200: 0300039958188958$ $0208: 1806202020 \quad 44 \quad 454 C$ $0210: 4159 \quad 3 F \quad 20 \quad 0300 \quad 0399$ 0218:58 $18895818 \mathrm{CO} 01 \mathrm{CE}$ 0220:F8 00 BF AF 1F F8 00 5F 0228:1F F8 7B 5F F8 $00 \quad \mathrm{~B} 3 \quad 78$ $0230: 46$ A3 F8 01 B8 F8 72 A8 0238:D6 UA OA 0O O6 UA OD 00 $0240: F 8 \quad 02 A B \quad D 148 \quad B 95248$ 0248:A9 F1 C2 O2 $82 \quad 06 \quad 2353$ $0250: 41 \quad 4050 \quad 4 C \quad 4553 \quad 3020$ $0258: 00 \quad 04 \quad 48 \quad 8948$ A9 D6 20 $0260: 20 \quad 20 \quad 49$ 4E $54 \quad 4552 \quad 56$ 0268:41 $4 \mathrm{C} 302000 \quad 04 \quad 48 \mathrm{Bg}$ $0270: 48$ A9 062020204445 0278:4C $415930200004 \quad 00$ 0280:02 3C F8 00 B7 A7 B9 E7 0288:89 F4 A9 $1797 \mathrm{FF} \mathrm{01} \mathrm{CS}$ $0290: 028887 \mathrm{FF} 67$ CB 0288 0298:E2 O6 20 20 20 $43 \quad 4845$ $0240: 43 \quad 4 B 53 \quad 5540302000$ 0248:04 06 202020 41 43 54 $0280: 49$ 4F $4 \mathrm{E}$ 3F 20030035 02B8:B7 6C FF 47 CA 01 A2 98 02C0:B7 88 A7 F8 01 B8 F8 72 02C3:A8 CO U0 54 DO F8 00 B9 02D0:A9 35 D1 $6 C$ FF 0D 32 CC 02D8:FO FF 3038 D1 FF OA $3 B$ 02E0:EB FF 07 3B D1 FF 0633 02E8:D1 FC 06 FC OA AF 34 EE 02F0:65 22 99 FE FE FE FE 52 02F8:89 F6 F5 F6 F6 F1 8989 0300:FE FE FE FE 52 8F F1 A9 $0308: C 0$ 02 DI FF FF FF FF FF 0310:00 Z7 


$$
\text { c. FLYBK. ASC }
$$

PLYSK,ASC FROGRAM

0000:F8 00 B1 F8 86 A1 F8 00 $0008: B 4 \mathrm{FB} 55$ A4 F8 $0086 \mathrm{F8}$ $0010: 78$ A6 F8 00 B3 F8 6C A3 D018:F8 U1 B2 F8 00 A2 E2 F8 0020:0E BD FB FF AD F8 01 B7 $0028: F 8$ O1 A7 $975290 F 7$ ZA $0030: 37875280$ F7 324947 0038 :B9 47 A9 D4 D6 OD OA 00 $0040: F 800$ BB F8 D2 AB D1 30 0048:2B D6 53 54 4F 500300 0050:0A 00 6F 00 DO $99 \mathrm{FE} F$ $0058: F 6$ F6 $0399 \mathrm{FA}$ OF $D 389$ $0860: F 6$ FG FG F6 D3 89 FA OF $0068: 033054$ D4 FF OA C7 FC $0070: 07$ FC 3A 5234746522 $0078: 30$ 6B DO $40 \quad 327 A 5234$ $0080: 7 F \quad 6522 \quad 3078$ DO 28 F8 $0088: 74$ FF $013 \mathrm{~A} 39$ 9B $52 \mathrm{8B}$ $0090: F 132853086$ FF FF FF U098:FF FF FF FF FF FF FF FF $00 A 0: Z Z$

d. AOTEST . ASC

AOTEST ASSC PROGRSH

0000 :FE C8 A3 F8 $00 \quad 33$ E3 7B $0008: 68$ F8 A8 FF 01 C4 C4 C4 001U:C4 C4 CA C4 C4 3A OB 3E $0918: 17 \quad 69652334$ IC 6A 65 $0020: 23342130 \quad 08 \mathrm{ZZ}$

\section{¿. MEMTS2.ASC}

MEMTSTCA.ASC PRUGRAY

$0000: C 4$ C4 7B F8 AA A4 F800 0008:B3 A3 B2 F8 60 A2 8452 $0010: 1292 \mathrm{FF}$ OC $3 \mathrm{~B}$ OE F8 08 $0018: 82 \quad F 8 \quad 60$ A2 E2 $84 \quad 53$ 3A $0020: 351292 \mathrm{FF}$ OC $3 \mathrm{~B} 1 \mathrm{DF}$ $0028: 47 \quad 53 \quad E 3 \quad 342 B \quad 6523 \quad 84$ 0030 :FE FF A4 3006 E3 $53 \quad 34$ $0038: 37 \quad 55 \quad 23 \quad 9253 \quad 343065$ $0040: 23 \quad 8253 \quad 34 \quad 4365 \quad 23 \mathrm{Fg}$ $0048: 0053344 A \quad 6523$ E2 30 $0050: 21$ i4 Z 
AFFENOIX G. FROI-3SO PRCIGRAMS

1. FROBASIC. BAS

GET NO DOUELE

5 PROGRAM PROBASIC

10 PRINT 'FOR HEATFLCW TYFE 'RLN MENU' $\langle C R\rangle$ '

2. MENU. EAS

JET NO WOUBLE

5 PROGRAM MENU

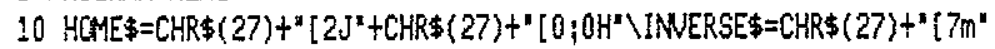

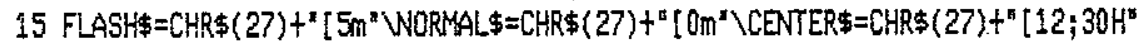

20 PRINT MGOES\ PRINT TAB(38); INWERSE\$;"MENU" ;NORMLL\$ PRINT \ PRINT

30 PRINT "1. THERMAL CONDUCTIUITY OPERATIONS"

40 PRINT "2, DON HOLE INSTRLMENT OPEEATICNS"

99 PRINT ${ }^{\circ 9}$. EXIT BASIC'

100 PRINT \PRINT FLASH" ; INPUT YOUR SELECTION " "NORMAL\$; INPUT A

110 IF A\$ $\langle " 1 "$ OR A\$>"g' THEN GOTO 20 ELSE A=VAL(A\$)

120 CN A $60 T 0140,150,20,20,20,20,20,20,220$

130 GOTO 20

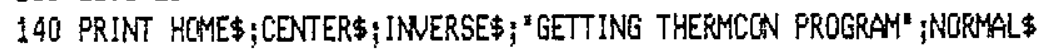

145 CHAIN "THERMCON. BAS"

350 PRINT HOME\$;CENTER\$;INUERSE\$; 'GETTING LOAOER PROGRAM" 'NORMAL

155 CHAIN "LQAOER. BAS"

$2205 \mathrm{ND}$ 
3. LGADER. BAS

SET NO DQUBLE

5 PROGRAM LQADER

19 REM DSDP INSTRLMENT PROGRAN MODIFIED FOR PRO-350

11 REM BY GEORGE L. PELLETIER WHOI 19 DEC 85

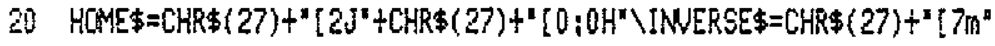

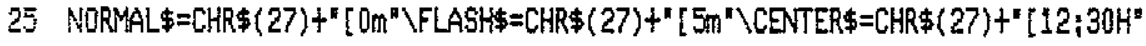

30 PRINT HOAE \$+INERSE\$+" CORING TOOL TEMPERATURE RECOROER *"+NORMAL $\$ PRINT

35 PRINT "MENU" PRINT "1. LOAD PROGRAM" PRINT "2. LOAD PARAMETERS"

40 PRINT '3, DLMP DATA' PRINT '4, DISPLAY FILE CATA"

45 PRINT '5, PRINT FILE DATA"

50 PRINT '6. CONERT \& PRINT FILE DATA" PRINT '7, END"

100 PRINT FLASH ; "ENTER YOLR CHOICE ";NORMAL\$\$ INPUT A\$\A=VAL(A\$)

110 ON A GETO $120,1000,2000,3000,4000,5000,6000$

115 GOTO 30

120 PRINT HOME +INUERSE\$+"kk LOAD PROGRAM kk'+NORMAL \$ PRINT

125 PRINT "1, LOAD MEMORY TEST" $\backslash$ PRINT "2. LQAD MAIN PROGRAM"

130 PRINT "3. LOAD A/D TEST" PRINT "4, LLAD ANERAGING PROGRAM"

135 PRINT "5. LOAD PLAYBACK PROGRAY"

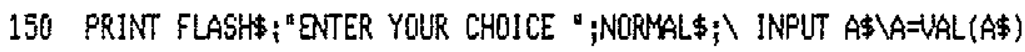

155 IF A $A 1$ OR A>S THEN 30

160 IF A $A=" 1$ " THEN PG\$ $=$ "MEMTS2.ASC" $\backslash$ GOTO 250

170 IF $A=" 2 "$ THEN PG $="$ TREC2.ASC" $\backslash$ GOT0 250

180 IF $A \$==3^{\prime \prime}$ THEN PG $\$=" A D T E S T$.ASC" $\backslash$ GOTO 250

190 IF A\$=" 4" THEN PG $\$=* A V E R G$.ASC" $\backslash$ GOTD 250

2010 IF A $=" 5^{\prime \prime}$ THEN PG\$="PLYBK.ASC" $\backslash$ GOTO 250

250 OPEN PG FOR INPUT AS FILE *1\% REM GET READY TO LOAD PROGRAM

255

256

260 PRINT HOME\$+CENTER\$+INUERSE\$+"LQADING '+PG\$+NORMAL\$

270 GOSLIB $10000 \backslash$ GOTO 30

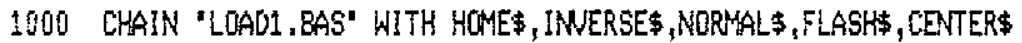

2000 CHAIN "LOAD2. BAS" WITH HOME\$, INUERSE\$, NORMAL \$,FLASH

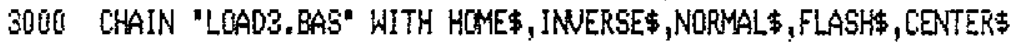

4000 CHAIN "LQAD3A. BAS" WITH HOME\$, INNERSE\$, NORMAL \$, FLASH\$, CENTER

5000 CHAIN "LOAD4, BAS" WITH HCME\$, INERSEE, NORMAL\$,FLASH , GENTER

6000 PRINT HOME\$;CENTER;; INUERSE\$; "RETURNING TO MENU" ;NORMAL"

GOOS CHAIN "MENU, EAS"

6010 END

10000 REM LOAD PROGRAA INTO DCAN HOLE INSTRLMEN SBR.

10100 INPUT $\$ 1 \%, A \$$

10150 OPEN 'XK:' AS FILE \#2A REM COUHLNICATIUAS PORT

10200 FOR $N=6$ TO LEN(A\$) STEP 3

10300 UAR $\$ M I O \$(A \$, N, 2)$ IF WARS="ZZ" THEN CLOSE $\$ 1$ A GOTO 11500

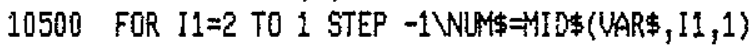

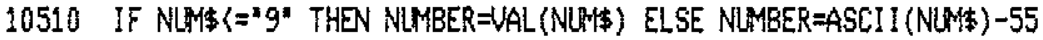

10515 IF $11=2$ THEN TOTAL=NUMBER ELSE IF $! 1=1$ THEN TOTAL=TOTAL+(NGMBER $* 16$ )

10550 NEXT 11

10600 PRINT $* 2 \%$,CHR $\$$ (TOTAL);

11460 NEXT $N$

11470 G0TO 10100

11500 CLUSE $\$ 1 \%, 72 \%$

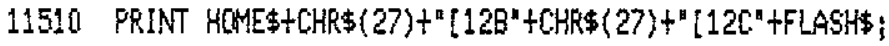

11520 PRINT "PRGGRAM TRANSMITTED" HNORMAL\$ PRINT

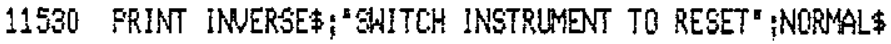

11550 PRINT "PRESS RETURN TO CONTINUE " $\backslash$ INPUT A

11600 RETURN 


$$
\text { 4. LOAD 1. BAS }
$$

SET NO JOLELE

1060 PRGGRAY LOAD1(HOHE\$, INERSE\$,NORMAL F,FLASH , CENTER $\$$ )

1081 RES 19 DEC 85

1005 PRINT HOME\$+INUERSE\$+"kk LOAD PARAMETERS k* +NURMAL\$

1010 OPEN "XK:" AS FILE \#2A REM COAUNICATIONS PORT

1015 PRINT \ PRINT INERSE $\$ 十^{3}$ MOVE INTERFACE SHITCH FROM RESET TO RIN" ${ }^{\mathrm{B}}$;NORMAL\$

1017 LINPUT $* 2 \%, A$

$1018 \mathrm{~N} 2=0$

$1019 \mathrm{~B} \$=1 "$

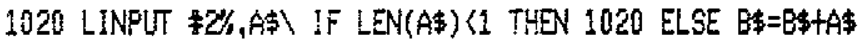

1025 IF ASCII(MIO\$(A $\$$,LEN(A\$),1))=3 THEN GOSUB 1200 GOTO 1027 ELSE 1020

1027 FRINT $8 \$ ;$ " (DECIMAL) " W2=N241 IF N2=4 THEN N2=1

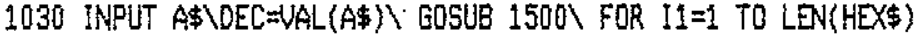

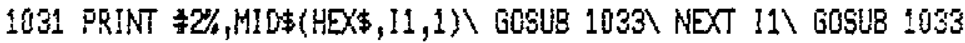

1032 PRINT *2\%, CHR (13) \GOTD 1040

1033 FOR 12=1 TO 5O NEXT 12 RETURN

1040 IF HEX $\$=0000^{\circ}$ AND N2=1 THEN 1045 ELSE 1019

$1045 \mathrm{~N}=1$

$1049 B \$=1 n$

1050 LINPIT $\$ Z Z, A \$ \backslash$ IF LEN(A\$) 11 THEN 1050 ELSE B $=8 \$+A \$$

1060 IF ASCII (MID\$(A\$, LEN(A $(A), 1))=13$ THEN $C \$(N)=B \$ N=N+1 \backslash B \$=4$

1070 IF ASCII(MID $\$(A \$, L E N(A \$), 1))=3$ THEN CS(N)=8\$\GOTO 1090

1080 GOTO 1050

1090 FQR $N 1=2$ TO $\mathrm{N}-1$

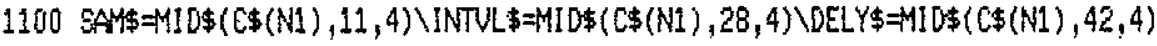

1110 HEX $=S A 4 \pm$ EOSUB 1600 PRINT MIO\$(C\$(N1),1,10)+DEC\$;

1120 HEX $\$=$ INTUL $\$$ GOSLB 1 G00 PRINT MID $(C \$(N 1), 15,13)+D E C \$ ;$

$1130 H E X \$=D E L Y \$ \backslash$ GOSUB 1600 PRINT MID $\$(C \$(N 1), 32,10)+D E C \$$

1140 NEXT NI\ PRINT C\$(N)

3150 CALL INKEY (A\$) IF LEN(A\$)=0 THEN 1150

1160 IF ASCII(A\$)=13 THEN PRINT \$U, CHRS(13) GOTO 1017

$1: 70$ IF $A \$=" G *$ THEN PRINT $* 2 \%, " G$ '

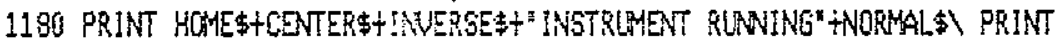

1190 PRINT "PRESS RETURN FOR MENU" $\backslash \backslash$ INPUT A

1195 CHAIN "LQADER. BAS"

1200 REY 8 CLEANUP

1210 IF LEN(B\$)>11 THEN B $=$ =IIL $(B \$, L E N(E \$)-10,11)$

1200 RETURN

1500 REM DEC TO HEX CONWERT

$1505 \mathrm{HEX} \$=\div$

1510 FUR $N=12$ TO 4 STEP -4

$1515 \mathrm{HEX}=0$

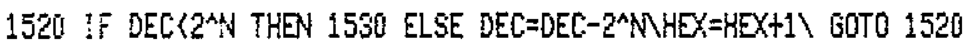

1530 IF HEX 10 THEN HEX $=H E X+C H R$ (HEX+48)

1540 If HEX>9 THEN HEX $=$ HEX $\$+C H R 5$ (HEX+55)

$1550 \mathrm{NEXT} N$

1560. IF DEC 110 THEN HEX $=H E X \$+C H R \$$ (DEC+48)

1570 IF DEC)9 THEN HEX $\$=H E X \$ C C H R \$(D E C+55)$

1580 RETURN

1600 REM HEX TO DEC COARERT

1610 FOR $I 1=4$ TO 1 STEP -1 W $=$ =NIO 0 (HEX $0,11,1)$

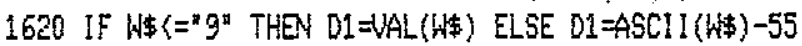

1630 IF $11=4$ THEN $[N=11$

1640 IF $11=3$ THEN $D N=C N+(O 1 * 16)$

1650 If $11=2$ THEN $D N=0 N+(01 \times 256)$

1660 IF $11=1$ THEN $D N=0 N+(01 * 4096)$

1670 NEXT II $\backslash D E C \$=N I N$ (ON)

1680 RETURN 
5. LDAD2.BAS

SET HO DOUBLE

2000 FRUGRAM LOAD2(HOME\$, INERSE\$,NORMAL \$,FLASH

2001 REM 19 DEC 85

2005 CENTER1 $\$=C H R \$(27)+113 ; 35 H^{n}$

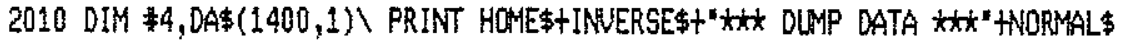

2015 OPEN "INTERIM" AS FILE $\$ 4$, UIRTLLLL

2016 PRINT CENTER \$ INUERSE ; "CLEARING INTERIM STORAGE" ;NORMAL.\$

2018 FOR $N 1=0$ TO 1400\OA $(N 1,0)=$ " $\backslash D A \$(N 1,1)=" \backslash N E X T$ N1

2020 OPEN "XK:" AS FILE *2A REM COMMLNICATIONS PORT

2030 PRINT \FRINT IMUERSES!" WITCH INSTRLANENT CONTROL TO RESET THEN PRESS ";

2040 PRINT "RETURN";NORMAL\$ INPUT A\$

2050 LINPUT $\$ 2, A \$ \backslash$ IF LEN(A\$)>0 THEN 2050 REM CLEAR CON PORT

2055 IF LEN(A\$) $>0$ THEN 2050

2060 PRINT \ FRINT "SWITCH INSTRLMENT CONTROL TO "FLLASH ; RLN" ;NORMAL\$;" NOW"

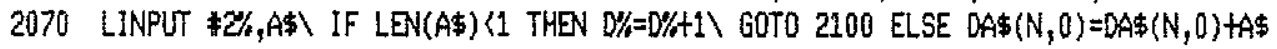

2080 if N=0 THEN PRINT HCHE ; CENTER \$FLASH ; 'DIMPING DATA' ;NORMAL\$

2090 IF LEN(DA\$ $(N, 0))<6$ THEN 2070 ELSE N=N+1\ PRINT CENTERI $; M O \%=0 \backslash 60702070$

2100 IF $0 \%<800$ THEN 2070

2110 CLOSE $\$ 2 \%$

2120 PRINT HOME\$+CENTER +INUERSE\$+"FORMATTING DATA"+NGRMAL GUSUB 2290

2130 CLOSE $¥ 2 \%$

2140 FRINT HOME\$

2150 FOR N1=0 TOM PRINT DA\$(N1,1), \NEXT NI $\backslash$ PRINT

2160 PRINT FLASH\$"DUMP TO DISK? (N OR RETURN)" +NORMAL \$ $\backslash$ INPUT A

2170 IF A $={ }^{\prime} \mathrm{N}^{2}$ THEN 2280

2180 PRINT "FILENAME " $\backslash$ INPUT NA

2190 PRINT ROME\$+CENTERA+INUERSE\$+"WRITING ",NA\$+NORMAL\$

2200 OPEN NA\$ FOR OUTPUT AS FILE $\div 3 \%$

2210 PRINT $\$ 3 \%, N$

2220 FOR N1=0 TO N

2230 PRINT $\$ 3 \%$, OA $\$\left(\mathrm{~N}_{1}, 1\right)$

2240 NEXT N1

2260 CLOSE $73 \%$

2260 PRINT HOME\$+CENTER \$FLASH + "FILE "NA\$;" STORED"+NORHAL\$ PRINT

2270 PRINT "PRESS RETURN FOR MENU"; $\backslash$ INPUT A\$

2275 CLOSE

2280 CHAIN "LOADER. EAS"

2290 REM RECONFIGURE DATA FROM C $\$$ TO DA\$

$22950 \%=$ " $W 33=0$

2300 FOR N1=0 TO N-1

2320 FOR NZ=1 TO LEN $(D A \$(N 1,0)) \backslash A \$=M I D \$(D A \$(N 1,0), N 2,1)$

2330 IF ASCII(A\$)) 47 ANO ASCII(A\$)<90 THEN D\$=D\$十本

2335 IF LEN $(D \$)=4$ THEN DA $\$(N 3,1)=0 \$ W 3=N 3+1 \backslash D="$ " $\backslash$ PRINT CENTERI $\$$; 3

2340 NEXT N2\NEXT N1

$2350 N=N 3-1 \backslash$ RETURN 
6. LQADS. BAS

SET NO DOLLLE

TOOO PRUGKAY LUAD3(HOWE\$, INERSE\$,NORMAL \$,FLASH , CENTER\$)

3001 REM 19 DEC 85

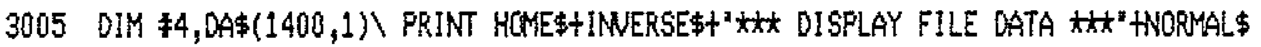

3006 OPEN "INTERIM" AS FILE *4, UIRTLAAL

3007 FRINT CENTER | INRERSE\$;"CLEARING INTERIM STORAGE" NORMAL\$

3008 FOR $N=0$ TO 1400\DA $\$(N, 0)=$ "WEXT $N$

3010 GUSUE 3000

3020 FOR NI=0 TO M PRINT USING ' 'LLL ',N1, DA\$ $(N 1,0)$;

3030 IF N1-INT $(\mathrm{N} 1 / 84) * 84=83$ THEN 3035 ELSE 3040

3035 PRINT \PRINT "PRESS RETURN TO CCATINUE"; \INPUT A\$ PRINT HOME\$

3040 NEXT NI\ PRINT \PRINT "DISPLAY DATA AGAIN? (Y OR RETURN)"; INPUT A\$

3045 IF A\$="Y" THEN PRINT HOME\$ GOTO 3020

3048 CLOSE

3050 CHAIN "LOADER,BAS"

9000 PRINT \PRINT "FILENAME "; INPIS NAT

9005 PRINT HCHE\$+CENTER\$+INUERSE\$+"READING "NA\$+NORMAL\$

9010 OPEN NA FOR INPUT AS FILE \#2\%

3030 INPUT $\$ 2 \%, M$ REM NLMBER OF RECORDS IN FILE

$9040 \mathrm{FOR} N 1=0$ TO N

9050 INPUT $¥ \%, \mathrm{DA} \$(\mathrm{~N} 1,0)$

3060 NEXT NI

9070 CLOSE $\$ 2 \%$

9075 PRINT HOMES

3080 RETURN 


\section{LDADBA, BAS}

SET NO DOUELE

40OO PROGRAM LOADZACHOHE\$, INERSE $\$$, NORMAL

4001 REM 19 DEC 85

4002 DIM $\div 4$, OAA $\$(1400,1)$

4003 OPEN "INTERIM" AS FILE $\$ 4$, VIRTUAL

4005 PRINT HCWES+INERSE $++^{*}$ *

4006 PRINT CENTER ; INERSE ; 'CLEARING INTERIM STORAGE' ;NORMAL

4007 FOR $N=0$ TO $1400 \backslash D A \$(N, 0)={ }^{-} \backslash N E X T N$

4010 G0SUB 9000

4015 PRINT HOME\$;CENTER\$;INUERE\$;"PRINTING "NA\$; ;ORMAL\$

4020 OPEN "LP:" FOR OUTPUT AS FILE ‡20 REM SET LINE PRINTER OUTPUT

4035 PRINT. $\$ 2 \%, N A \$$ PRINT $\$ 2 \%$

4040 FOR N1 $=0$ TO N STEP 6

4050 FOR $N 2=0$ TO 5

4055 PRINT $\approx 2 Z$ USING 'LLLL ",INT(N1+N2), CA\$(N1+N2,0);

4060 NEXT N2 PRINT \#2A NEXT N1

4070 CLOSE

4080 CHAIN "LOADER. BAS"

3000 PRINT \ PRINT "FILENAME "; INPUT NA\$

9005 PRINT HOME\$+CENTER\$+INUERSE\$+"READING "NNA\$+NORMAL\$

9010 OPEN NAF FOR INPUT AS FILE $¥ 2 \%$

9030 INPUT ₹2\%,M REM NUMBER OF RECOROS IN FILE

9040 FOR N1=0 TON

3050 INPUT $\# 2 \%, D A \$(N 1,0)$

9060 NEXT N1

9070 CLOSE $\$ 2 \%$

9075 FRINT HOHE\$

9080 RETURN 
8. LOAD4 . EAS

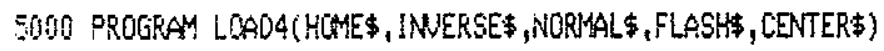

5001 REM 19 DEC 85

S002 DECLARE DOUBLE $A, B, R 1, R 2, A L, B E, G A, T M, L R \backslash D I M \neq 4, D A \neq(1400,1)$

5003 OPEN "INTERIM" AS FILE $\$ 4$, VIRTUAL

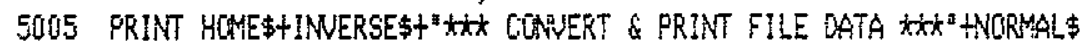

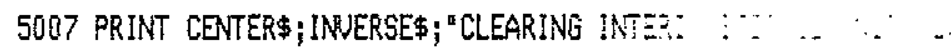

5008 FOR $N=0$ TO 1400\DA\$ $(N, 0)="$ " NEXT $N$

5010 PRINT "INSTRLMENT NLRABER? " $\backslash$ INPUT A\$I $=V A L(A \$)$

5015 RESTOKE

5020 FOR $N=0$ TO $\triangle$ READ A, B,R1,AL, BE, GA N NEXT N

5030 PRINT "CRUISE NLMBER?" $\backslash$ INPUT CRD PRIN "DATE? " $\backslash$ INPUT DA

5040 G0SLB $9000 \mathrm{~W} 2=\mathrm{N}$

5045 OPEN NA ${ }^{2}+^{2}$.TXT" FOR DUTPUT AS FILE *1\%

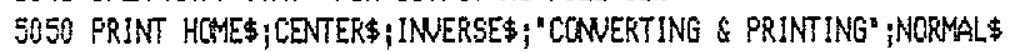

5060 DATA $\quad .14797245, .55253495,8715,8.9910055 E-4,2.4362808 E-4,1.2626278 E-7$

5062 DATA $.14797245, .55253495,8715,8.9910055 \mathrm{E}-4,2.4362808 \mathrm{E}-4,1.2626278 \mathrm{E}-7$

5064 DATA $.14797245, .55253495,8715,8.9910055 \mathrm{E}-4,2.4362808 \mathrm{E}-4,1.2626278 \mathrm{E}-7$

5066 DATA $.14797245, .55253495,8715,8.9910055 \mathrm{E}-4,2.4362808 \mathrm{E}-4,1.2626278 \mathrm{E}-7$

5068 DATA $.14797245, .55253495,8715,8.9910055 E-4,2,4362808 E-4,1.2626278 E-7$

5070 DATA .14797245,.55253495,8715,8.74722104E-4,2.47238861E-4,1.16103772E-7

5072 DATA $.14797245, .55253495,8715,8.84648075 \mathrm{E}-4,2.45607753 E-4,1.21657042 \mathrm{E}-7$

5074 DATA .14797245, $.55253495,8715,8.78525336 \mathrm{E}-4,2.46894380 \mathrm{E}-4,1.17247016 \mathrm{E}-7$

5076 DATA .14797245,.55253495,8715,8.83512916E-4,2,45027504E-4,1.17903032E-7

5078 DATA .14797245, $55253495,8715,8.50827418 E-4,2.50936456 E-4,1.03111000 E-7$

5080 DATA .14797245, .55253495,8715,8.78246674E-4,2.46585729E-4,1.17843303E-7

5100 OPEN 'LP:' FOR OUTPUT AS FILE FEA REM SET LIP LINE PRINTER

5105 L $=0 \backslash$ REM LINE COLNTER

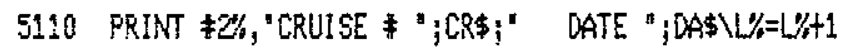

5115 PRINT $\# 1 \%, "$ CRUISE * "CR ;" DATE ";DA

5120 PRINT $₹ 2 \%$, "INSTRUMENT \# "; ILL\%=L\%+1

5125 PRINT $\$ 1 \%, "$ INSTRLAENT * "iI

5130 REM PRINT CHR (27); CHR (58);

5140 PRINT $\# 2 \%, N A \$$

5145 PRINT $\$ 1 \%, N A \$+^{*}$, DAT"

5150 PRINT *2A PRINT $* 2 \%$, REC COLNT RESISTANCE TEMP" $\backslash \mathrm{L} \%=\mathrm{L} \%+3$

5155 PRINT \#1\% PRINT \#1\%," REC COLNT RESISTANCE TEMP"

5160 FOR $I=0$ TO N2

5170 FOR $11=4$ TO 1 STEP $-1 \backslash C \$=M 1 D \$(D A \$(1,0),[1,1)$

5180 IF I1=1 THEN IF $\left((C \$\rangle^{\prime \prime} 3^{n}\right)$ AND $\left(C \$\left\langle^{\circ} 8^{\prime \prime}\right)\right)$ OR $\left.(C \$\rangle^{\prime} B^{n}\right)$ THEN DN=9999

5130 IF $11=1$ ThEN 5260

5200 IF $C \$\left(=" 9^{n}\right.$ THEN $01=\forall A L(C \$) \backslash$ GOTO 5220

5210 DI $=A S C 11(C+)-55$

5220 IF $11=4$ THEN $D N=01$

5230 IF $I 1=3$ THEN $[N=[\mathrm{N}+(01 * 16)$

5240 IF I1 $=2$ THEN ON $=0 \mathrm{~N}+(01 \times 256)$

5250 G0T0 5270

5260 IF $C \$\left\langle{ }^{\prime \prime} 8^{n}\right.$ THEN $D N=-D N$

5270 NEXT 11

5280 PRINT FU USING "I;

5285 PRINT \#1\% USING "

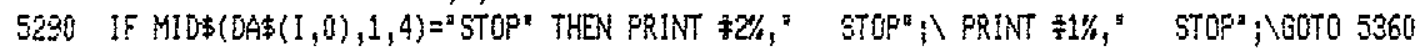

5300 IF DN=9999 THEN PRINT $\$ 2 \%$ " ONER" ; PRINT \$1\%," ONER" $\backslash$,GOTO 5360

5310 FRINT $\$ 2 \%$ LISING "

$5320 R 2=81 *(1 /(1 /(((A)$ ON)/2048)+B)-1)) PRINT $\ddagger 2 \%$ USING

$5330 L R=L 06(R 2) \backslash M=\left(1 /\left(A L+L R \times B E+L R^{\wedge} 3 \times[S A)-273.15\right)\right.$

5340 PRINT \#Z USING" 
5345 IF $L \%=60$ THEN L $\%=0 \backslash$ PRINT $\neq Z 2$, CHR $\$(12)$

5360 NEXT 1

5370 PRINT $¥ \%$, CHR $\$(12)$

5380 CLOSE $\# 2 A$ CLOSE $\# 1 \%$

5385 CLOSE"

S390 CHAIN "LGADER. BAS"

9000 PRINT \ PRINT "FILEUAME ' $\backslash$ INPUT NA\$

g005 PRINT HONE\$+CENTER \$+INNERSE末 + "READING " NA\$WNORMAL

9010 OPEN NAS FUR INPUT AS FILE $\$ 2 \%$

9030 INPUT * $*$ M,M REM NLMBER OF RECORDS IN FILE

9040 FOR N $1=0$ TON

9050 INPUT $* 2 \%,[A \$(N 1,0)$

3060 NEXT N1

9070 CLOSE $\neq 2 \%$

9075 PRINT HOME\$

9088 RETURN 
APPENDIX H. COMPUTER PROGRAMS TO REDUCE HPC TEMPERATURE DATA

LANGUAGE: FORTRAN-4

MACHINE: VAX 11/780 (Virtual Memory System)

INTRODUCTION - Two programs (DECAYI, FITTING1) have been developed to extrapolate temperature measured over time after penetration of a core barrel (HPC) into bottom sediments. These are presently written as separate programs, although they could be combined as subroutines called by a main program.

REFERENCE: $K$. Horai, A theory of processing downhole temperature data taken by the hydraulic piston corer (HPC) of the DSDP, ms. in preparation.

DECAY1 - Computes theoretical cooling temperature of an idealized core barrel in sediment, for the normalized initial temperatures of $1^{\circ} \mathrm{C}$ for the $\mathrm{HPC}$, and $0^{\circ} \mathrm{C}$ for the sediment. The core barrel is assumed to be a perfect conductor (uniform temperature) although with finite heat capacity, with 2-dimensional (radial) conduction to the sediment.

Instructions for running the program from a computer terminal

1. You will be asked by the terminal for values of $a$ and $b$; the inner and outer radii, respectively, of the HPC. The values of a and $b$ (units of meters) are typed in from the terminal.

2. Give a 6-digit file name to identify the cooling curve. If you give uvwxyz, the file name to be created will be Iuvwxyz. DAT.

3. Then you will be asked for the thermal conductivity of the sediment. Type in its value (units of $\mathrm{W} / \mathrm{mK}$ ).

4. Then you will be asked for the time interval between data points. Check the temperature record to be compared with the theory, and give it in the units of seconds.

5. The program computes 3500 terms of the integrand given in the theory (these are displayed on the terminal as computations progress) and 200 cooling temperatures at the specified time interval by numerically integrating the integrands, multiplied by an exponentially decaying term as given in the theory. The results are stored in the file.

FITTINGl - Compares the theoretical cooling curve with the temperature record to determine the optimal fit by least-squares analysis.

Instructions to run the program:

1. You will be asked for the 6-digit thermal decay file name. Type in from the terminal keyboard Tuvwxyz.DAT file. 
2. Then you will be asked for a 6-digit file name to specify the corresponding data. Type in from the terminal Dabcdef.DAT to open this data file.

3. Type in the number (IO) of "bad" (poorly fitting) data points (the first part of the cooling curve) that are not used in the analysis. Sometimes this must be done iteratively (trial and error) for noisy or otherwise uncertain data.

4. The printout will give the residual fit for various shift (NO) in origin of data points vs. theoretical curve. This is done to determine an effective origin time for uncertain penetrations. The data and the theoretical cooling temperatures will be printed for the value of NO that gives the minimum residual. 


\section{DOCUMENT LIBRARY}

April 9, 1985

\section{DISTRIBUTION LIST FOR TECHNICAL REPORT EXCHANGE}

Institute of Marine Sciences Library

University of Alaska

O'Neill Building

905 Koyukuk Ave., North

Fairbanks, AK

Attn: Stella Sanchez-Wade

Documents Section

Scripps Institution of Oceanography

Library, Mail Code C-075C

La Jolla, CA 92093

Hancock Library of Biology \& Oceanography

Alan Hancock Laboratory

University of Southern California

University Park

Los Angeles, CA 90089-0371

Gifts \& Exchanges

Library

Bedford Institute of Oceanography

P.O. Box 1006

Dartmouth, NS, B2Y 4A2, CANADA

Office of the International

Ice Patrol

c/o Coast Guard R \& D Center

Avery Point

Groton, CT 06340

Library

Physical Oceanographic Laboratory

Nova University

8000 N. Ocean Drive

Dania, FL 33304

NOAA/EDIS Miami Library Center 4301 Rickenbacker Causeway

Miami, FL 33149

Library

Skidaway Institute of Oceanography

P.O. Box 13687

Savannah, GA 31416

Institute of Geophysics

University of Hawaii

Library Room 252

2525 Correa Road

Honolulu, HI 96822
MIT Libraries

Serial Journal Room 14E-210

Cambridge, MA 02139

Director, Ralph M. Parsons Laboratory

Room 48-311

MIT

Cambridge, MA 02139

Marine Resources Information Center

Bldg. E38-320

MIT

Cambridge, MA 02139

Library

Lamont-Doherty Geological Observatory

Colombia University

Palisades, NY 10964

Library

Serials Department

Oregon State University

Corvallis, OR 97331

Pell Marine Science Library

University of Rhode Island

Narragansett Bay Campus

Narragansett, RI 02882

Working Collection

Texas A\&M University

Dept. of Oceanography

College Station, TX 77843

Library

Virginia Institute of Marine Science

Gloucester Point, VA 23062

Fisheries-Oceanography Library

151 Oceanography Teaching Bldg.

University of Washington

Seattle, WA 98195

Library

R.S.M.A.S.

University of Miami

4600 Rickenbacker Causeway

Miami, FL 33149

\section{Library}

Chesapeake Bay Institute 4800 Atwell Road

Shady Side, MD 20876 


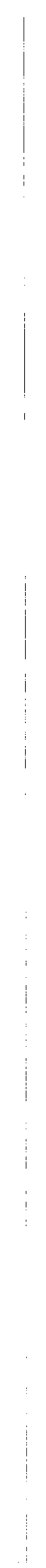




\begin{tabular}{|c|c|c|c|}
\hline $\begin{array}{l}\text { REPORT DOCUMENTATION } \\
\text { PAGE }\end{array}$ & $\begin{array}{l}\text { 1. REPORT NO. } \\
\text { WHOI-86-3 }\end{array}$ & 2. & 3. Reclpient's Accession No. \\
\hline \multirow{2}{*}{\multicolumn{3}{|c|}{$\begin{array}{l}\text { A Miniature Deep Sea Temperature Data Recorder: Design, Con- } \\
\text { struction, and Use }\end{array}$}} & $\begin{array}{l}\text { 5. Roport Date } \\
\text { January } 1986\end{array}$ \\
\hline & & & 6. \\
\hline \multicolumn{3}{|c|}{ Author(s) } & $\begin{array}{l}\text { 8. Pertorming Oryanization Ropt. No. } \\
\text { WHOI-86-3 }\end{array}$ \\
\hline \multirow{2}{*}{\multicolumn{3}{|c|}{$\begin{array}{l}\text { Performing Organization Name and Addrass } \\
\text { Woods Hole Oceanographic Institution } \\
\text { Woods Hole, Massachusetts } 02543\end{array}$}} & 10. Project/Task/Work Unit No. \\
\hline & & & $\begin{array}{l}\text { 11. Contract(C) or Grant(G) No. } \\
\text { (C) OCE 82-14658; } \\
\text { (G) OCE 83-00073 }\end{array}$ \\
\hline \multirow{2}{*}{\multicolumn{3}{|c|}{$\begin{array}{l}\text { 2. Sponsoring Orzenization Name and Address } \\
\text { National Science Foundation }\end{array}$}} & $\begin{array}{l}\text { 13. Type of Report \& Period Covered } \\
\text { Technical }\end{array}$ \\
\hline & & & 14. \\
\hline
\end{tabular}

5. Suppiementary Notes

This report should be cited as: Woods Hole Oceanog. Inst. Tech. Rept. WHOI-86-3.

5. Abstract (Limit: 200 words)

A miniature temperature recorder has been developed to be used with the hydraulic piston sediment corer (HPC) on the Deep Sea Drilling Project (DSDP). The instrumentation fits into pressure-sealed slots in the wall of the HPC, allowing temperature measurements to be made simultaneously with coring operations. Temperatures from -2 to $70^{\circ} \mathrm{C}$ are measured to a resolution of about $0.01^{\circ} \mathrm{C}$. Up to 130013 -bit measurements are recorded in random access memory (RAM), at a sampling rate ranging between $0.1 \mathrm{~s}$ to over $100 \mathrm{~min}$. , as specified by the operator in a program loaded into a microprocessor of the instrument. During recording the instrumentation uses about 3.5 mamp at 7.5 volts, which can be supplied for about 20 hours of operation by a custom-made pack of silver-oxide batteries. The corer is normally left motionless in the sediment for about $10 \mathrm{~min}$. to allow extrapolation of the measured temperatures to equilibrium in situ temperature. Examples of data from DSDP Leg 86 are given.

- Document Analysis: Descriptors

1. miniature temperature recorder

2. heat flow

3. drilling instrumentation

b. Identifiers/Open-Ended Terms

c. COSATI FIeId/Group

Availability Statemen:

Approved for publication; distribution unlimited.

19. Security Class (This Report)

UNCLASSIFIED

20. Security Closs (This Page)
21. No. of Pages 59

22. Price 


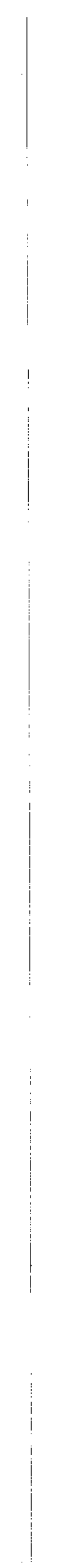

